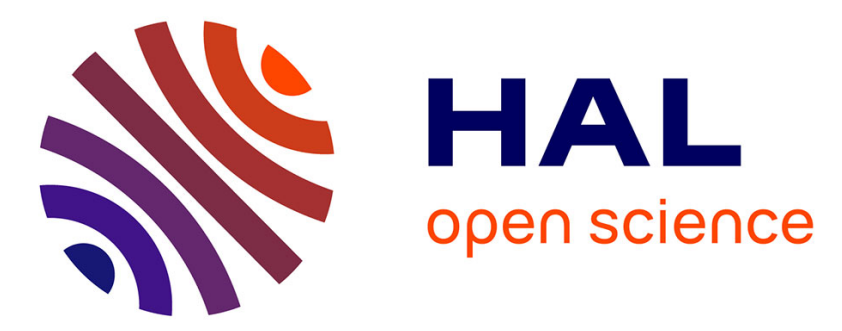

\title{
Controls on Gold Solubility in Arc Magmas: An Experimental Study at $1000^{\circ} \mathrm{C}$ and $4 \mathrm{kbar}$
}

Sébastien Jégo, Michel Pichavant, J.A. Mavrogenes

\section{To cite this version:}

Sébastien Jégo, Michel Pichavant, J.A. Mavrogenes. Controls on Gold Solubility in Arc Magmas: An Experimental Study at $1000^{\circ} \mathrm{C}$ and 4 kbar. Geochimica et Cosmochimica Acta, 2010, 74 (7), pp.2165-2189. 10.1016/j.gca.2010.01.012 . insu-00448303

\section{HAL Id: insu-00448303 \\ https://hal-insu.archives-ouvertes.fr/insu-00448303}

Submitted on 11 Apr 2011

HAL is a multi-disciplinary open access archive for the deposit and dissemination of scientific research documents, whether they are published or not. The documents may come from teaching and research institutions in France or abroad, or from public or private research centers.
L'archive ouverte pluridisciplinaire HAL, est destinée au dépôt et à la diffusion de documents scientifiques de niveau recherche, publiés ou non, émanant des établissements d'enseignement et de recherche français ou étrangers, des laboratoires publics ou privés. 


\title{
Controls on gold solubility in arc magmas: An experimental study at $1000{ }^{\circ} \mathrm{C}$ and 4 kbar
}

\author{
Sébastien Jégo ${ }^{\underline{a}} \underline{\mathbf{b}}$ Michel Pichavant ${ }^{\underline{b}}$ and John A. Mavrogenes ${ }^{\mathrm{c}}$ \\ ${ }^{a}$ Institute of Earth Sciences, Academia Sinica, 128 Academia Road, Sec. 2, Nankang, Taipei \\ 11529, Taiwan, Republic of China \\ ${ }^{\mathrm{b}}$ Institut des Sciences de la Terre d'Orléans (ISTO), CNRS: UMR6113, INSU, Université \\ d'Orléans, France \\ ${ }^{c}$ Research School of Earth Sciences, The Australian National University, Canberra, ACT \\ 0200, Australia
}

\begin{abstract}
In order to (1) explain the worldwide association between epithermal gold-coppermolybdenum deposits and arc magmas and (2) test the hypothesis that adakitic magmas would be $\mathrm{Au}$-specialized, we have determined the solubility of Au at $4 \mathrm{kbar}$ and $1000{ }^{\circ} \mathrm{C}$ for three intermediate magmas (two adakites and one calc-alkaline composition) from the Philippines. The experiments were performed over a $f \mathrm{O}_{2}$ range corresponding to reducing ( $\left.\sim \mathrm{NNO}-1\right)$, moderately oxidizing $(\approx \mathrm{NNO}+1.5)$ and strongly oxidizing ( $\sim \mathrm{NNO}+3)$ conditions as measured by solid Ni-Pd-O sensors. They were carried out in gold containers, the latter serving also as the source of gold, in presence of variable amounts of $\mathrm{H}_{2} \mathrm{O}$ and, in a few additional experiments, of $\mathrm{S}$. Concentrations of $\mathrm{Au}$ in glasses were determined by LA-ICPMS. Gold solubility in melt is very low (30-240 ppb) but increases with $f \mathrm{O}_{2}$ in a way consistent with the dissolution of gold as both $\mathrm{Au}^{1+}$ and $\mathrm{Au}^{3+}$ species. In the S-bearing experiments performed at $\sim \mathrm{NNO}-1$, gold solubility reaches much higher values, from $\sim 1200$ to $4300 \mathrm{ppb}$, and seems to correlate with melt $\mathrm{S}$ content. No systematic difference in gold solubility is observed between the adakitic and the non-adakitic compositions investigated. Oxygen fugacity and the sulfur concentration in melt are the main parameters controlling the incorporation and concentration of gold in magmas. Certain adakitic and non-adakitic magmas have high $f \mathrm{O}_{2}$ and magmatic $\mathrm{S}$ concentrations favorable to the incorporation and transport of gold. Therefore, the cause of a particular association between some arc magmas and $\mathrm{Au}-\mathrm{Cu}-\mathrm{Mo}$ deposits needs to be searched in the origin of those specialized magmas by involvement of $\mathrm{Au}$ - and S-rich protoliths. The subducted slab, which contains metal-rich massive sulfides, may constitute a potentially favorable protolith for the genesis of magmas specialized with respect to gold.
\end{abstract}

\section{Introduction}

There is general agreement that epithermal and porphyry-type deposits result from a combination of magmatic and hydrothermal processes ([Hedenquist and Lowenstern, 1994], [White and Hedenquist, 1990] and [White and Hedenquist, 1995]). On a worldwide scale, epithermal and porphyry-type deposits are spatially and temporally associated with magmatic intrusions ([Ulrich et al., 1999], [Halter et al., 2002], [Sillitoe, 1989], [Sillitoe, 1997] and [Sillitoe and Bonham, 1990]). Magma bodies may chemically contribute to the mineralizing systems by supplying elements which, upon volatile exsolution, are transferred into the magmatic-hydrothermal fluid phase. Certain components of hydrothermal fluids such as 
halogens and sulfur originate from magmatic sources (Hattori and Keith, 2001). However, the origin of metals $(\mathrm{Au}, \mathrm{Ag}, \mathrm{Cu}, \mathrm{Mo})$ in epithermal and porphyry-type deposits has long been a subject of debate, with metallogenic models dividing in essentially two groups. One group of models considers that metals originate in country rocks (e.g., [Keays and Skinner, 1989] and [Mathur et al., 2000]). In a second group of models, magmatic intrusions constitute the source of metals. These can be pre-concentrated through igneous differentiation processes, before being transferred to the magmatic-hydrothermal fluid phase ([Ulrich et al., 1999], [Halter et al., 2002] and [Harris et al., 2003]). In this paper, we use an experimental approach to explore the hypothesis that certain classes of magmas have the ability to pre-concentrate $\mathrm{Au}$ at the magmatic stage and, therefore, represent Au-enriched magmas.

A correlation between ore-forming processes and magma chemistry has been noted many times. $\mathrm{Cu}-\mathrm{Mo}$ deposits are commonly associated with oxidized magnetite-bearing magmas ([Ishihara, 1981] and [Blevin and Chappell, 1992]), and $\mathrm{Au}-\mathrm{Cu}$ deposits with potassic calkalkaline rocks and shoshonites (Müller and Groves, 1993). The existence of a link between economic deposits and alkaline arc magmas has been demonstrated in Papua-New Guinea (Richards, 1990). In other cases, a preferential relationship has been noted between adakitic magmatism and $\mathrm{Au}-\mathrm{Ag}-\mathrm{Cu}-\mathrm{Mo}$ epithermal and porphyry deposits ([Baldwin and Pearce, 1982], [Thiéblemont et al., 1997], [Sajona and Maury, 1998], [Gonzalez-Partida et al., 2003], [Levresse et al., 2004] and [Rae et al., 2004]), although such an association remains doubtful to some authors (e.g., Richards and Kerrich, 2007). The origin of a potential connection between adakitic magmas and epithermal and porphyry-type deposits is the central question addressed in this paper. We approach the problem by providing experimental Au solubility data in representative arc magmas. The experimental results allow the transport properties for $\mathrm{Au}$ of adakitic and non-adakitic magmas to be compared. They also place constraints on mechanisms of Au complexation in hydrous magmatic liquids of intermediate composition, typical of arc settings. The critical importance of oxygen fugacity $\left(f \mathrm{O}_{2}\right)$ and the presence of sulfur on Au transport in magmas are emphasized.

\section{Starting materials and experimental strategy}

\subsection{Starting materials}

Our experiments were performed in parallel on three natural samples, respectively representative of a typical adakite (Bal2), an intermediate adakite (Pin Dac) and a typical calcalkaline magma (PhM5) after the definition of Jego et al. (2005; see below), all from the North Luzon arc, Philippines (Fig. 1a; bulk rock compositions in Table 1). Recent (<20 Ma) magmatism in the North Luzon arc is linked to the current subduction of the South China Sea plate along the Manila Trench, and includes a range of arc rocks ([Sajona and Maury, 1998], [Prouteau et al., 2000], [Yumul et al., 2000], [Bellon and Yumul, 2001] and [Jego et al., 2005]). World-class $\mathrm{Cu}-\mathrm{Au}$ deposits are spatially and temporally associated with this recent magmatic activity, as shown by the chain of porphyry copper deposits extending from Dizon in the south to Lepanto in the north, and the epithermal Au deposits from the Baguio district ([Bellon and Yumul, 2000], Imai, 2001 A. Imai, Generation and evolution of ore fluids for porphyry $\mathrm{Cu}-\mathrm{Au}$ mineralization of the Santo Tomas II (Philex) deposit, Philippines, Res. Geol. 51 (2001), pp. 71-96. [Imai, 2001] and [Imai, 2002]; Fig. 1a). In the Baguio district, there is an intimate association between intrusive rocks and mineralization (Santo Tomas II $\mathrm{Cu}-\mathrm{Au}$ porphyry and Antamok and Acupan epithermal Au deposits, [Imai, 2001], [Imai, 2002] and [Polve et al., 2007]). The three starting rocks selected all come from this recent North Luzon magmatism. They have ages $<3$ Ma (Table 1). Diorite PhM5 comes from the Santo Tomas II 
(Philex) underground mine (Imai, 2001). Dacite Pin Dac is the white pumice erupted from Mt. Pinatubo in 1991, this volcanic system being considered analogous to plutonic systems related to $\mathrm{Cu}-\mathrm{Au}$ mineralization elsewhere in the North Luzon arc ([Imai et al., 1996] and [Imai, 2002]). Diorite Bal2 comes from a small intrusive plug located near Balungao (see Fig. 1a) and surrounded by hot springs and epithermal mineralization. Note that, with respect to the Manila Trench, Mt. Pinatubo is located in the main volcanic arc, called West Volcanic Chain (WVC), whereas Balungao is in a back-arc position, i.e., the East Volcanic Chain (EVC).

The three starting samples have intermediate $\mathrm{SiO}_{2}$ contents, within a narrow range (61.5 to $64.5 \mathrm{wt} \%$, Table 1). The other major oxides differ slightly between samples: Bal2 is the richest in $\mathrm{MgO}$, whereas $\mathrm{PhM} 5$ is slightly richer in $\mathrm{CaO}$ and $\mathrm{Fe}_{2} \mathrm{O}_{3}$, but poorer in $\mathrm{K}_{2} \mathrm{O}$ than the others. Thus, $\mathrm{CaO} / \mathrm{K}_{2} \mathrm{O}$ is three times greater in the non-adakitic (PhM5) than in the two adakitic samples (Bal2 and Pin Dac). The trace element contents are typical of arc magmas (Table 1): Large Ion Lithophile Elements (LILE) and Light Rare Earth Elements (LREE) are both enriched while High Field Strength Elements (HFSE) and Heavy REE (HREE) are depleted (Fig. 1b). However, the trace element patterns of the three samples are different in detail. The HREE and yttrium (Y) contents are much lower in the two adakites than in the non-adakite, consistent with the fractionation of these elements by garnet and amphibole during adakite genesis (e.g., [Defant and Drummond, 1990] and [Sen and Dunn, 1994]). For example, $\mathrm{Sr} / \mathrm{Y}$ ratios range between 20.8 and 197.8 (Table 1), which corresponds to a progressive transition from typical calc-alkaline magmas (PhM5) to adakites (Pin Dac then Bal2). According to Jego et al. (2005), adakitic rocks in island arc settings may be subdivided into two groups: (1) "typical" adakites (scarce; like Bal2) which exhibit primitive mantlenormalized HREE and Y contents around 1 or lower; (2) "intermediate" adakites (common; like Pin Dac) which display HREE and Y concentrations between 2 and 5 times the primitive mantle values. Those authors proposed that the most likely origin of "typical" adakites in arc settings is the hydrous partial melting, at minimum depth of $100 \mathrm{~km}$, of altered oceanic metabasalts converted to eclogite; a possible alternative hypothesis is the high-pressure fractionation (uppermost mantle) of garnet plus amphibole at the expense of mafic melts. "Intermediate" adakites, on the other hand, are believed to originate for most of them through magma mixing between slab-derived "typical" adakitic magmas and mafic mantle-derived ones, with an additional contribution of mantle in many cases (e.g., by assimilation). Also, the intervention of low degrees of partial melting of adakite-metasomatized mantle cannot be excluded, either in the genesis of some "intermediate" adakites, or in that of the mafic precursors from which they might derive through low pressure crystal fractionation or AFC.

Sulfur contents in starting materials (double-melting glass; see Section 3.1) are below the detection limits of the EPMA apparatus (see Section 3.4.1), i.e., less than $30 \mathrm{ppm}$. There is no previous published data on the sulfur content of PhM5 and Bal2, but sulfur in Pin Dac has been extensively studied (e.g., [Westrich and Gerlach, 1992], [Wallace and Gerlach, 1994], [Gerlach et al., 1996], [Kress, 1997], [Hattori and Keith, 2001] and [Borisova et al., 2006]). About 80-90 ppm S are reported in Pin Dac rhyolitic melt inclusions and $\approx 60-90$ ppm S in the rhyolite matrix glass. The bulk dacite pumice, though, contains as much as $1361 \pm 588$ ppm S, with maximum concentrations up to $2200 \mathrm{ppm} \mathrm{S}$ ([Bernard et al., 1991] and [Bernard et al., 1996]). These variable S contents in dacite pumices are explained by secondary alteration of magmatic anhydrite. Sulfur concentrations measured in our starting materials are very low, about three times lower than in the rhyolite matrix. Besides the fact that we avoided including anhydrite phenocrysts in the starting sample powder, such low $\mathrm{S}$ contents must be due to volatilization and loss of sulfur during double melting of the starting rock powder at $1400{ }^{\circ} \mathrm{C}$ in air. Anyway, less than $30 \mathrm{ppm} \mathrm{S}$ in melt are unexpected to form 
significant $\mathrm{Au}-\mathrm{S}$ complexes under the experimental conditions. Thus the experiments performed without addition of sulfur will be labeled "S-free" experiments throughout this study, as opposed to "S-added" runs.

The bulk gold contents of our samples are quite low (12-38 ppb; Table 1), close to the detection limits (which are generally $\leqslant 10 \mathrm{ppb}$ ) of the analytical equipment used (ICP-MS, Toulouse, France); these Au concentrations are in the same range as those measured by Borisova et al. (2006) in the rhyolitic matrix glass of the Pinatubo 1991 white dacite $(22 \pm 8 \mathrm{ppb})$. Note that the typical adakite Bal2 is the most Au-enriched.

\subsection{Experimental strategy}

The aim of this study is to determine the solubility of Au in adakitic and non-adakitic melts, in order to quantitatively evaluate their respective transport properties for $\mathrm{Au}$ at the magmatic stage (i.e., as opposed to the hydrothermal stage). Previously, the dependence of gold solubility with $f \mathrm{O}_{2}$ has been determined at 1 atm for a haplobasaltic (anorthite-diopside) composition ([Borisov and Palme, 1996] and [Borisov and Palme, 2000]). Solubilities of noble metals, including gold, were measured in basaltic liquids saturated with sulfides and sulfates at $1300{ }^{\circ} \mathrm{C}$ and $10 \mathrm{kbar}$ (Jugo et al., 2005). Several other studies have focused on the partitioning of $\mathrm{Au}$ between either silicic or mafic melt, vapour, brine, and condensed phases such as magnetite and sulfides ([Bezmen et al., 1994], [Fleet et al., 1996], [Fleet et al., 1999], [Crocket et al., 1997], [Jugo et al., 1999], [Frank et al., 2002], [Simon et al., 2003], [Simon et al., 2005] and [Simon et al., 2007]). Therefore, no Au solubility data is presently available at magmatic conditions for intermediate melts typical of mineralizing systems in arc settings.

To simulate conditions of evolution of intermediate arc melts as closely as possible in the experiments, a pressure of $4 \mathrm{kbar}$ was chosen and an elevated temperature $\left(100{ }^{\circ} \mathrm{C}\right)$, close to or above the liquidus of dacitic compositions such as the three starting rocks (e.g., Prouteau and Scaillet, 2003), was adopted. Hydrous conditions were imposed, the liquidus temperature allowing the concentration of $\mathrm{H}_{2} \mathrm{O}$ in melt to be varied without inducing significant crystallization of silicate phases. Control of redox state is a necessity in metal solubility studies (e.g., [O’Neill et al., 1995] and [Borisov and Palme, 1996]) and $f \mathrm{O}_{2}$ was varied from relatively reducing ( $\sim \mathrm{NNO}-1$, where $\mathrm{NNO}$ is the $\mathrm{fO}_{2}$ of the nickel-nickel oxide oxygen buffer at $P$ and $T$ ), moderately oxidizing ( $\sim \mathrm{NNO}+1.5$ ) to highly oxidizing ( $\sim \mathrm{NNO}+3$ ) conditions, in a range encompassing the $f \mathrm{O}_{2}$ of arc magmas. In addition to the main experimental parameters in this study (melt composition, $f \mathrm{O}_{2}$, melt $\mathrm{H}_{2} \mathrm{O}$ concentration or $a \mathrm{H}_{2} \mathrm{O}$ ), a few experiments were performed with addition of $\mathrm{S}$ to explore the effect of sulfur saturation on Au solubility.

\section{Experimental and analytical methods}

\subsection{Experimental charges}

Each of the three natural samples was ground in an agate mortar, then placed in a Pt crucible and fused at $1400{ }^{\circ} \mathrm{C}, 1 \mathrm{bar}$, in air for $4 \mathrm{~h}$. Two cycles of melting were performed to produce chemically homogeneous glasses which then were crushed. About $30 \mathrm{mg}$ of glass powder was loaded in pure gold capsules ( $2.5 \mathrm{~mm}$ ID, $2.9 \mathrm{~mm} \mathrm{OD}, 15 \mathrm{~mm}$ length) together with variable amounts of deionized water (between 5 and $10 \mathrm{wt} \%$ of the total charge), depending on the desired melt water content. Therefore, the container capsule served as the source of Au. For the S-bearing experiments, about $1 \mathrm{wt} \%$ of pure elemental sulfur $(\mathrm{S})$ was added to the charge. 
The experimental capsules were welded shut with a graphite arc-welder, and then stored in an oven at $110^{\circ} \mathrm{C}$ to ensure a homogeneous water distribution.

It is worth stressing that it has previously been shown experimentally ([Chou, 1986], [Gunter et al., 1987], [Linnen et al., 1995] and [Truckenbrodt and Johannes, 1999]) that hydrogen is largely permeable through Au-capsules at temperatures exceeding $800^{\circ} \mathrm{C}$, allowing us to easily control the redox state of our experimental charges. Other recent studies ([Scaillet et al., 1992] and [Schmidt et al., 1997]) even calculated the time required to reach $f \mathrm{H}_{2}$ equilibrium between the $\mathrm{Ar}-\mathrm{H}_{2}$ gas of a high-pressure vessel and the interior of $\mathrm{Au}$-capsules (= less than 10 minutes in the case of NNO and CCO buffer assemblages), while Dall'Agnol et al. (1999) preferred to use $\mathrm{Au}$-capsules at reducing conditions because $\mathrm{Fe}$ loss to $\mathrm{Au}$ is minimized and $\mathrm{Au}$ is sufficiently permeable to $\mathrm{H}_{2}$ above $700{ }^{\circ} \mathrm{C}$. Moreover, several previous studies using the solid sensor technique (see below) used alternatively Pt- and Au-capsules as container for the sensor, without any difference (e.g., [Scaillet and Evans, 1999], [Martel et al., 1999], [Pichavant et al., 2002] and [Clemente et al., 2004]). Therefore, hydrogen diffusion through $\mathrm{Au}$ is not a limiting factor in our experiments.

\section{2. $\mathrm{fO}_{2}$ sensors}

Experimental redox conditions were determined by the solid sensor technique ([Taylor et al., 1992] and [Pownceby and O'Neill, 1994]). The sensor assemblage consisted of a mixture of $\mathrm{M}+\mathrm{Pd}$ metal powders in variable proportions, plus metal-oxide (MO). For experiments above NNO buffer, $\mathrm{Ni}-\mathrm{Pd}$ metallic alloys $+\mathrm{NiO}$ metal-oxide were used (i.e., $\mathrm{M}=\mathrm{Ni}$ ), and for experiments below NNO buffer, $\mathrm{Co}-\mathrm{Pd}+\mathrm{CoO}$ mixtures $(\mathrm{M}=\mathrm{Co})$. For each experiment, two pellets of the appropriate sensor assemblage were prepared, with respectively a high and low $\mathrm{M} / \mathrm{Pd}$ ratio. These were loaded in a $20 \mathrm{~mm}$ length Pt capsule containing $\sim 10 \mathrm{mg}$ of deionized water, lined with $\mathrm{ZrO}_{2}$ powder to prevent alloying between the pellets and the capsule walls. The sensor Pt capsule was welded shut, and stored for $24 \mathrm{~h}$ in an oven at $110^{\circ} \mathrm{C}$ before being placed in contact with the experimental Au-capsules inside a thin alumina tube sample holder.

\subsection{Experimental equipment and procedure}

All experiments were performed at $400 \mathrm{MPa}$ and $1000^{\circ} \mathrm{C}$ in a vertical internally heated pressure vessel (IHPV). Either a molybdenum or a kanthal double-resistance furnace was used, allowing the 4-6 cm hot spot zone to be focused at the level of the sample holder.

Temperature was measured by two sheathed chromel-alumel thermocouples, calibrated at $1 \mathrm{~atm}$ against the melting point of $\mathrm{NaCl}\left(800.5^{\circ} \mathrm{C}\right)$, and is considered known to within $\pm 5^{\circ} \mathrm{C}$. Total pressure was monitored by a factory-calibrated Heise gauge, accurate to within 20 bar. Redox conditions were imposed and controlled by the $f \mathrm{H}_{2}$ prevailing in the pressure vessel. The IHPV was pressurized with either pure Ar gas or a mixture of $\mathrm{Ar}$ and $\mathrm{H}_{2}$ gases. In the case of pure Ar pressure medium, the intrinsic $f \mathrm{H}_{2}$ of the vessel is extremely low and imposes a very high $\mathrm{fO}_{2}\left(\log f \mathrm{O}_{2} \sim \mathrm{NNO}+3.4\right)$ when calculated under water-saturated conditions (i.e., $a \mathrm{H}_{2} \mathrm{O}=1$ ). To impose more reducing experimental conditions, $\mathrm{Ar}-\mathrm{H}_{2}$ mixtures generated by sequential loading of $\mathrm{H}_{2}$ and $\mathrm{Ar}$ were used (see Scaillet et al., 1995, for additional details). Experimental redox conditions corresponding to $\log f \mathrm{O}_{2}$ of the order of $\mathrm{NNO}+1$ and $\mathrm{NNO}-1$ were obtained by loading respectively about 1.5 and 15 bar of $\mathrm{H}_{2}$ gas in the vessel before $\mathrm{Ar}$ pressurization and heating (i.e., at ambient $P$ and $T$ ). The $f \mathrm{H}_{2}$ values mentioned in Table 2 and Table 3 correspond to experimental hydrogen pressures calculated from the $f \mathrm{O}_{2}$ of the final products. The experiments were rapidly-quenched by electrically melting the Pt wire that suspended the sample holder in the vessel hot spot zone ([Roux and Lefèvre, 1992] and [Di 
Carlo et al., 2006]). This caused the sample holder to drop to the cold end of the vessel with quench rates of the order of $300{ }^{\circ} \mathrm{C} / \mathrm{s}$. The duration of the runs was generally between 100 and $120 \mathrm{~h}$. We show below that such durations are sufficient to produce experimental glasses with homogeneous equilibrated Au concentrations.

\subsection{Analytical methods}

After each experiment, the capsules were checked for leaks by weighing, then opened, and the experimental products were prepared for analysis.

\subsubsection{Major and minor elements}

Glass fragments were mounted in epoxy, polished successively to a final diamond grit of $1 \mu \mathrm{m}$, and coated with a $\sim 0.03 \mu \mathrm{m}$ carbon film by using a standard thermal evaporation technique. Experimental glasses were analyzed for major elements with a Cameca SX50 electron microprobe (BRGM-CNRS facility, Orléans) equipped with five spectrometers. All data were obtained using $15 \mathrm{kV}$ acceleration voltage, $6 \mathrm{nA}$ beam current, a defocused electron beam ( $10 \mu \mathrm{m}$ diameter) and peak counting times of $10 \mathrm{~s}$. Multiple measurements were made for each sample ( $\sim 10$ analyses) to increase analytical accuracy and check for the chemical homogeneity of the glasses. Natural reference minerals (albite, anhydrite and hematite) were used as standards. To minimize the effect of migration of the alkalis $(\mathrm{Na}, \mathrm{K})$ in these hydrated glasses, the measured concentrations were adjusted by applying correction factors for volatilization determined from the analysis of the anhydrous starting glasses, taken as reference. Given that peak counting times and analytical conditions were kept the same for all charges (including starting materials), the correction factors were calculated as a function of the glass $\mathrm{H}_{2} \mathrm{O}$ content for a given melt composition. The composition of silicate mineral phases present in some experimental charges (mostly clinopyroxene) was determined as above and using a focused electron beam ( $\sim 1 \mu \mathrm{m}$ diameter).

The major element composition of oxide (magnetite) and sulfide (pyrrhotite) mineral phases was determined using $15 \mathrm{kV}$ acceleration voltage, $20 \mathrm{nA}$ beam current, a focused electron beam $(\sim 1 \mu \mathrm{m}$ diameter) and peak counting times of $10 \mathrm{~s}$. Hematite, pyrrhotite, anhydrite and pure metals were used as standards. We also tried to detect $\mathrm{Au}$ as a minor component in those oxides and sulfides. A counting time of $30 \mathrm{~s}$ and a beam current as high as $250 \mathrm{nA}$ were tested to reduce the limit of detection for Au. Although a detection limit as low as $330 \mathrm{ppm}$ (calculations after Ancey et al., 1978) was obtained, no trace of Au was found. Attempts were also made to analyze the Au-nuggets (see below). However, due to their small size, only partial analyses were obtained, confirming the presence of $\mathrm{Au}$ in major amounts.

Sulfur in starting materials (double-melting glasses) was measured by EPMA (JEOL JXA8500 F) in Taipei, Taiwan (IES-AS facility). Sulfur contents were always found to be below the detection limit (Table 1), even by using $15 \mathrm{kV}$ acceleration voltage, $50 \mathrm{nA}$ beam current, defocused electron beam (10 $\mu \mathrm{m}$ diameter) and peak counting times as long as $500 \mathrm{~s}$. Such analytical parameters lower the limit of detection to less than $30 \mathrm{ppm} \mathrm{S}$ (calculated as three times the standard deviation of replicate measurements). Pyrite was used for calibration.

Sulfur in experimental glasses was analyzed with a Cameca Camebax electron microprobe (BRGM-CNRS facility, Orléans) equipped with four spectrometers. This equipment, contrary to the SX50 probe, allows us to determine the concentration of a given element with each of the four spectrometers, simultaneously, leading to more accurate results. The data were 
obtained using $15 \mathrm{kV}$ acceleration voltage, $50 \mathrm{nA}$ beam current, a defocused electron beam (10 $\mu \mathrm{m}$ diameter) and peak counting times of $10 \mathrm{~s}$. The detection limit corresponding to such analytical parameters is of the order of $80 \mathrm{ppm} \mathrm{S} \mathrm{(Clemente} \mathrm{et} \mathrm{al.,} \mathrm{2004).} \mathrm{The} \mathrm{S-added}$ experiments were all conducted at reducing redox conditions $\left(\log f \mathrm{O}_{2} \sim \mathrm{NNO}-1\right)$, and the resulting charges all show sulfide (pyrrhotite) crystals at equilibrium. Therefore, the proportion of sulfur occurring as $\mathrm{SO}_{4}$ is believed to be negligible. Thus, since the position of the $\mathrm{K} \alpha$ line is dependent on the valency of $\mathrm{S}$, only the position corresponding to $\mathrm{S}^{2-}$ was chosen. Three standard glasses were used for calibration, with respective sulfur contents of 750,1400 and $1900 \mathrm{ppm} \mathrm{S}$. The analysis of these glass standards during each analytical session allowed calibration of the sulfur concentration as a function of the measured X-ray counts.

The Cameca Camebax electron microprobe was also used for determining the composition of the solid sensors. The metals analyzed were $\mathrm{Ni}, \mathrm{Co}$ and $\mathrm{Pd}$, together with $\mathrm{Pt}, \mathrm{Fe}$ and $\mathrm{S}$ to control the absence of any contamination from the capsule. The data were obtained using $15 \mathrm{kV}$ acceleration voltage, $21.5 \mathrm{nA}$ beam current, a defocused electron beam $(10 \mu \mathrm{m}$ diameter) and peak counting times of $10 \mathrm{~s}$. Pyrrhotite and pure metals were used for calibration.

\subsection{2. $\mathrm{H}_{2} \mathrm{O}$ concentrations in experimental glasses}

$\mathrm{H}_{2} \mathrm{O}$ contents of experimental glasses were determined by a Karl-Fischer coulometric titration method (Westrich, 1987). The apparatus employed was a Mettler Toledo KF DL 32 coulometer. For each experimental charge, multiple (at least 3 ) measurements were made successively; their average and the corresponding standard deviation $( \pm 2 \sigma)$ are reported in Table 2 and Table 3. For each measurement, a 5-10 mg fragment of silicate glass was placed in a Pt crucible before being melted at $1300{ }^{\circ} \mathrm{C}$ in 5 minutes by an induction furnace. The amount of water vapour released from the silicate melt was then measured in the titration cell of the coulometer. The analytical error of this method, even for very low water contents, is of the order of $\pm 0.1 \mathrm{wt} \%$ ([Westrich, 1987], [Holtz et al., 1992], [Holtz et al., 1995], [Behrens, 1995] and [Behrens et al., 1996]). For crystal-bearing charges, the glass $\mathrm{H}_{2} \mathrm{O}$ concentration was calculated from the measured bulk value by substracting the amount of crystals present, estimated by mass balance (see below).

\subsubsection{Gold concentrations}

Gold contents in experimental glasses were determined using laser ablation ICP-MS system at the Research School of Earth Sciences (RSES) of the Australian National University (ANU, Canberra). This system consists of a Lambda Physik LPX 1201 pulsed ArF excimer laser coupled to a Agilent 7500 ICP-MS (Sun et al., 2003). NIST 612 was used as the external standard and the isotope 29 of $\mathrm{Si}\left({ }^{29} \mathrm{Si}\right)$ was used as an internal standard.

A representative LA-ICP-MS signal is shown in Fig. 2a. Each signal is constituted of a first part corresponding to the background (laser off), then a second part corresponding to the actual measurement (laser on). The ablation was performed by drilling; thus the hole drilled becomes progressively deeper with time. The data were obtained using $22 \mathrm{kV}$ acceleration potential, $120 \mathrm{~mJ}$ energy and a variable laser power from 0.6 to $1.3 \mathrm{~W}$. The diameter of the laser beam and the pulsation frequency were optimized to $40 \mu \mathrm{m}$ and $5 \mathrm{~Hz}$, respectively, during $60 \mathrm{~s}$, leading to a 20-25 $\mu \mathrm{m}$ depth hole. A background time half of the ablation time (i.e., 20 or $30 \mathrm{~s}$ ) was chosen. At least three analyses were made for each experimental charge 
to check for homogeneity. NIST 612 standard $(\mathrm{Au}=4.58 \mathrm{ppm}$; Sun et al., 2004) was used for calibration and the calculation of Au concentrations. Besides gold and other noble metals, tantalum (Ta) was analyzed because this element may interfere with $\mathrm{Au}$, following:

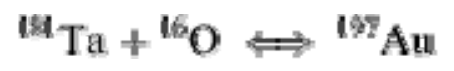

This interference was corrected based on the Ta concentrations; nevertheless, the difference between uncorrected and corrected results ranges from $-1 \%$ (some uncorrected values lying slightly below the corresponding corrected concentration) to $10 \%$, within the analytical errors (see supplementary information in Sun et al., 2004).

The limits of detection (LOD) for Au are shown in Tables 2 and 3 for each experimental charge. Each analytical point of every charge has its own LOD, although all analyses were conducted with the same laser beam diameter $(40 \mu \mathrm{m})$. Here, the detection limits were calculated as three times the standard deviation of three replicate measurements of the background noise (consistently representative of the analytical blank). Therefore, for a given analytical point, LOD may vary conversely to the width of the ablation signal used for the calculation of Au concentrations (see Fig. 2), relative to both standards and background. However, LOD are always significantly lower than measured glass gold concentrations. The $\mathrm{LOD} /[\mathrm{Au}]$ value ([Au] being the gold concentration in the glass) is up to $76 \%$ for one analytical point in charge $\mathrm{C} 2 \mathrm{~K}$. However, most charges have $\mathrm{LOD} /[\mathrm{Au}]$ in the range $0.02-$ $35 \%$. Moreover, the $\sigma /[\mathrm{Au}]$ values ( $\sigma$ being the standard deviation of n replicate measurements of glass gold content in one charge) are generally low, most of the experimental charges showing $\sigma /[\mathrm{Au}]$ values lower than or equal to $10 \%$. This demonstrates the high sensitivity of our gold concentration measurements and implies that gold is homogeneously distributed in our experimental glasses, a condition necessary for the attainment of equilibrium in the experiments. In run no. $11, \sigma /[\mathrm{Au}]$ values are higher (up to $32 \%$, charge $\mathrm{C} 4 \mathrm{~K}$ ), probably a consequence of the very low Au contents measured in those glasses (33 ppb in $\mathrm{C} 2 \mathrm{~K} ; 50 \mathrm{ppb}$ in charges $\mathrm{C} 3 \mathrm{~K}$ to $\mathrm{C} 6 \mathrm{~K}$ ).

Fig. 2a shows stable metal counts (major elements other than Fe are not shown) which are easily converted to concentrations in melt. Another common type of LA-ICP-MS signal (Fig. $2 b$ ) is characterized by the presence of several metal concentration spikes (including Fe, but $\mathrm{S}$ was not monitored). Depending on which metals were involved in the spikes, signals of this type were interpreted to occur when the laser beam meets sulfides (as in Fig. 2b) or Au-rich metal (mainly Pt, Cr, Ni) alloys (called Au-nuggets throughout this study) during drilling. Only flat parts of the ablation signals were considered to be representative of Au dissolved in glass and used for the calculation of melt Au concentrations.

\subsubsection{Analytical data processing}

For each charge, water activity $\left(a \mathrm{H}_{2} \mathrm{O}\right)$ was calculated from the $\mathrm{H}_{2} \mathrm{O}$ content and the major element (excluding S) composition of glass, using the model of Burnham (1979). Oxygen fugacity $\left(f \mathrm{O}_{2}\right.$, referenced to the NNO equilibrium, Pownceby and $\left.\mathrm{O}^{\prime} \mathrm{Neill}, 1994\right)$ was calculated from both experimental $f \mathrm{H}_{2}$ and $f \mathrm{H}_{2} \mathrm{O}$ (the latter obtained from $a \mathrm{H}_{2} \mathrm{O}$ ), following the water dissociation equilibrium:

(2) $f \mathrm{O}_{2}=\left(K_{\mathrm{w}} \cdot f \mathrm{H}_{2} \mathrm{O} / f \mathrm{H}_{2}\right)^{2}$ with $K_{\mathrm{w}}$ taken from Robie et al. (1978). Experimental $f \mathrm{H}_{2}$ was determined from the sensor capsule since $f \mathrm{O}_{2}$ is known from the composition of the alloy 
phase ([Taylor et al., 1992] and [Pownceby and O'Neill, 1994]) and $\mathrm{H}_{2} \mathrm{O}$ is present in excess (hence $f \mathrm{H}_{2} \mathrm{O}=f \mathrm{H}_{2} \mathrm{O}^{\circ}$ ). The $f \mathrm{O}_{2}$ is known to better than $0.25 \log$ units ([Scaillet et al., 1995] and [Martel et al., 1999]). For S-bearing charges, $f \mathrm{~S}_{2}$ was calculated from the composition of pyrrhotite (Froese and Gunter, 1976) and $f \mathrm{SO}_{2}$ and $f \mathrm{H}_{2} \mathrm{~S}$ by using the equilibrium constants of Ohmoto and Kerrick (1977).

The crystallinity of experimental charges was determined by mass balance, using the electron microprobe compositions of the starting glass and of all condensed phases present. The calculations were performed using a least-squares technique adapted from Albarède (1995) based on eight major oxides, excluding $\mathrm{MnO}$ and $\mathrm{H}_{2} \mathrm{O}$. Phase proportions were calculated together with bulk composition, and Fe loss was obtained from the difference between calculated and starting compositions.

\section{Results}

Results for a total of 27 charges, including $21 \mathrm{~S}$-free and $6 \mathrm{~S}$-added are reported. Experimental conditions and results for the sulfur-free and sulfur-added charges are summarized in Table 2 and Table 3, respectively.

\subsection{Experimental parameters $\left(a \mathrm{H}_{2} \mathrm{O}, f \mathrm{O}_{2}, f \mathrm{~S}_{2}\right)$}

$\mathrm{H}_{2} \mathrm{O}$ contents in S-free experimental glass range from 4.13 to $9.22 \mathrm{wt} \%$ (Table 2), with corresponding $a \mathrm{H}_{2} \mathrm{O}$ values ranging from 0.49 to saturation (i.e., $a \mathrm{H}_{2} \mathrm{O}=1$ ), the latter condition being attained in only a few charges (6 on 21). Melt $\mathrm{H}_{2} \mathrm{O}$ concentrations at saturation are close to $8 \mathrm{wt} \%$ (bracketed by charges C1B: $8.28 \mathrm{wt} \%$ and $\mathrm{C} 6 \mathrm{~K}: 7.60 \mathrm{wt} \%$ ). They differ little between the three investigated melts, in agreement with their similar major element compositions (Table 1). In the S-added charges, performed only with the Pin Dac composition, the $\mathrm{H}_{2} \mathrm{O}$ contents range between 5.86 to $8.03 \mathrm{wt} \%$ (Table 3). The latter concentration is identical to the water saturation found in S-free experiments on the same composition (compare charges $\mathrm{C} 1 \mathrm{E}$ and $\mathrm{C} 1 \mathrm{~F}$, Table 2 and Table 3). Thus, for the Pin Dac composition, maximum $\mathrm{H}_{2} \mathrm{O}$ concentrations in glasses are not significantly different in the sulphur-free and sulphur-added experiments.

Oxygen fugacity values in our S-free experimental glasses range from $\mathrm{NNO}-1.62$ to $\mathrm{NNO}+2.62$ (Table 2). A wide $\mathrm{fO}_{2}$ range has thus been investigated, encompassing different redox conditions: reducing (run 11) and moderately to highly oxidizing (runs 1, 2 and 10). The S-added experiments were all conducted in a reducing environment, leading to very homogeneous $f \mathrm{O}_{2}$ values (from NNO-1.26 to NNO-0.97, Table 3), and enabling comparison with the S-free experiment at nearly the same $f_{2}$. The calculated sulfur fugacity values (see Table 6) vary by more than one order of magnitude $\left(1.00<\log f \mathrm{~S}_{2}<2.03\right)$, while melt sulphur concentrations range from 548 to $957 \mathrm{ppm}$. Note that $f \mathrm{~S}_{2}$ in both charges C1E and C3E were estimated from their glass $\mathrm{S}$ concentrations, because pyrrhotite crystals large enough to be satisfactorily analyzed by electron microprobe were not found.

\subsection{Experimental products and compositions}

Charges in both sulfur-free and sulfur-added experiments comprise silicate glass and a small proportion - generally less than $5 \mathrm{wt} \%$ - of crystalline phases (silicates, oxides, sulfides, rare metallic phases, Table 2 and Table 3; see Fig. 3a for a texture typical of most of our run products). A vapour phase is considered to be present for $\mathrm{H}_{2} \mathrm{O}$-saturated charges, i.e., for 
charges with $a \mathrm{H}_{2} \mathrm{O}=1$ (Table 2). In the S-added experiments, a free fluid phase is also considered to be systematically present (i.e., the system at equilibrium is fluid-saturated), even if the melt is strictly-speaking $\mathrm{H}_{2} \mathrm{O}$-undersaturated $\left(a \mathrm{H}_{2} \mathrm{O}<1\right)$ in the experimental conditions: this is because $\mathrm{S}$ is relatively insoluble in silicate melts and systematically induces the formation of a S-rich vapour phase (containing mainly $\mathrm{H}_{2} \mathrm{~S}+\mathrm{SO}_{2}+\mathrm{S}_{2}+\mathrm{H}_{2} \mathrm{O}$ ) at equilibrium, whatever the $a \mathrm{H}_{2} \mathrm{O}$ calculated in the corresponding S-free system (from Burnham, 1979; see Section 3.4.4) may be. Then, the presence of a vapour phase leads to significant partitioning of all components from liquid to vapour, notably gold (e.g., [Ulrich et al., 1999], [Sun et al., 2004] and [Simon et al., 2007]). Given the amounts of $\mathrm{H}_{2} \mathrm{O}$ initially loaded in the capsules, this vapour phase is present in very low amounts $(<2-3 \mathrm{wt} \%$ of the total charge). Besides, the major part of the exsolved fluid phase was as a whole free out of the melt, i.e., not trapped into bubbles or fluid inclusions. Therefore, the gold concentrations obtained by ablating the melt quenched to glass are believed to truly reflect that in the melt, not the combined total of melt + fluid gold contents. It follows that the determination of gold in the fluid phase turned out to be technically difficult due to this quasi-absence of bubbles in our experimental products. This is one reason why we did not examine here the partitioning of gold between melt and fluid. Yet, we aim to stress that the main goal of the present study was not to examine the process controlling gold partitioning during volatile exsolution at the hydrothermal stage, which has already been much investigated ([Bezmen et al., 1994], [Fleet et al., 1996], [Fleet et al., 1999], [Crocket et al., 1997], [Jugo et al., 1999], [Frank et al., 2002], [Simon et al., 2003], [Simon et al., 2005] and [Simon et al., 2007]), but to focus on the solubility and transport of gold in melt at the magmatic stage.

Major element compositions of experimental glasses are given in Table 4. They are quite similar to their respective starting glass compositions, since the proportion of condensed phases is always very small in the run products. However, significant depletions in $\mathrm{CaO}, \mathrm{FeO}$, $\mathrm{MgO}$ and, to a lesser extent, $\mathrm{TiO}_{2}$, associated with enrichments in $\mathrm{Na}_{2} \mathrm{O}$, occur in some glasses, such as $\mathrm{C} 3 \mathrm{~A}$ (low $\mathrm{Ca}, \mathrm{Mg}$; high $\mathrm{Na}$ ) and $\mathrm{C} 4 \mathrm{~K}$ (low $\mathrm{Ca}, \mathrm{Mg}$, $\mathrm{Ti}$ ) when compared to the respective starting compositions (see Table 1). These chemical changes are consistent with fractionation of clinopyroxene (Cpx), as clearly shown for example by the correlation between the mass fraction of $\mathrm{Cpx}$ in charges $\mathrm{C} 1 \mathrm{~B}$ to $\mathrm{C} 3 \mathrm{~B}$ (run 2, composition Bal2, Table 2) and the magnitude of the depletions in the above oxides. Depletions in $\mathrm{FeO}$ in $\mathrm{S}$-free glasses are also observed without any association with Cpx fractionation (e.g., charges C5J-C6J, run 10, Table 2), and can be related to the crystallization of magnetite. Finally, charges of experiments 1,2 and 11 are characterized by systematic Fe losses $(7.8-8.9 \%$ in run $1 ; 2.2-$ $9.3 \%$ in run $2 ; 19.3-31.8 \%$ in run 11 ; see $\Delta \mathrm{FeO}$ values in Table 2 for details). Since these iron losses were determined by mass balance calculations between the starting compositions and our final experimental charges (glass + crystals), they indicate Fe alloying with $\mathrm{Au}$ from the capsule. The highest Fe losses are found in run 11 which is the most reduced. $\Delta \mathrm{FeO}$ values were not calculated for S-added charges since most of available Fe partitions from the melt to pyrrhotite crystals, preventing significant Fe alloying with capsule walls.

Silicate crystals present in both S-free and S-added experiments are diopside-rich clinopyroxenes (Table 5), with sizes mostly less than $20 \mu \mathrm{m}$ (Fig. 3a and b). Oxides are found only in the most oxidizing S-free experiment (run 10, Table 2); most have a size from $<1$ to a few $\mu \mathrm{m}$. Satisfactory electron microprobe analyses were obtained only for oxides from charge C6J (Fig. 3c; Table 2) and demonstrate that these oxide phases are magnetites (Table 5).

Sulfides have similar Fe/S atomic ratios, close to 1, implying that these sulfides are pyrrhotites $\left(\mathrm{Fe}_{1-x} \mathrm{~S}\right.$, with $0<x<0.2$; see Table 6). No evidence was found (from the 
composition of sulfides) for the presence of an immiscible $\mathrm{Fe}-\mathrm{S}-\mathrm{O}$ sulfide liquid under our experimental conditions.

Tiny spherical gold blebs (generally about $1 \mu \mathrm{m}$ in size, hereafter designated as gold nuggets) were commonly found spatially associated with magnetite in three charges of the most oxidizing experiment (run 10). Some Au-nuggets slightly larger in size were also found in close textural association with pyrrhotite (Table 3; Fig. 3d). Despite their common spherical shape, these gold particles are not thought to have passed by a liquid state during the experiment, since the melting point of $\mathrm{Au}$ at $1 \mathrm{bar}$ is close to $1060^{\circ} \mathrm{C}$. Simon et al. (2007) also reported the presence of Au-nuggets in their experimental charges from the analysis of their LA-ICP-MS ablation signals. However, the inferred particles were not directly observable, probably due to their sub-micron size, and Simon et al. (2007) considered these Au-nuggets to be quench phases. In contrast, our SEM observations (see Fig. 3d) suggest that the Au-nuggets in this study are phases stable at our experimental $P$ and $T$. Indeed, the Aunuggets are systematically associated with magnetite and pyrrhotite crystals, suggesting that their appearance is related to the oxide/sulfide crystallization mechanism. In addition, as illustrated by Fig. 3d, Au-nuggets in our experimental products can be as large as $\sim 10 \mu \mathrm{m}$ in diameter when in spatial association with sulphide crystals. Such grain sizes are unlikely for quench phases, especially considering the characteristics of the quench in this study (isobaric and very fast, lasting $<5 \mathrm{~s}$ ). Therefore, we interpret the nuggets as having formed at experimental $P$ and $T$ from a locally Au-saturated melt boundary layer generated during growth of oxides and sulfides. This interpretation provides the justification for not considering the Au spikes in the ICP-MS ablation signals for the calculation of the gold melt concentrations (see above, Fig. 2 and Section 3.4.3) since the nuggets were not formed during quench.

\subsection{Au concentrations in glasses}

Gold contents of sulfur-free and sulfur-added experimental glasses are presented in Table 2 and Table 3, respectively. Concentrations have been recalculated as mole fractions of $\mathrm{Au}$ dissolved in glass $\left(X_{\mathrm{Au}}\right)$ by using glass major element concentrations and water contents from Table 2, Table 3 and Table 4.

The distribution of the gold contents as a function of $f \mathrm{O}_{2}$ is shown in Fig. 4 for the S-free charges. Globally, the data show that Au concentrations increase with increasing $f \mathrm{O}_{2}$. For example, for Bal2, Au concentrations range from $50 \mathrm{ppb}$ under reducing conditions to $236 \mathrm{ppb}$ under oxidizing conditions (Fig. 4). In the same way, 50-55 ppb Au are dissolved in $\mathrm{PhM} 5$ at NNO-1.35, reaching $240 \mathrm{ppb}$ at around NNO+2.5. The evolution of Pin Dac gold contents is similar, with $33 \mathrm{ppb}$ Au for reducing conditions, steeply increasing to $237 \mathrm{ppb}$ at around $\mathrm{NNO}+2.5$. Overall, it is worth stressing that the increase in the gold concentration along the entire experimental $f \mathrm{O}_{2}$ range (which covers more than $4 \log$ units) is smaller than one order of magnitude. In comparison to the effect of $f \mathrm{O}_{2}$, there is no systematic influence of $a \mathrm{H}_{2} \mathrm{O}$ on the $\mathrm{Au}$ concentrations in glasses from the $\mathrm{S}$-free charges.

All three investigated samples show a maximum of gold solubility around $\approx 240 \mathrm{ppb}$ Au (Fig. 4) for the highest $f \mathrm{O}_{2}$. In contrast, at lower $f \mathrm{O}_{2}$, differences appear between the three starting compositions. In the middle of the $f \mathrm{O}_{2}$ range, Au concentrations for the Pin Dac melt composition are lower than for PhM5, these latter being lower than for Bal2. At low $\mathrm{fO}_{2}$, the composition with the lowest Au concentration is also Pin Dac. However, the Pin Dac 
experiment was carried out under lower $f \mathrm{O}_{2}$ (Fig. 4). Therefore, this minor difference in $\mathrm{Au}$ concentrations may be related to $\mathrm{fO}_{2}$.

The Au concentration data for the S-added charges with the Pin Dac sample are shown plotted on Fig. 5. Au concentrations are much higher in the S-added than in the S-free charges, ranging from 1200 to $4250 \mathrm{ppb}$. This corresponds to an increase of $\mathrm{Au}$ concentrations in glasses by factors of 25-85 in comparison with the S-free glasses in the same range of $f \mathrm{O}_{2}$. Thus, there is a dramatic increase (of more than one order of magnitude) of the concentration of gold in glasses when $\mathrm{S}$ is added at nearly constant $\mathrm{fO}_{2}$ (around $\mathrm{NNO}-1$ to -1.5 ). In detail, the $\mathrm{Au}$ concentrations for the S-added charges are strongly positively correlated with $\mathrm{fO}_{2}$ (Fig. 5 ), despite the narrow $f \mathrm{O}_{2}$ range ( $\Delta \mathrm{NNO}$ varies only from -0.97 to -1.26 , Table 3 ). However, it is worth noting that, in these S-added charges, the $f \mathrm{O}_{2}$ variation is obtained by changing the melt $\mathrm{H}_{2} \mathrm{O}$ content (or $a \mathrm{H}_{2} \mathrm{O}$, see Table 3). Therefore, in contrast with the S-free charges, the $\mathrm{S}$-added charges exhibit a clear positive correlation between their Au concentrations and their $a \mathrm{H}_{2} \mathrm{O}$ which simply reflects the fact that $a \mathrm{H}_{2} \mathrm{O}$ and $f \mathrm{O}_{2}$ are correlated in our experiments.

\section{Discussion}

\subsection{Attainment of equilibrium}

Electron microprobe analyses of experimental glasses and clinopyroxenes have standard deviations in most cases lower than analytical uncertainties (Table 4 and Table 5), indicating that these phases are homogeneous in terms of their major elements. Glasses in the S-added charges also have homogeneous sulphur concentrations. For gold, the statistics of the Au analyses, detailed above, imply that gold is homogeneously distributed in our experimental glasses. The ability of the melt to homogenize with respect to Au can be tested by considering the amount of time required for Au to diffuse through the melt at run conditions. Calculation of the diffusion distance of gold can be performed by assuming that the diffusivity of $\mathrm{Au}$ $\left(\right.$ taken as $\mathrm{Au}^{1+}$ ) is intermediate between that of the univalent metals $\mathrm{Na}$ and $\mathrm{Cs}$ (Simon et al., 2007). Thus, at $1000{ }^{\circ} \mathrm{C}$ and for $6 \mathrm{wt} \% \mathrm{H}_{2} \mathrm{O}$ in the melt, a gold diffusivity of $m 10^{-10} \mathrm{~m}^{2} / \mathrm{s}$ is obtained from Watson (1994). This yields a diffusion distance of $6 \mathrm{~mm}$ for experimental durations of $100 \mathrm{~h}$. Therefore, our experimental conditions (durations, temperature and melt $\mathrm{H}_{2} \mathrm{O}$ contents) and capsule geometries (see above) effectively enabled gold to be homogeneously distributed within the melts, even though a significant proportion of $\mathrm{Au}^{3+}$ is to be considered in the calculation. In addition, the attainment of equilibrium in our charges is strongly supported by the results of time-series runs performed by Bezmen et al. (1994) that show that gold equilibrates between sulfide and mafic/intermediate silicate melts after $30 \mathrm{~h}$ at $1250{ }^{\circ} \mathrm{C}$ and $4 \mathrm{kbar}$, for a silicate charge of $6 \mathrm{~mm}$ in diameter and $6 \mathrm{~mm}$ in height, weighing 300-350 mg (i.e., more than 10 times the weight of our silicate charges). For $\mathrm{H}_{2} \mathrm{O}$ in glasses, only bulk analytical data are available. However, multiple Karl-Fischer measurements were performed on each glass sample; standard deviations $( \pm 2 \sigma)$ are generally $<1 \%$, indicating homogeneity. Considering that glass powders were used as starting materials, the experimental durations in this study $(>100 \mathrm{~h})$ and the diffusivity data for of $\mathrm{H}_{2} \mathrm{O}$ in silicate melts of intermediate composition (Liu et al., 2004), water is certainly distributed homogeneously in the experimental glasses. Therefore, we conclude that our experimental phases are chemically homogeneous, a condition necessary for equilibrium.

Nevertheless, it is worth emphasizing that all experimental glasses in this study attained their final gold concentrations from the low concentration side since gold concentrations in starting materials are lower than in experimental glasses. Gold solubility was in no case approached 
from the high concentration side. Thus, our Au concentration data have not been reversed. Yet, various lines of evidence, detailed below, suggest that the Au concentrations measured in the glasses can be considered as equilibrium solubilities at high $P$ and $T$. (1) Gold concentrations in the experimental glasses from this study vary by more than two orders of magnitude, ranging from 33 to $4253 \mathrm{ppb}$ (Table 2 and Table 3). Gold concentrations in glasses correlate with the experimental parameters and with melt composition (Fig. 4), so that the variations in gold concentrations between samples can be ascribed to differences either in $f \mathrm{O}_{2}$, presence/absence of $\mathrm{S}$ or melt composition. This would be unexpected if Au concentrations in glasses were influenced by kinetic factors. Nevertheless, it is true that those parameters $\left(f \mathrm{O}_{2}\right.$, $f \mathrm{~S}_{2}$, composition) are also often incorporated into the equilibrium constant and then, they may potentially exert a control on the kinetics of reactions. There are no data in the literature which constrain the effect of such parameters on the diffusion rate of gold; however - for example - Watson (1994) reports a relatively small $f^{\mathrm{O}_{2}}$ effect on the diffusion rate of sulfur, implying that the diffusing species and/or diffusion mechanism is relatively independent of $\mathrm{fO}_{2}$. In fact, it can be assumed that those parameters might have a significant effect on the diffusion rate of gold during the first few hours of an experiment - i.e., well before the attainment of equilibrium - but they are very unlikely to be the cause of the observed correlations after more than $100 \mathrm{~h}$. (2) Duplicate experiments were performed to check for reproducibility. Run no. 6 is a duplicate of run no. 5 (Table 3). Gold solubilities in these two experiments are mutually consistent and the results stress the direct dependence of gold solubilities with glass $\mathrm{S}$ concentrations (the high standard deviation of the $\mathrm{S}$ measurements in glass $\mathrm{C} 1 \mathrm{E}$ is due to an unusually slow quench of the run no. 5, see Table 3). (3) In this study, a fast quench device was used systematically. The Au-nuggets present in some charges correspond to stable phases present at experimental $P-T$ conditions and not to phases precipitated during quench. Therefore, the gold concentration of the melt did not suffer any modification during quench, implying that the Au concentration data reported unambiguously concern gold concentrations in the melts at high $P$ and $T$.

\subsection{Influence of $\mathrm{fO}_{2}$ on the solubility of gold}

\subsubsection{Thermodynamic analysis of the solubility of Au in silicate melts}

The dissolution of a given trace metal, here $\mathrm{Au}$, in a silicate liquid can be expressed by the following equilibrium (e.g., O’Neill et al., 1995):

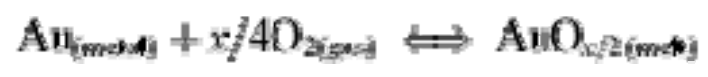

where $\mathrm{AuO}_{\mathrm{x} / 2 \text { (melt) }}$ stands for the metal species dissolved in the silicate melt, and $x$ represents the effective valence of the dissolved metal species. The value of $x$ is not necessarily an integer, since the metal dissolution mechanism may imply several metal species with different valences. A special case not usually considered, but which might become important for gold, is if $x=0$, i.e., gold dissolves as a neutral species. The equilibrium constant $\left(K_{\mathrm{Au}}\right)$ corresponding to Eq. (3) at constant temperature and pressure can be written as:

$$
\begin{aligned}
& \log K_{\text {Am }}=\log \left(X_{\text {Am }}^{\text {mad }} \cdot \gamma_{\text {Am }}^{\text {mats }}\right) \\
& -\log \left(X_{\text {Am }}^{\text {mat }} \cdot \gamma_{A m}^{\circ}\right)+x / 4 \log f \mathrm{O}_{2}
\end{aligned}
$$




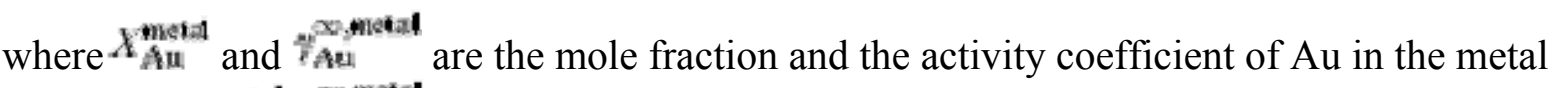

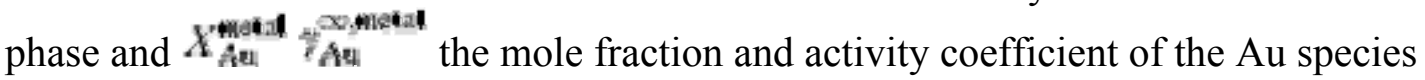
dissolved in the melt. In our experiments, melts were equilibrated with pure gold metal. Therefore, the activity and the mole fraction of gold in the metal can be taken equal to unity. Note that this assumption does not necessarily apply in the case of the most reduced charges where alloying of Fe with Au from the capsule takes place. However, in this study, no correction has been introduced to account for the reduction of the concentration of $\mathrm{Au}$ in the metal phase that results from alloying with Fe. Thus it follows that:

\section{$\log X_{r m}^{\text {mat }}=x / 4 \log f \mathrm{O}_{2}-\log K_{\text {Mm }}$

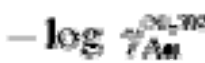

At given temperature $T$ and pressure $P, \log K_{\mathrm{Au}}$ is constant. If we assume that $\log$ is independent of the concentration of metal dissolved in the melt, and of $f \mathrm{O}_{2}$ and $\mathrm{T}$ (but not necessarily of the melt composition), it follows that:

$\log X_{\text {mat }}^{\text {mati }}=x / 4 \log f \mathrm{O}_{2}+C$

where $\mathrm{C}=-\log K_{\mathrm{Au}}-\log \gamma_{\mathrm{Au}}^{\text {and }}$ (thus $\mathrm{C}$ is constant for a given melt composition). Eq. (6) is the basic relation used in this study for the interpretation of the experimental results. Note that the hypothesis of $\log ($ Ar $)$ being independent of the metal concentration in the melt is equivalent to assuming that metal dissolution follows Henry's law for our investigated ranges of metal concentration, $T$ and $f \mathrm{O}_{2}$.

\subsubsection{Gold solubility mechanism}

Eq. (6) implies that, at a given temperature, metal solubility is linearly related to $f \mathrm{O}_{2}$, with a slope equal to $x / 4$. Thus, the valence of a metal dissolved in a silicate melt $(x)$ may be determined from the slope of the dependence of $\log X_{\text {Alt }}$ with $\log f \mathrm{O}_{2}$. For S-free charges, in the oxidizing part of the diagram (above $\mathrm{NNO}+1.5$ in Fig. 6a), linear fits to the solubility data (all compositions taken together) yield a slope of 0.374 . This value lies between 0.25 and 0.75 , which are slopes shown for reference to indicate, respectively, gold dissolution as $\mathrm{Au}_{2} \mathrm{O}$ (e.g., [Borisov and Palme, 1996] and Borisov and Palme, 2000 A. Borisov and H. Palme, Solubilities of noble metals in Fe-containing silicate melts as derived from experiments in $\mathrm{Fe}-$ free systems, Am. Mineral. 85 (2000), pp. 1665-1673. [Borisov and Palme, 2000]) and $\mathrm{Au}_{2} \mathrm{O}_{3}$, both $\mathrm{Au}^{1+}$ and $\mathrm{Au}^{3+}$ species being stable forms of gold commonly found in natural systems (e.g., Cotton, 1997). Therefore, gold dissolution in this $f \mathrm{O}_{2}$ range for our intermediate composition melts must involve the oxidized species $\mathrm{Au}^{3+}$. At first sight, a slope of 0.374 strongly suggests the contribution of $\mathrm{Au}^{3+}$ and $\mathrm{Au}^{0}$ (metal) in equivalent proportions. Another important point is that the data in the more reducing part of the diagram (Fig. 6a) do not lie on extensions of the slopes defined in the oxidized $f \mathrm{O}_{2}$ range. This is interpreted to suggest important changes in the dominant $\mathrm{Au}$ species with $f \mathrm{O}_{2}$. The observed slope of 0.045 along the reduced range may be the result of a gold solubility mechanism based mainly on the involvement of $\mathrm{Au}$ metal, with a minor contribution of $\mathrm{Au}^{1+}$. We conclude, therefore, that the Au solubility data cannot be satisfactorily fitted with a unique Au species in the entire $\mathrm{fO}_{2}$ range considered. Nevertheless, the data for the 3 intermediate compositions investigated consistently indicate a mechanism of Au solubility implying, at least in the oxidizing $f \mathrm{O}_{2}$ 
range, a more oxidized $\mathrm{Au}$ species (i.e., $\mathrm{Au}_{2} \mathrm{O}_{3}$ ) than found for the haplobasaltic system ([Borisov and Palme, 1996] and [Borisov and Palme, 2000]).

Concerning the $\mathrm{S}$-added charges, it is worth stressing that $f \mathrm{H}_{2} \mathrm{O}$, but also $f \mathrm{~S}_{2}$, vary along with $\mathrm{fO}_{2}$ so that the changes in Au solubility represented in Fig. $6 \mathrm{~b}$ can not be attributed to the influence of $f \mathrm{O}_{2}$ alone. Therefore, the effect of $f \mathrm{~S}_{2}$ on gold solubility has to be considered in detail in forthcoming studies.

\subsubsection{Constraints on gold speciation}

Data from this study have been analyzed in greater detail by assuming the existence of multiple dissolved Au species. It is worth stressing here that there is presently no direct spectroscopic evidence on the nature of Au species dissolved in silicate melts such as those presented here. Our analysis does not claim to substitute for such data and should be viewed as nothing more than a fit of our solubility measurements.

The measured gold solubility ( $\left.X_{\mathrm{Au}}\right)$ is the sum of all dissolved Au species present in the silicate melt, as:

\section{$\log X_{\text {mat }^{m}}^{\text {mat }}=x / 4 \log f \mathrm{O}_{2}+\mathrm{C}$}

where $n$ is the number of different dissolved Au species and $X$ dissolved gold species $i$. For each $X_{\mathrm{Aun}}^{\mathrm{m}} \mathrm{i} / 2$, we can write a dissolution equation such as Eq. (3). The main difference is that xi (the valence of the dissolved gold species $i$ ) is now an integer $\geqslant 0$. From Eq. (6), for each dissolved species we can write:

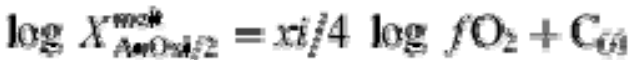

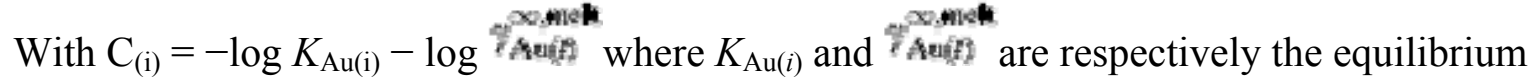
constant of the dissolution equation and the activity coefficient corresponding to the dissolved

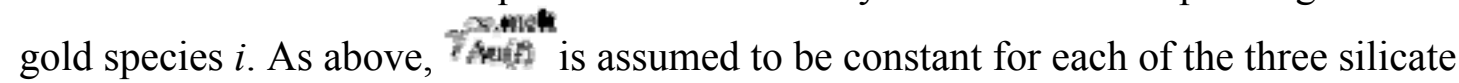
compositions investigated, which implies that $\mathrm{C}_{(i)}$ is a constant at fixed $P$ and $T$. By replacing the concentrations with their respective values, we obtain:

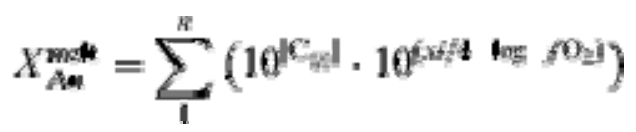

Eq. (9) has been used to fit our experimental gold solubility data. The constants $\mathrm{C}_{(i)}$ were determined by multiple linear regression from our solubility data at different $f \mathrm{O}_{2}$, i.e., their respective values were estimated by least-square minimization of the difference between measured and calculated $X_{\text {An }}^{\text {met }}$ (e.g., Albarède, 1995). Once the constants are determined, the concentration of each dissolved gold species can be calculated from Eq. (8).

Results with this approach are illustrated in Fig. 7, using experimental data obtained with the Bal2 composition. Several models involving combinations of two and three dissolved $\mathrm{Au}$ species were tested. The best model (the one minimizing the differences between measured 
and calculated Au concentrations) was obtained for a combination of three dissolved $\mathrm{Au}$ species $\left(\mathrm{Au}^{0}, \mathrm{Au}^{1+}\right.$ and $\left.\mathrm{Au}^{3+}, \mathrm{Fig} .7\right)$. Au concentrations in glasses calculated with this model are compared with experimental results on Fig. 7a. The agreement is shown to be excellent, providing an a posteriori validation of the model and, in particular, of the hypothesis of log heing constant with gold concentration for a given melt composition. Results with combinations of two species proved to be less satisfactory, significant differences being noted between computed and measured Au concentrations (Fig. 7b). The evolution of the relative proportions of the dissolved Au species with $f \mathrm{O}_{2}$ (Fig. 7c) shows a symmetrical variation for the metallic $\left(\mathrm{Au}^{0}\right)$ and the most oxidized species $\left(\mathrm{Au}^{3+}\right)$. Thus, $\mathrm{Au}^{0}$ decreases drastically when $f \mathrm{O}_{2}$ increases: it still represents $50 \%$ of gold dissolved in melt at $f \mathrm{O}_{2}$ around $\mathrm{NNO}+1.6$, but drops to $20 \%$ at NNO+2.6. For the most oxidizing conditions, about $70 \%$ of gold is present as $\mathrm{Au}^{3+}$. The proportion of the $\mathrm{Au}^{1+}$ species remains low $(<20 \%)$, showing little variation across the entire $f \mathrm{O}_{2}$ range (Fig. 7c). It is worth stressing that the species $\left(\mathrm{Au}^{1+}\right.$ and $\left.\mathrm{Au}^{3+}\right)$ used in the modelling of the Bal2 gold concentration data are considered as the two most stable and common forms of gold in nature (e.g., Cotton, 1997).

For the two other compositions, the measured gold concentrations were not satisfactorily reproduced by a combination of two or three species among $\mathrm{Au}^{0}, \mathrm{Au}^{1+}$ and $\mathrm{Au}^{3+}$. The best fits were "virtually" obtained with the involvement of other oxidized species, i.e., $\mathrm{Au}^{4+}$ for PhM5 and $\mathrm{Au}^{5+}$ for Pin Dac. However, neither $\mathrm{AuO}_{2}$ nor $\mathrm{Au}_{2} \mathrm{O}_{5}$ are reputedly stable gold oxides in natural systems, and especially in silicate melts at magmatic conditions (as opposed to hydrothermal conditions). Therefore, such species cannot be considered as acceptable alternatives. Neither can S-complexing with $\mathrm{Au}$ in the melt be considered as a possibility for the steepness of the line instead of more oxidized Au species, since starting materials sulfur contents are lower than $30 \mathrm{ppm}$ (Table 1). We have actually a small number of experiments to draw the line to evaluate the gold species in melt, so data interpretation must be made with caution. Nevertheless, although our modelling of Pin Dac and PhM5 gold speciation does not accurately reproduce the measured compositions by using a combination of $\mathrm{Au}^{0}, \mathrm{Au}^{1+}$ and $\mathrm{Au}^{3+}$, the gold dissolution mechanism appears qualitatively similar for the three hydrous intermediate composition melts investigated.

Our thermodynamic analysis requires that a neutral Au species is involved: for all compositions, at least $95 \%$ of gold is dissolved as $\mathrm{Au}^{0}$ at $\sim \mathrm{NNO}-1.5$ (see Bal2; Fig. 7c). This dissolution mechanism is not very effective for Au to be incorporated in melts as shown by the low gold contents of all reduced charges, irrespective of the starting composition (m $50 \mathrm{ppb} \mathrm{Au}$ ). Upon increasing $f \mathrm{O}_{2}$ above $\mathrm{NNO}$, oxidized $\mathrm{Au}$ species are involved whose stoichiometries are in detail dependent on the silicate melt base composition. For the three compositions, a minimum of gold solubility for a $\log f \mathrm{O}_{2}$ comprised between -10 and -10.75 $(-0.50<\Delta \mathrm{NNO}<+0.25)$ is found from the modelling (Fig. 7a). This minimum, which has been previously observed in a number of studies for precious metals (PGE, Borisov and Palme, 1996) as well as for some volatile elements, notably sulfur ([Scaillet and Pichavant, 2003], [Clemente et al., 2004] and [Scaillet and MacDonald, 2006]), also occurs in the same range as the change of iron speciation $\left(\mathrm{Fe}^{2+} / \mathrm{Fe}^{3+}\right)$ in silicate melts (Gaillard et al., 2001). It is here interpreted as reflecting the change in the gold dissolution mechanism from a $\mathrm{Au}^{0}$ dominated $f \mathrm{O}_{2}$ domain to an oxidized Au species-dominated $f \mathrm{O}_{2}$ domain.

\subsection{Influence of sulfur on the solubility of gold}

The gold dissolution data obtained with the Pin Dac composition in presence of sulfur under reducing conditions $\left(\mathrm{fO}_{2} \approx \mathrm{NNO}-1\right)$ show that the solubility of gold in silicate melts is 
dramatically enhanced (by 25-85 times) in comparison with S-free glasses at the same $f \mathrm{O}_{2}$ (Fig. 5). These results provide the first quantification of the dramatic influence of sulfur on the solubility of gold at $\mathrm{fO}_{2}<\mathrm{NNO}$. They confirm the highly chalcophile behavior of gold in hydrous melts previously noted in several studies ([Jugo et al., 1999], [Jugo et al., 2005] and [Simon et al., 2007]). Although the data presented in this study are too scarce to firmly constrain the dissolution mechanism of gold in presence of sulfur, oxidized gold species should be present in minor amounts at the $f \mathrm{O}_{2}$ of the S-added experiments. Dissolution of gold as neutral Au species is also unlikely since this would not account for the nearly two orders of magnitude increase of the solubility of gold when $\mathrm{S}$ is present (Fig. 5). Therefore, complexing between $\mathrm{Au}$ and $\mathrm{S}$ dissolved in the melt (as $\mathrm{S}^{2-}$ at $\mathrm{fO}_{2}<\mathrm{NNO}$; e.g., Clemente et al., 2004) most probably occurs, as shown by the correlation between the gold and sulfur concentrations in the melt (Fig. 8) and, for a given run, by the correlation between $\log X_{\mathrm{Au}}$ and $\log f \mathrm{~S}_{2}$ (Table 3 ), compatible with a $\mathrm{Au}-\mathrm{S}$ complex of stoichiometry $\mathrm{Au}_{2} \mathrm{~S}$.

\subsection{Influence of silicate melt composition on the solubility of gold}

The results presented above demonstrate that gold solubility in hydrous intermediate composition melts (1) is very sensitive to variations in $f \mathrm{O}_{2}$ but relatively insensitive to variation in $a \mathrm{H}_{2} \mathrm{O}$ (at constant $f \mathrm{O}_{2}$ ), (2) increases with $f \mathrm{O}_{2}$, implying a mechanism of dissolution involving at least one oxidized Au species and (3) is dramatically increased in the presence of sulfur. Below, we focus on the influence of the silicate composition on gold solubility.

Leaving the sulfur-added charges aside since they concern only one starting composition (Pin Dac), the maximum measured gold solubility values are identical for the three melt compositions studied ( $\sim 240 \mathrm{ppb}$ ), and occur at sub-equal $f \mathrm{O}_{2}(\sim \mathrm{NNO}+2.6$, Fig. 4). This observation runs counter to the starting hypothesis that adakitic magmas may incorporate more gold than typical calc-alkaline magmas. Yet, significant differences in $\mathrm{Au}$ concentrations are observed between the three melts. At $f \mathrm{O}_{2}$ less oxidizing than $\sim \mathrm{NNO}+2.6$, the intermediate adakite (Pin Dac) is less gold-enriched than the typical calc-alkaline magma (PhM5), the latter showing lower gold solubility values than the genuine adakite (Bal2). For conditions below NNO, the difference between the calc-alkaline and the adakite vanishes, but the intermediate adakite composition is still less enriched in gold (Fig. 4). It is worth emphasizing that these differences do not correlate with the respective degree of adakitic imprint of the melts in terms of trace elements contents and ratios (e.g., Sr/Y and $\mathrm{Y}$ ).

Therefore, the various degrees of adakitic imprint of the three starting compositions are not responsible for the observed differences in gold solubility. Such differences most likely arise because of the influence of other compositional factors, i.e., variations in major elements (typically in silica, alkalis and iron) between the three melts. These compositional factors do not come into play in the distinction between adakitic and non-adakitic magmatism (e.g., [Defant and Drummond, 1990], [Sen and Dunn, 1994], [Martin, 1999], [Defant et al., 2002] and [Martin et al., 2005]) and are, therefore, disconnected from any adakitic signature.

\subsection{Comparison with previous solubility data}

Most of previous studies focused on the determination of the partitioning of gold ([Bezmen et al., 1994], [Fleet et al., 1996], [Fleet et al., 1999], [Crocket et al., 1997], [Jugo et al., 1999], [Frank et al., 2002], [Simon et al., 2003], [Simon et al., 2005] and [Simon et al., 2007]) rather than carefully looking at its solubility in melt. Besides, the experimental conditions or melt compositions of the few studies reporting gold solubility data always differ from ours, making 
difficult any comparison. For instance, the solubility of gold in haplogranitic S-free melt at $800{ }^{\circ} \mathrm{C}$ and $1-1.5 \mathrm{kbar}-$ in presence of $\mathrm{NaCl}-\mathrm{KCl}-\mathrm{HCl}$-bearing fluids - is estimated at $\sim$ $500 \mathrm{ppb}$ ([Simon et al., 2003] and [Simon et al., 2005]) and 2.5 ppm (Simon et al., 2007) around NNO, and $\sim 1 \mathrm{ppm}$ at very reducing conditions ( $\sim N N O-3.5$; Frank et al., 2002). Despite a significant heterogeneity, all these values are much higher than our S-free data along the $f \mathrm{O}_{2}$ range investigated, but they do fit quite well with our results in presence of sulfur (see Fig. 5), probably because of the influence of high-salinity dissolved fluids. Borisov and Palme (1996) report gold solubility values from $\approx 300$ to $1000 \mathrm{ppb}$ in anhydrous haplobasaltic S-free melt at ambient pressure and $1300-1400{ }^{\circ} \mathrm{C}$, along the same $\mathrm{fO}_{2}$ range than ours. Those values still are significantly higher (by almost one order of magnitude) than our S-free data, most likely due to the very high experimental temperatures.

Concerning previous results in presence of sulfur, Simon et al. (2007) report a gold solubility of about $600 \mathrm{ppb}$ at mNNO (same experimental conditions and melt composition than their Sfree runs; see above) and Jugo et al. (2005) give evidence for a solubility on the order of $500 \mathrm{ppb}$ in anhydrous basaltic melt $\left(1300^{\circ} \mathrm{C}, 10 \mathrm{kbar}\right)$ in reducing conditions, while a solubility value of $\sim 800 \mathrm{ppb}$ is reported by Bezmen et al. (1994) in the Bushweld Complex melt ( $\left.\sim 56 \mathrm{wt} \% \mathrm{SiO}_{2}\right)$ saturated with $\mathrm{H}-\mathrm{C}-\mathrm{O}-\mathrm{S}$ fluids $\left(1300^{\circ} \mathrm{C}, 4 \mathrm{kbar}, \sim \mathrm{NNO}\right)$. Those three solubility values are noticeably lower than our own results at $\mathrm{NNO}-1$, albeit comparable to the lowest value of our S-added dataset (mul200 ppb). On the other hand, Jugo et al. (1999) report a gold solubility of about $4 \pm 2 \mathrm{ppm}$ in hydrous haplogranitic melt $\left(850^{\circ} \mathrm{C}, 1 \mathrm{kbar}\right)$ in reducing conditions that fits very well with our highest solubility value ( $\sim 4200 \mathrm{ppb})$.

\section{Implications for ore-forming processes}

\subsection{Importance of intensive parameters and magma source}

From the preceding discussion, it may be concluded that adakitic magmas are not more specialized with respect to gold incorporation and transport than other non-adakitic intermediate magmas. In fact, the variations in gold concentration that arise from compositional factors in this study are rather restricted, being much less than one order of magnitude (Fig. 5). In comparison, the range of gold concentrations in melts that results from experimental $f \mathrm{O}_{2}$ changes between $\sim \mathrm{NNO}-1$ to $\sim \mathrm{NNO}+3$ and, more markedly, from the addition of $\mathrm{S}$ to the system, is wider, exceeding one order of magnitude. Therefore - provided that gold is present in sufficient amount in the magma source(s) to potentially lead to the formation of economic deposits - what really matters to evaluate the ability of a given magma to incorporate and transport gold is the knowledge of the intensive magmatic parameters, mainly $f \mathrm{O}_{2}$ and $f \mathrm{~S}_{2}$.

Then, the testing of the starting hypothesis that adakitic magmas are specialized with respect to gold is equivalent to enquiring the $f \mathrm{O}_{2}$ and $f \mathrm{~S}_{2}$ of adakitic magmas. But, there is no indication in the literature about a systematic higher $f \mathrm{O}_{2}$ or sulfur-enrichment in adakites compared to typical calc-alkaline magmas. On the contrary, Wang et al. (2007), for instance, suggest a $f \mathrm{O}_{2}$ reduction by slab melts below South America. Then it might be suggested that some of the preferential associations observed between certain adakitic magmas and major gold deposits (e.g., [Baldwin and Pearce, 1982], [Thiéblemont et al., 1997], [Sajona and Maury, 1998], [Gonzalez-Partida et al., 2003], [Levresse et al., 2004] and [Rae et al., 2004]) may be related to a greater availability of gold in the magma source(s). 


\subsection{Slab melting as source of metals?}

Adakitic magmas mainly differ from normal subduction-linked calc-alkaline magmas by their typical trace element signatures (see Section 2.1) that led most authors to admit a predominant role of garnet fractionation during adakite petrogenesis. However, many hypotheses regarding the origin of adakites are still debated (see Richards and Kerrich (2007) for a recent synthesis). This includes notably the hydrous partial melting of subducted garnet-bearing metabasalts (original proposal of Kay, 1978 and Defant and Drummond, 1990, supported by many later authors including [Sajona et al., 1993], [Sajona et al., 1994], [Sajona et al., 2000a] and [Sajona et al., 2000b], and Stern and Kilian, 1996).

Concerning the gold (and sulfur) budget of adakitic magmas, the petrogenetic models involving slab partial melting may potentially lead to an enrichment of Au and $\mathrm{S}$ in melt compared to normal calc-alkaline magmas. According to this hypothesis, the subducted metabasalts would act both as protolith and source of metals. In the other models of adakite petrogenesis, as well as in the case of calc-alkaline magma genesis, sources of gold and other metals are mainly mantle protoliths from the wedge (Mungall, 2002), the latter containing on average up to $1.5 \mathrm{ppb} \mathrm{Au}$ (e.g., [Mitchell and Keays, 1981], [Lorand et al., 1999], [McInnes et al., 1999] and [Borisov and Palme, 2000]). In comparison, amphibolitic rocks (i.e., archean greentones and modern oceanic metabasalts) generally contain $<2 \mathrm{ppb} \mathrm{Au}$ ([Greenough and Fryer, 1990] and [Togashi and Terashima, 1997]). Borisova et al. (2006) estimated that a bulk slab composed of $90 \mathrm{wt} \%$ fresh MORB $+5 \mathrm{wt} \%$ altered MORB $+5 \mathrm{wt} \%$ sediment has $\mathrm{Au}$ concentrations up to $5 \mathrm{ppb} \mathrm{Au}$. Nevertheless, it is worth stressing that an average subducting oceanic crust is likely to be as well composed of at least several $\mathrm{wt} \%$ of polymetallic massive sulfides deposits. Herzig and Hannington (1995) report that gold concentrations are locally high in mid-ocean ridge deposits (up to $6.7 \mathrm{ppm} \mathrm{Au}$, with an overall average of $>1.2 \mathrm{ppm} \mathrm{Au}$ ), and may reach concentrations of more than $50 \mathrm{ppm}$ Au in massive sulfides from particular areas, like immature back-arc rifts. Thus, assuming an average amount of $5 \mathrm{wt} \%$ massive sulfides (with an average gold concentration of $1.2 \mathrm{ppm}$ ) in the subducting slab, 5-20\% partial melting of the bulk slab may lead to a sulfur-rich slab melt gold content ranging between 300 and $1200 \mathrm{ppb}$, provided that residual sulfide is minimal (i.e., most of sulfides dissolve into the partial melt; Mungall and Naldrett, 2008) and Au behaves as a highly incompatible element (Borisova et al., 2006). Therefore, and although the calculations need to be refined especially by taking into account the mobilities of $\mathrm{Au}$ and $\mathrm{S}$ in slab-dehydration fluids which are presently virtually unknown, the subducted slab clearly represents a potentially favourable protolith for the genesis of magmas specialized with respect to gold. This assumption is supported by the recent experimental work of Spandler et al. (2007) which shows that simple slab-dehydration models may be unable to account for trace element transfer from the slab to arc magmas.

\section{Conclusions}

The data presented here show that in a sulfur-free system the solubility of gold is similar in typical calc-alkaline and adakitic magmas with comparable silica content. For a given $f \mathrm{O}_{2}$ range, the gold concentrations appear very similar in the three compositions studied. The slight differences which can be noted between the three samples in the moderately oxidizing $\mathrm{fO}_{2}$ range are not correlated to an adakitic signature (the latter being linked essentially to the trace elements contents), but rather is controlled by compositional differences concerning the major elements, such as alkalinity and the iron content of the melt. The maximum gold solubility value reached in our S-free experiments ( $240 \mathrm{ppb} \mathrm{Au}$ at $\left.f \mathrm{O}_{2} \approx \mathrm{NNO}+2.6\right)$ is 
identical for the three magma compositions studied, suggesting that the compositional variations have a small influence of the solubility of gold for a given $f \mathrm{O}_{2}$ range. Oxygen fugacity controls the behaviour of gold in S-free silicate melts, making the Au case similar to that of other noble metals ([Borisov et al., 1994], [Borisov and Palme, 1995], [Borisov and Palme, 1996], [Borisov and Palme, 1997], [Borisov and Palme, 2000] and [Borisov and Nachtweyh, 1998]). The global increase of gold contents with $\mathrm{fO}_{2}$ implies a mechanism of dissolution based on oxidized species. Although multi-species dissolution models provide relatively satisfactory fits to the experimental data, they do not allow the nature of dissolved species to be specified and further work is needed to fill this gap.

The few experiments performed in the presence of sulfur under reducing conditions $\left(f \mathrm{O}_{2} \sim \mathrm{NNO}-1\right)$ show that this element dramatically enhances the solubility of gold in silicate melts, by up to nearly two orders of magnitude in this $\mathrm{fO}_{2}$ range. The remarkable increase of gold concentrations in glasses when $\mathrm{S}$ is added qualitatively suggests complexation between $\mathrm{Au}$ and $\mathrm{S}$ in the melt, as previously described for the platinum-group elements (e.g., Mungall and Naldrett, 2008, and references therein).

According to our experimental results, the preferential association observed between certain adakitic magmas and major gold deposits can not be related to any systematically more oxidized or S-rich characteristics. It is better explained - in some cases - by a significant slab melt component, particularly those melts that are derived from slabs containing metal-rich massive sulfides. These particular melts may be the ultimate source of Au-enriched magmas in arc settings.

\section{Acknowledgments}

This study forms part of the PhD thesis of the first author and has been supported by the French Ministry for Higher Education and Research, an Endeavour Research grant from the Australian government and the French GDR TRANSMET. S. Jego would like to acknowledge both Academia Sinica (Taipei, Taiwan) and the Institute of Earth Sciences for providing him with a postdoctoral fellowship during completion of this study. Discussions with G.F. Zellmer have improved the presentation of the data and the interpretation.

Constructive reviews were provided by P. Ulmer, B. Mysen and three anonymous reviewers.

\section{References}

Albarède, 1995 F. Albarède, Introduction to Geochemical Modelling, Cambridge University Press (1995).

Ancey et al., 1978 M. Ancey, F. Bastenaire and R. Tixier, Applications des méthodes statistiques en microanalyse, Microanalyse, Microscope Électronique à Balayage Edition de Physique, Orsay, France (1978) pp 323-347.

Aries et al., 2000 S. Aries, M. Valladon, M. Polve and B. Dupre, A routine method for oxide and hydroxide interference corrections in ICPMS chemical analysis of environmental and geological samples, Geostand. Newslett. 24 (2000), pp. 19-31. 
Baldwin and Pearce, 1982 J.A. Baldwin and J.A. Pearce, Discrimination of productive and non-productive porphyritic intrusions in the Chilean Andes, Econ. Geol. 77 (1982), pp. 664 674.

Behrens, $1995 \mathrm{H}$. Behrens, Determination of water solubilities in high viscosity melts: an experimental study on $\mathrm{NaAlSi}_{3} \mathrm{O}_{8}$ and $\mathrm{KAlSi}_{3} \mathrm{O}_{8}$ melts, Eur. J. Mineral. 7 (1995), pp. 905920.

Behrens et al., 1996 H. Behrens, C. Romano, M. Nowak, F. Holtz and D.B. Dingwell, Nearinfrared spectroscopic determination of water species in glasses of the system $\mathrm{MAlSi}_{3} \mathrm{O}_{8}$ $(\mathrm{M}=\mathrm{Li}, \mathrm{Na}, \mathrm{K})$ : an inter-laboratory study, Chem. Geol. 128 (1996), pp. 41-63.

Bellon and Yumul, 2000 H. Bellon and G.P. Yumul Jr., Mio-Pliocene magmatism in the Baguio Mining District (Luzon, Philippines): age clues to its geodynamic setting, C. R. Acad. Sci. Paris 331 (2000), pp. 295-302.

Bellon and Yumul, 2001 H. Bellon and G.P. Yumul Jr., Miocene to Quaternary adakites and related rocks in Western Philippine arc sequences, C. R. Acad. Sci. Paris 333 (2001), pp. 343350 .

Bernard et al., 1991 A. Bernard, D. Demaiffe, N. Mattielli and R.S. Punongbayan, Anhydritebearing pumices from Mount Pinatubo: further evidence for the existence of sulphur-rich silicic magmas, Nature 354 (1991), pp. 139-140.

Bernard et al., 1996 A. Bernard, U. Knittel, B. Weber, D. Weis, A. Albrecht, K. Hattori, J. Klein and D. Oles, Petrology and geochemistry of the 1991 eruption products of Mount Pinatubo (Luzon, Philippines). In: C. Newhall and R. Punongbayan, Editors, Fire and Mud: Eruptions and Lahars of Mount Pinatubo, Philippine Institute of Volcanology and Seismology/University of Washington Press, Quezon City/Seattle (1996), pp. 767-798.

Bezmen et al., 1994 N.I. Bezmen, M. Asif, G.E. Brügmann, I.M. Romanenko and A.J. Naldrett, Distribution of $\mathrm{Pd}, \mathrm{Rh}, \mathrm{Ru}, \mathrm{Ir}$, Os, and $\mathrm{Au}$ between sulfide and silicate melts, Geochim. Cosmochim. Acta 58 (1994), pp. 1251-1260.

Blevin and Chappell, 1992 D.L. Blevin and B.W. Chappell, The role of magma sources, oxidation states and fractionation in determining the granite metallogeny of eastern Australia, Trans. R. Soc. Edinb. Earth Sci. 83 (1992), pp. 305-316.

Borisov and Nachtweyh, 1998 Borisov A. and Nachtweyh K. (1998) Ru solubility in silicate melts: experimental results in oxidizing region. Lunar Planet. Sci. Conf. XXIX. Lunar Planet. Inst., Houston. \#1320 (abstr.).

Borisov and Palme, 1995 A. Borisov and H. Palme, Solubility of iridium in silicate melts: new data from experiments with $\operatorname{Ir}_{10} \mathrm{Pt}_{90}$ alloys, Geochim. Cosmochim. Acta 59 (1995), pp. $481-485$.

Borisov and Palme, 1996 A. Borisov and H. Palme, Experimental determination of the solubility of Au in silicate melts, Mineral. Petrol. 56 (1996), pp. 297-312. 
Borisov and Palme, 1997 A. Borisov and H. Palme, Experimental determination of the solubility of platinum in silicate melts, Geochim. Cosmochim. Acta 61 (1997), pp. 4349-4357.

Borisov and Palme, 2000 A. Borisov and H. Palme, Solubilities of noble metals in Fecontaining silicate melts as derived from experiments in Fe-free systems, Am. Mineral. 85 (2000), pp. 1665-1673.

Borisov et al., 1994 A. Borisov, H. Palme and B. Spettel, Solubility of Pd in silicate melts: implications for core formation in the Earth, Geochim. Cosmochim. Acta 58 (1994), pp. 705 716.

Borisova et al., 2006 A.Y. Borisova, M. Pichavant, M. Polvé, M. Wiedenbeck, R. Freydier and F. Candaudap, Trace element geochemistry of the 1991 Mt. Pinatubo silicic melts, Philippines: implications for ore-forming potential of adakitic magmatism, Geochim. Cosmochim. Acta 70 (2006), pp. 3702-3716.

Burnham, 1979 C.W. Burnham, The importance of volatile constituents, The Evolution of the Igneous Rocks: Fiftieth Anniversary Perspectives, Princeton University Press (1979) p. 439 (Chapter 16).

Chou, 1986 I.-M. Chou, Permeability of precious metals to hydrogen at $2 \mathrm{~kb}$ total pressure and elevated temperatures, Am. J. Sci. 286 (1986), pp. 638-658.

Clemente et al., 2004 B. Clemente, B. Scaillet and M. Pichavant, The solubility of sulphur in hydrous rhyolitic melts, J. Petrol. 45 (2004), pp. 2171-2196.

Cotten et al., 1995 J. Cotten, A. Le Dez, M. Bau, M. Caroff, R.C. Maury, P. Dulski, S. Fourcade, M. Bohn and R. Brousse, Origin of anomalous rare-earth element and yttrium enrichments in subaerially exposed basalts: evidence from French Polynesia, Chem. Geol. 119 (1995), pp. 115-138.

Cotton, 1997 Cotton S.A. (1997) Chemistry of precious metals. Chapter 4. Silver and Gold. Blackie Academic and Professional, Chapman \& Hall, London, UK. p. 365.

Crocket et al., 1997 J.H. Crocket, M.E. Fleet and W.E. Stone, Implications of composition for experimental partitioning of platinum-group elements and gold between sulfide liquid and basalt melt: the significance of nickel content, Geochim. Cosmochim. Acta 61 (1997), pp. 4139-4149.

Dall'Agnol et al., 1999 R. Dall'Agnol, B. Scaillet and M. Pichavant, An experimental study of a lower proterozoic A-type granite from the Eastern Amazonian Craton, Braz. J. Petrol. 40 (1999), pp. 1673-1698.

Defant and Drummond, 1990 M.J. Defant and M.S. Drummond, Derivation of some modern arc magmas by melting of young subducted lithosphere, Nature 347 (1990), pp. 662-665.

Defant et al., 2002 M.J. Defant, J.F. Xu, P. Kepezhinskas, Q. Wang, Q. Zhang and L. Xiao, Adakites: some variations on a theme, Acta Petrol. Sin. 18 (2002), pp. 129-142. 
Di Carlo et al., 2006 I. Di Carlo, M. Pichavant, S.G. Rotolo and B. Scaillet, Experimental crystallization of a high-K arc basalt: the Golden Pumice, Stromboli volcano (Italy), J. Petrol. 47 (2006), pp. 1317-1343.

Fleet et al., 1996 M.E. Fleet, J.H. Crocket and W.E. Stone, Partitioning of platinum-group elements (Os, Ir, Ru, Pt, Pd) and gold between sulfide liquid and basalt melt, Geochim. Cosmochim. Acta 60 (1996), pp. 2397-2412.

Fleet et al., 1999 M.E. Fleet, J.H. Crocket, M. Liu and W.E. Stone, Laboratory partitioning of platinum-group elements (PGE) and gold with application to magmatic sulfide-PGE deposits, Lithos 47 (1999), pp. 127-142.

Frank et al., 2002 M.R. Frank, P.A. Candela, P.M. Piccoli and M.D. Galscock, Gold solubility, speciation and partitioning as a function of $\mathrm{HCl}$ in the brine-silicate melt-metallic gold system at $800^{\circ} \mathrm{C}$ and $100 \mathrm{MPa}$, Geochim. Cosmochim. Acta 66 (2002), pp. 3719-3732.

Froese and Gunter, 1976 E. Froese and A.E. Gunter, A note on the pyrrhotite-sulfur vapour equilibrium, Econ. Geol. 71 (1976), pp. 1589-1594.

Gaillard et al., 2001 F. Gaillard, B. Scaillet, M. Pichavant and J.-M. Beny, The effect of water and $\mathrm{fO}_{2}$ on the ferric-ferrous ratio of silicic melts, Chem. Geol. 174 (2001), pp. 255-273.

Gerlach et al., 1996 T.M. Gerlach, H.F. Westrich and R.B. Symonds, Pre-eruption vapor in magma of the climactic Mount Pinatubo eruption: source of the giant stratospheric sulfur dioxide cloud. In: Ch.G. Newhall and R.S. Punongbayan, Editors, Fire and Mud. Eruptions and Lahars of Mt. Pinatubo, Philippines, Philippine Institute of Volcanology and Seismology/University of Washington Press, Quezon City/Seattle (1996), pp. 415-431.

Gonzalez-Partida et al., 2003 E. Gonzalez-Partida, G. Levresse, A. Carrillo-Chavez, A. Cheilletz, D. Gasquet and J. Solorio-Munguia, (Au-Fe) Skarn deposits of the Mezcala district, South-Central Mexico: adakite association of the mineralizing fluids, Int. Geol. Rev. 45 (2003), pp. 79-94.

Greenough and Fryer, 1990 J.D. Greenough and B.J. Fryer, Proc. Ocean Drill, Program Sci. Results 115 (1990), p. 71.

Gunter et al., 1987 M.D. Gunter, J. Myers and S. Girsperberg, Hydrogen: metal membranes. In: H.L. Barnes and G.C. Ulmer, Editors, Hydrothermal Experimental Techniques, Wiley, New York (1987), pp. 100-120.

Halter et al., 2002 W.E. Halter, T. Pettke and C.A. Heinrich, The origin of $\mathrm{Cu} / \mathrm{Au}$ ratios in porphyry-type ore deposits, Science 296 (2002), pp. 1844-1846.

Harris et al., 2003 A.C. Harris, V.S. Kamenetsky, N.C. White, E. van Achterbergh and C.G. Ryan, Melt inclusions in veins: linking magmas and porphyry $\mathrm{Cu}$ deposits, Science 302 (2003), pp. 2109-2111.

Hattori and Keith, 2001 K.H. Hattori and J.D. Keith, Contribution of mafic melt to porphyry copper mineralization: evidence from Mount Pinatubo, Philippines, and Bingham Canyon, Utah, USA, Mineral. Depos. 36 (2001), pp. 799-806. 
Hedenquist and Lowenstern, 1994 J.W. Hedenquist and J.B. Lowenstern, The role of magmas in the formation of hydrothermal ore deposits, Nature 370 (1994), pp. 519-527.

Herzig and Hannington, 1995 P.M. Herzig and M.D. Hannington, Polymetallic massive sulfides at the modern seafloor: a review, Ore Geol. Rev. 10 (1995), pp. 95-115.

Holtz et al., 1992 F. Holtz, H. Behrens, D.B. Dingwell and R.P. Taylor, Water solubility in alumino-silicate melts of haplogranite composition at 2 kbar, Chem. Geol. 96 (1992), pp. 289-302.

Holtz et al., 1995 F. Holtz, H. Behrens, D.B. Dingwell and W. Johannes, $\mathrm{H}_{2} \mathrm{O}$ solubility in haplogranitic melts: compositional, pressure, and temperature dependence, Am. Mineral. 80 (1995), pp. 94-108.

Imai, $2001 \mathrm{~A}$. Imai, Generation and evolution of ore fluids for porphyry $\mathrm{Cu}-\mathrm{Au}$ mineralization of the Santo Tomas II (Philex) deposit, Philippines, Res. Geol. 51 (2001), pp. 71-96.

Imai, 2002 A. Imai, Metallogenesis of porphyry $\mathrm{Cu}$ deposits of the western Luzon arc, Philippines: $\mathrm{K}-\mathrm{Ar}$ ages, $\mathrm{SO}_{3}$ contents of microphenocrystic apatite and significance of intrusive rocks, Res. Geol. 52 (2002), pp. 147-161.

Imai et al., 1996 A. Imai, E.L. Listanco and T. Fujii, Highly oxidized and sulfur-rich magma of Mount Pinatubo: implication for metallogenesis of porphyry copper mineralization in the western Luzon arc. In: C.G. Newhall and R.S. Punongbayan, Editors, Fire and Mud: Eruptions and Lahars of Mount Pinatubo, Philippines, Philippine Institute of Volcanology and Seismology/University of Washington Press, Quezon City/Seattle (1996), pp. 65-874.

Ishihara, 1981 Ishihara S. (1981) Deposits and regional metamorphism. Econ. Geol. 75th Anniv. vol. 458-484.

Jego et al., 2005 S. Jego, R.C. Maury, M. Polvé, G.P. Yumul Jr., H. Bellon, R.A. Tamayo Jr. and J. Cotten, Geochemistry of adakites from the Philippines: constraints on their origins, Res. Geol. 55 (2005), pp. 163-187.

Jugo et al., 1999 P.J. Jugo, P.A. Candela and P.M. Piccoli, Magmatic sulfides and Au:Cu ratios in porphyry deposits: an experimental study of copper and gold partitioning at $850{ }^{\circ} \mathrm{C}$, $100 \mathrm{MPa}$ in a haplogranitic melt-pyrrhotite-intermediate solid solution-gold metal assemblage, at gas saturation, Lithos 46 (1999), pp. 573-589.

Jugo et al., 2005 P.J. Jugo, R.W. Luth, J.P. Richards, P.J. Sylvester and M.N. Tubrett, Experimental determination of the solubilities of $\mathrm{Ir}, \mathrm{Pt}, \mathrm{Pd}$ and $\mathrm{Au}$ in sulfide- and sulfatesaturated basaltic melts at $1300{ }^{\circ} \mathrm{C}$ and $1 \mathrm{GPa}$ : implications for HSE fractionation in subduction zones, Geophys. Res. Abstr. 7 (2005), p. 04879.

Kay, 1978 S.M. Kay, Aleutian magnesian andesites: melts from subducted Pacific ocean crust, J. Volc. Geotherm. Res. 4 (1978), pp. 117-132. 
Keays and Skinner, 1989 R.R. Keays and B.J. Skinner, Introduction to: the geology of gold deposits: the perspective in 1988. In: R.R. Keays, W.R.H. Ramsay and D.I. Groves, Editors, Economic Geology Monograph 6, The Economic Geology Publishing Company (1989).

Kress, 1997 V. Kress, Magma mixing as a source for Pinatubo sulphur, Nature 389 (1997), pp. 591-593.

Levresse et al., 2004 G. Levresse, E. Gonzalez-Partida, A. Carrillo-Chavez, J. Tritlla, A. Camprubi, A. Cheilletz, D. Gasquet and E. Deloule, Petrology, U/Pb dating and $(\mathrm{C}-\mathrm{O})$ stable isotope constraints on the source and evolution of the adakite-related Mezcala Fe-Au skarn district, Guerrero, Mexico, Mineral. Depos. 39 (2004), pp. 301-312

Linnen et al., 1995 R.L. Linnen, M. Pichavant, F. Holtz and S. Burgess, The effect of $f \mathrm{O}_{2}$ on the solubility, diffusion, and speciation of tin in haplogranitic melt at $850{ }^{\circ} \mathrm{C}$ and $2 \mathrm{kbar}$, Geochim. Cosmochim. Acta 59 (1995), pp. 1579-1588.

Liu et al., 2004 Y. Liu, Y. Zhang and H. Behrens, $\mathrm{H}_{2} \mathrm{O}$ diffusion in dacitic melts, Chem. Geol. 209 (2004), pp. 327-340.

Lorand et al., 1999 J.-P. Lorand, L. Pattou and M. Gros, Fractionation of platinum-group elements and gold in the upper mantle: a detailed study in Pyrenean orogenic lherzolites, $J$. Petrol. 40 (1999), pp. 957-981.

Martel et al., 1999 C. Martel, M. Pichavant, F. Holtz, B. Scaillet, J.-L. Bourdier and H. Traineau, Effects of $f \mathrm{O}_{2}$ and $\mathrm{H}_{2} \mathrm{O}$ on andesite phase relations between 2 and $4 \mathrm{kbar}, J$. Geophys. Res. 104 (1999), pp. 29453-29470.

Martin, 1999 H. Martin, Adakitic magmas: modern analogues of Archean granitoids, Lithos 46 (1999), pp. 411-429.

Martin et al., 2005 H. Martin, R.H. Smithies, R. Rapp, J.-F. Moyen and D. Champion, An overview of adakite, tonalite-trondhjemite-granodiorite (TTG), and sanukitoid: relationship and some implications for crustal evolution, Lithos 79 (2005), pp. 1-24.

Mathur et al., 2000 R. Mathur, J. Ruiz, S. Titley, S. Gibbins and W. Margotomo, Different crustal sources for Au-rich and Au-poor ores of the Grasberg $\mathrm{Cu}-\mathrm{Au}$ porphyry deposit, Earth Planet. Sci. Lett. 183 (2000), pp. 7-14.

McInnes et al., 1999 B.I.A. McInnes, J.S. McBride, N.J. Evans, D.D. Lambert and A.S. Andrew, Osmium isotope constraints on ore metal recycling in subduction zones, Science 286 (1999), pp. 512-516.

Mitchell and Keays, 1981 R.H. Mitchell and R.R. Keays, Abundance and distribution of gold, palladium and iridium in some spinel and garnet lherzolites: implications for the nature and origin of precious metal-rich intergranular components in the upper mantle, Geochim. Cosmochim. Acta 45 (2425-2433) (1981), pp. 2435-2442.

Müller and Groves, 1993 D. Müller and D.I. Groves, Direct and indirect associations between potassic igneous rocks, shoshonites and gold-copper deposits, Ore Geol. Rev. 8 (1993), pp. 383-406. 
Mungall, 2002 J.E. Mungall, Roasting the mantle: slab melting and the genesis of major Au and Au-rich Cu deposits, Geology 30 (2002), pp. 915-918.

Mungall and Naldrett, 2008 J.E. Mungall and A.J. Naldrett, Ore deposits of the Platinumgroup elements, Elements 4 (2008), pp. 253-258.

Ohmoto and Kerrick, 1977 H. Ohmoto and D.M. Kerrick, Devolatilisation equilibria in graphitic systems, Am. J. Sci. 277 (1977), pp. 1013-1044

O’Neill et al., 1995 H. O’Neill, C. St, D.B. Dingwell, A. Borisov, B. Spettel and H. Palme, Experimental petrochemistry of some highly siderophile elements at high temperatures, and some implications for core formation and the mantle's early history, Chem. Geol. 120 (1995), pp. 255-273.

Pichavant et al., 2002 M. Pichavant, C. Martel, J.-L. Bourdier and B. Scaillet, Physical conditions, structure, and dynamics of a zoned magma chamber: Mount Pelee (Martinique, Lesser Antilles Arc), J. Geophys. Res. 107 (2002), pp. 2093-2122.

Polve et al., 2007 M. Polve, R.C. Maury, S. Jego, H. Bellon, A. Margoum, G.P. Yumul Jr., B. Payot, R.A. Tamayo Jr. and J. Cotten, Temporal geochemical evolution of Neogene magmatism in the Baguio gold-copper mining district (Northern Luzon, Philippines), Resour. Geol. 57 (2007), pp. 197-218.

Pownceby and O'Neill, 1994 M.I. Pownceby and H. O'Neill, Thermodynamic data from redox reactions at high temperature. III. Activity-composition relations in $\mathrm{Ni}-\mathrm{Pd}$ alloys from EMF measurements at $850-1250 \mathrm{~K}$, and calibration of the $\mathrm{NiO}+\mathrm{Ni}-\mathrm{Pd}$ assemblage as a redox sensor, Contrib. Mineral. Petrol. 116 (1994), pp. 327-339.

Prouteau and Scaillet, 2003 G. Prouteau and B. Scaillet, Experimental constraints on the origin of the 1991 Pinatubo dacite, J. Petrol. 44 (2003), pp. 2203-2241

Prouteau et al., 2000 G. Prouteau, R.C. Maury, F.G. Sajona, J. Cotton and J.-L. Joron, Behaviour of Niobium, Tantalum and other high field strength elements in adakites and related lavas from the Philippines, Island Arc 9 (2000), pp. 487-498.

Rae et al., 2004 A.J. Rae, D.R. Cooke, D. Phillips and M. Zaide-Delfin, The nature of magmatism at Palinpinon geothermal field, Negros Island, Philippines: implications for geothermal activity and regional tectonics, J. Volc. Geotherm. Res. 129 (2004), pp. 321-342.

Richards, 1990 J.P. Richards, Petrology and geochemistry of alkaline intrusives at the Porgera gold deposit, Papua New Guinea, J. Geochem. Explor. 35 (1990), pp. 141-199.

Richards and Kerrich, 2007 J.P. Richards and R. Kerrich, Adakite-like rocks: their diverse origins and questionable role in metallogenesis, Econ. Geol. 102 (2007), pp. 537-576.

Robie et al., 1978 R.A. Robie, B.S. Hemingway and J.R. Fisher, Thermodynamic properties of minerals and related substances at $198.15 \mathrm{~K}$ and 1 bar $\left(10^{5}\right.$ Pascals $)$ pressure and at higher temperature, Geol. Surv. Bull. 1452 (1978), p. 456. 
Roux and Lefèvre, 1992 J. Roux and A. Lefèvre, A fast-quench device for internally heated pressure vessels, Eur. J. Mineral. 19894 (1992), pp. 279-281.

Sajona and Maury, 1998 F.G. Sajona and R.C. Maury, Association of adakites with gold and copper mineralization in the Philippines, C. R. Acad. Sci. Paris, Earth Planet. Sci. 326 (1998), pp. 27-34.

Sajona et al., 1993 F.G. Sajona, R.C. Maury, H. Bellon, M.J. Defant, J. Cotten, M. Pubellier and C. Rangin, Initiation of subduction and the generation of slab melts in western and eastern Mindanao, Philippines, Geology 21 (1993), pp. 1007-1010.

Sajona et al., 1994 F.G. Sajona, H. Bellon, R.C. Maury, M. Pubellier, J. Cotten and C. Rangin, Magmatic response to abrupt changes in tectonic setting: pliocene-Quaternary calc-alkaline lavas and $\mathrm{Nb}$-enriched basalts of Leyte and Mindanao (Philippines), Tectonophysics 237 (1994), pp. 47-72.

Sajona et al., 2000a F.G. Sajona, R.C. Maury, G. Prouteau, J. Cotten, P. Schiano, H. Bellon and L. Fontaine, Slab melt as metasomatic agent in island arc magma mantle sources, Negros and Batan (Philippines), Island Arc 9 (2000), pp. 472-486

Sajona et al., 2000b F.G. Sajona, R.C. Maury, M. Pubellier, J. Leterrier, H. Bellon and J. Cotten, Magmatic source enrichment by slab-derived melts in a young post-collision setting, central Mindanao (Philippines), Lithos 54 (2000), pp. 173-206.

Scaillet and Evans, 1999 B. Scaillet and B.W. Evans, The 15 June 1991 eruption of Mount Pinatubo. I. Phase equilibria and pre-eruption $\mathrm{P}-\mathrm{T}-\mathrm{fO}_{2}-f \mathrm{H}_{2} \mathrm{O}$ conditions of the dacite magma, J. Petrol. 40 (1999), pp. 381-411.

Scaillet and MacDonald, 2006 B. Scaillet and R. MacDonald, Experimental and thermodynamic constraints on the sulphur yield of peralkaline and metaluminous silicic flood eruptions, J. Petrol. 47 (2006), pp. 1413-1437

Scaillet and Pichavant, 2003 B. Scaillet and M. Pichavant, Experimental constraints on volatile abundances in arc magmas and their implications for degassing processes. In: $\mathrm{C}$. Oppenheimer, D.M. Pyle and J. Barclay, Editors, Volcanic Degassing vol. 213, Geological Society, London (2003), pp. 23-52 Special Publications.

Scaillet et al., 1992 B. Scaillet, M. Pichavant, J. Roux, G. Humbert and A. Lefevre, Improvements of the Shaw membrane technique for measurement and control of $f \mathrm{H}_{2}$ at high temperatures and pressures, Am. Mineral. 77 (1992), pp. 647-655.

Scaillet et al., 1995 B. Scaillet, M. Pichavant and J. Roux, Experimental crystallisation of leucogranite magmas, J. Petrol. 36 (1995), pp. 663-705.

Schmidt et al., 1997 B.C. Schmidt, F. Holtz, B. Scaillet and M. Pichavant, The influence of $\mathrm{H}_{2} \mathrm{O}-\mathrm{H}_{2}$ fluids and redox conditions on melting temperatures in the haplogranite system, Contrib. Mineral. Petrol. 126 (1997), pp. 386-400. 
Sen and Dunn, 1994 C. Sen and T. Dunn, Dehydration melting of a basaltic composition amphibolite at 1.5 and $2.0 \mathrm{GPa}$ : implications for the origin of adakites, Contrib. Mineral. Petrol. 117 (1994), pp. 394-409.

Sillitoe, 1989 Sillitoe R.H. (1989) Gold deposits in western Pacific island arcs: the magmatic connection. In The Geology of Gold Deposits: The Perspective in 1988. Economic Geology Monograph 6, (eds. R.R. Keays, W.R.H. Ramsay and D.I. Groves). Economic Geology Publishing Co, pp. 274-291.

Sillitoe, 1997 R.H. Sillitoe, Characteristics and controls of the largest porphyry copper-gold and epithermal gold deposits in the circum-Pacific region, Aust. J. Earth Sci. 44 (1997), pp. $373-388$.

Sillitoe and Bonham, 1990 R.H. Sillitoe and H.F. Bonham Jr., Sediment-hosted gold deposits: distal products of magmatic-hydrothermal systems, Geology 18 (1990), pp. 157-161.

Simon et al., 2003 A.C. Simon, T. Pettke, P.A. Candela, P.M. Piccoli and C.A. Heinrich, Experimental determination of Au solubility in rhyolite melt and magnetite: constraints on magmatic Au budgets, Am. Miner. 88 (2003), pp. 1644-1651.

Simon et al., 2005 A.C. Simon, M.R. Frank, T. Pettke, P.A. Candela, P.M. Piccoli and C.A. Heinrich, Gold partitioning in melt-vapor-brine systems, Geochim. Cosmochim. Acta 69 (2005), pp. 3321-3335.

Simon et al., 2007 A.C. Simon, T. Pettke, P.A. Candela, P.M. Piccoli and C.A. Heinrich, The partitioning behaviour of As and $\mathrm{Au}$ in S-free and S-bearing magmatic assemblages, Geochim. Cosmochim. Acta 71 (2007), pp. 1764-1782.

Spandler et al., 2007 C. Spandler, J. Mavrogenes and J. Hermann, Experimental constraints on element mobility from subducted sediments using high-P synthetic fluid/melt inclusions, Chem. Geol. 239 (2007), pp. 228-249.

Stern and Kilian, 1996 C.R. Stern and R. Kilian, Role of the subducted slab, mantle wedge and continental crust in the generation of adakites from the Andean Austral Volcanic Zone, Contrib. Mineral. Petrol. 123 (1996), pp. 263-281.

Sun and McDonough, 1989 S.-S. Sun and W.F. McDonough, Chemical and isotopic systematics of oceanic basalts: implications for mantle composition and processes. In: A.D. Saunders and M.J. Norry, Editors, Magmatism in the Ocean Basins vol. 42, Geol. Soc. Special Publ. (1989), pp. 313-345.

Sun et al., 2003 W. Sun, V.C. Bennett, S.M. Eggins, R.J. Arculus and M.R. Perfit, Rhenium systematics in submarine MORB and Back-arc basin glasses: laser ablation ICP-MS results, Chem. Geol. 196 (2003), pp. 259-281.

Sun et al., 2004 W. Sun, R.J. Arculus, V.S. Kamenetsky and R.A. Binns, Release of goldbearing fluids in convergent margin magmas prompted by magnetite crystallization, Nature 431 (2004), pp. 975-978. 
Taylor et al., 1992 J.R. Taylor, V.J. Wall and M.I. Pownceby, The calibration and application of accurate redox sensors, Am. Mineral. 77 (1992), pp. 284-295.

Thiéblemont et al., 1997 D. Thiéblemont, G. Stein and J.-L. Lescuyer, Epithermal and porphyry deposits: the adakite connection, C. R. Acad. Sci. Paris, Earth Planet. Sci. 325 (1997), pp. 103-109.

Togashi and Terashima, $1997 \mathrm{~S}$. Togashi and S. Terashima, The behaviour of gold in unaltered island arc tholeiitic rocks from Izu-Oshima, Fuji, and Osoreyama volcanic areas, Japan, Geochim. Cosmochim. Acta 61 (1997), pp. 543-554.

Truckenbrodt and Johannes, 1999 J. Truckenbrodt and W. Johannes, $\mathrm{H}_{2} \mathrm{O}$ loss during pistoncylinder experiments, Am. Mineral. 84 (1999), pp. 1333-1335.

Ulrich et al., 1999 T. Ulrich, D. Günther and C.A. Heinrich, Gold concentrations of magmatic brines and the metal budget of porphyry copper deposits, Nature 399 (1999), pp. 676-679.

Wallace and Gerlach, 1994 P.J. Wallace and T.M. Gerlach, Magmatic vapour source for sulfur dioxide released during volcanic eruptions: evidence from Mount Pinatubo, Science 265 (1994), pp. 497-499.

Wang et al., 2007 J. Wang, K.H. Hattori, R. Kilian and C.R. Stern, Metasomatism of sub-arc mantle peridotites below southern South America: reduction of $f \mathrm{O}_{2}$ by slab-melt, Contrib. Mineral. Petrol. 153 (2007), pp. 607-624.

Watson, 1994 E.B. Watson, Diffusion in volatile-bearing magmas, Rev. Miner. 30 (1994), pp. $371-411$.

Westrich, 1987 H.R. Westrich, Determination of water in volcanic glasses by Karl-Fischer titration, Chem. Geol. 63 (1987), pp. 335-340

Westrich and Gerlach, 1992 H.R. Westrich and T.M. Gerlach, Magmatic gas source for the stratospheric $\mathrm{SO}_{2}$ cloud from the June 15, 1991, eruption of Mount Pinatubo, Geology 20 (1992), pp. 867-870.

White and Hedenquist, 1990 N.C. White and J.W. Hedenquist, Epithermal environments and styles of mineralization: variations and their causes, and guidelines for exploration, $J$.

Geochem. Explor. 36 (1990), pp. 445-474.

White and Hedenquist, 1995 N.C. White and J.W. Hedenquist, Epithermal gold deposits: styles, characteristics and exploration, Soc. Econ. Geol. 23 (1995), pp. 8-13.

Yumul et al., 2000 G.P. Yumul Jr., C.B. Dimalanta, H. Bellon, D.V. Faustino, J.V. De Jesus, R.A. Tamayo Jr. and F.T. Jumawan, Adakitic lavas in the Central Luzon back-arc region, Philippines: lower crust partial melting products ?, Island Arc 9 (2000), pp. 499-512.

\section{Figures and Tables}



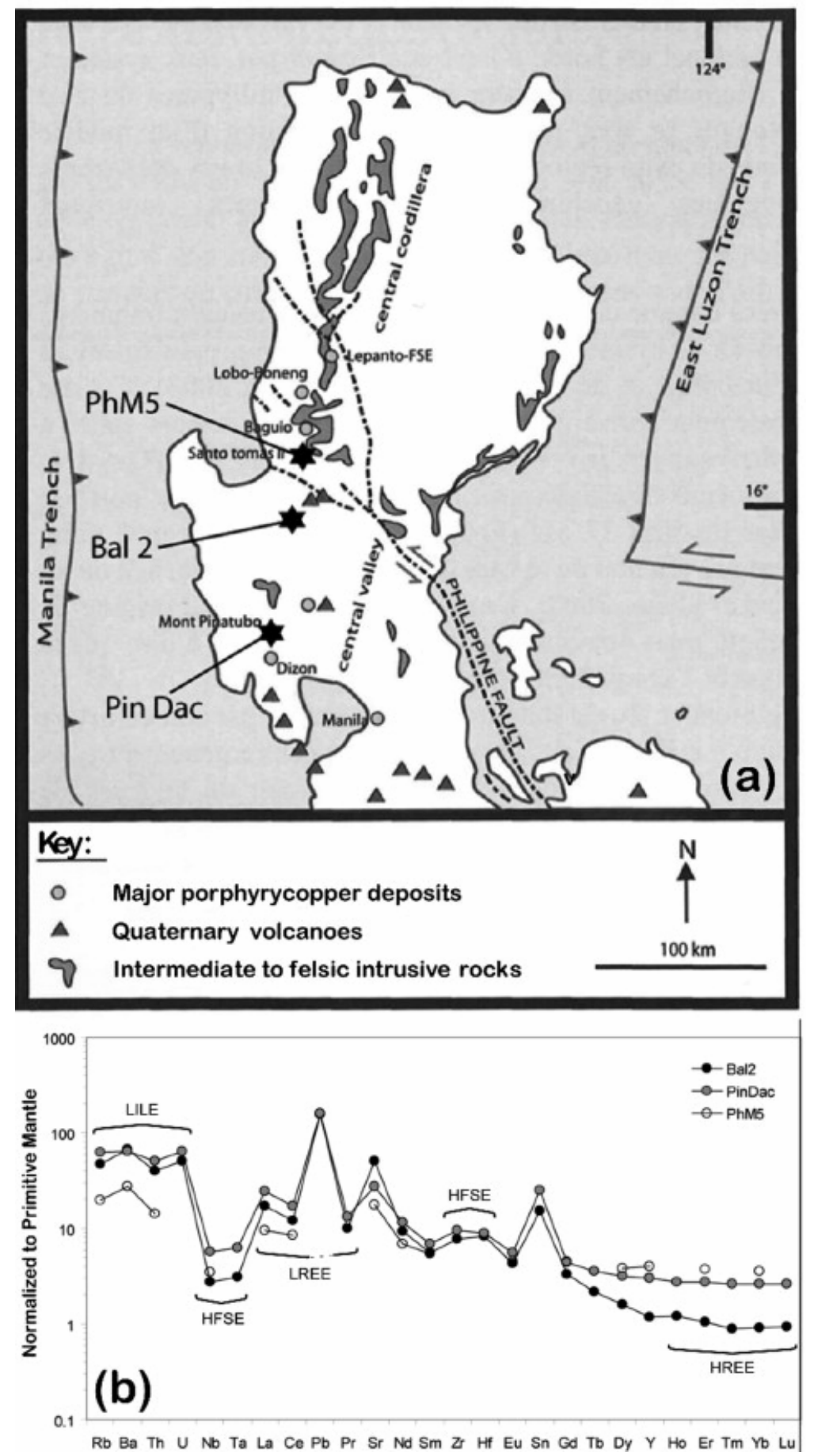

Fig. 1. : (a) Schematic map of North Luzon (Philippines) showing the sampling locations of the three starting rocks. (b) Extended trace elements spidergram for the three starting rocks; contents are normalized to the primitive mantle (values from Sun and McDonough, 1989). LILE, large ion lithophile elements; HFSE, high field strength elements; LREE, light rare earth elements; HREE, heavy rare earth elements.

Table 1. Main geochemical and petrologic charecteristics of the starting rocks.

\begin{tabular}{|l|l|l|l|}
\hline Sample & Bal2 & Pin Dac & phM5 \\
\hline Region & EVC & WVC & Baeulo \\
\hline
\end{tabular}




\begin{tabular}{|c|c|c|c|}
\hline Sample & Bal2 & Pin Dac & phM5 \\
\hline Location & Balungao Dome & Pinatubo Volcano & Philex Mine \\
\hline Type & Diorite & Dacite & Diorite \\
\hline Age (Ma) & 0.32 & 0.00 & 3.03 \\
\hline \multicolumn{4}{|c|}{ Major elements (wt\%) } \\
\hline $\mathrm{SiO}_{3}$ & 62.00 & 64.50 & 61.50 \\
\hline $\mathrm{TiO}_{2}$ & 0.35 & 0.49 & 0.51 \\
\hline $\mathrm{Al}_{2} \mathrm{O}_{3}$ & 15.50 & 16.00 & 16.50 \\
\hline $\mathrm{Fe}_{2} \mathrm{O}_{3}$ & 4.40 & 4.21 & 5.60 \\
\hline $\mathrm{MnO}$ & 0.07 & 4.10 & 0.09 \\
\hline $\mathrm{MgO}$ & 5.46 & 2.45 & 2.06 \\
\hline $\mathrm{CaO}$ & 5.40 & 5.18 & 6.32 \\
\hline $\mathrm{Na}_{2} \mathrm{O}$ & 4.66 & 4.68 & 4.55 \\
\hline $\mathrm{K}_{2} \mathrm{O}$ & 1.54 & 1.53 & 0.60 \\
\hline $\mathrm{P}_{2} \mathrm{O}_{5}$ & 0.10 & 0.17 & 0.12 \\
\hline L.O.I. & 0.59 & - & 1.75 \\
\hline Total & 100.07 & 99.31 & 99.60 \\
\hline \multicolumn{4}{|c|}{ Trace elements (ppm) } \\
\hline $\mathrm{Sc}$ & 46.5 & 50.2 & 11.0 \\
\hline V & 99.8 & 103.3 & 120.0 \\
\hline $\mathrm{Cr}$ & 316.1 & 11.1 & 8.0 \\
\hline Co & 20.8 & 12.8 & 10.0 \\
\hline $\mathrm{N}$ & 85.3 & 20.6 & 6.0 \\
\hline $\mathrm{Cu}$ & 17.2 & 27.7 & - \\
\hline $\mathrm{Zn}$ & 74.7 & 71.1 & - \\
\hline Mo & 0.7 & 0.8 & - \\
\hline $\mathrm{Rb}$ & 29.7 & 39.9 & 12.5 \\
\hline
\end{tabular}




\begin{tabular}{|c|c|c|c|}
\hline Sample & Bal2 & Pin Dac & phM5 \\
\hline $\mathrm{Ba}$ & 468.7 & 444.1 & 193.0 \\
\hline Th & 3.4 & 4.3 & 1.2 \\
\hline U & 1.1 & 1.3 & - \\
\hline $\mathrm{Nb}$ & 2.0 & 4.0 & 2.5 \\
\hline $\mathrm{Ta}$ & 0.1 & 0.3 & - \\
\hline $\mathrm{U}$ & 11.9 & 16.7 & 6.6 \\
\hline $\mathrm{Nb}$ & 21.5 & 30.6 & 15.0 \\
\hline $\mathrm{Pb}$ & 11.0 & 11.3 & - \\
\hline $\operatorname{Pr}$ & 2.7 & 3.7 & - \\
\hline $\mathrm{Sr}$ & 1058.5 & 577.1 & 375.0 \\
\hline $\mathrm{Nd}$ & 12.7 & 15.5 & 9.4 \\
\hline $\mathrm{Sm}$ & 2.5 & 3.0 & 2.4 \\
\hline $\mathrm{Zr}$ & 87.0 & 105.8 & 3.0 \\
\hline $\mathrm{Hf}$ & 2.5 & 2.8 & - \\
\hline $\mathrm{Eu}$ & 87.0 & 0.9 & 0.8 \\
\hline $\mathrm{Sn}$ & 2.5 & 2.8 & - \\
\hline $\mathrm{Gd}$ & 2.0 & 2.6 & 2.7 \\
\hline $\mathrm{Tb}$ & 0.2 & 0.4 & - \\
\hline Dy & 1.2 & 2.3 & 2.8 \\
\hline Y & 5.4 & 13.6 & 18.0 \\
\hline Но & 0.2 & 0.5 & - \\
\hline $\mathrm{Er}$ & 0.5 & 1.3 & 1.8 \\
\hline $\mathrm{Tm}$ & 0.1 & 0.2 & - \\
\hline $\mathrm{Yb}$ & 0.4 & 1.3 & 1.7 \\
\hline $\mathrm{Lu}$ & 0.1 & 0.2 & - \\
\hline $\mathrm{Sr} / \mathrm{Y}$ & 197.8 & 42.4 & 20.8 \\
\hline $\mathrm{Au}(\mathrm{ppb})$ & 38 & 12 & 29 \\
\hline $\mathrm{S}(\mathrm{ppm})$ & bdl & bdl & bdl \\
\hline
\end{tabular}




\begin{tabular}{|c|c|c|c|}
\hline Sample & Bal2 & Pin Dac & phM5 \\
\hline Texture & Porphyric Microlithic & Porphyric & Porphyric Microlithic \\
\hline \multirow[t]{8}{*}{ Phenocrystals } & Plagioclase & Plagioclase & Plagioclase \\
\hline & Green Hornblende & Hornblende (Cummingtonite) & Ilmenite Magnetite \\
\hline & Ilmenite & & \\
\hline & Magnetite & Ilmenite & Green Hornblende \\
\hline & & Magnetite & Quartz in cracks \\
\hline & & Biotite & \\
\hline & & Quartz & \\
\hline & & Anhydrite & \\
\hline \multirow[t]{5}{*}{ Matrix } & Plagioclase & Class & Brown biotite \\
\hline & Green Hornblende & & Ilmenite Magnetite \\
\hline & Ilmenite & & \\
\hline & Magnetite & & Included apatites \\
\hline & & & Plagioclase \\
\hline
\end{tabular}

Major (including Si) and rare earth elements were measured by ICP-AES in Brest, France using the techniques described in Cotten et al. (1995). Additional trace elements (including $\mathrm{Au}$ ) were determined by ICP-MS in Toulouse, France using the methods described by Aries et al. (2000). Sulfur in starting materials (double-melting glass) was measured by EPMA in Taipai, Taiwan; bdl, below detection limit (here, $<30 \mathrm{ppm}$ ); see text for details. Ages were taken from Bellon and Yumul (2001) for Bal2, and from Bellon and Yumul (2000) for PhM5. Dacite Pin Dac was erupted in 1991.

Table 2. Summary for experimental data for sulfur-free charges. 


\begin{tabular}{|c|c|c|c|c|c|c|c|c|c|c|}
\hline Charges & $\begin{array}{l}\mathrm{H}_{2} \mathrm{O} \\
\text { glass }\end{array}$ & $\begin{array}{l}\text { Au } \\
\text { glass }\end{array}$ & $\begin{array}{l}\mathbf{L O D}_{\min -} \\
\max (n)\end{array}$ & $\begin{array}{l}\log \\
X_{\mathrm{Au}}\end{array}$ & $\mathbf{a H}_{2} \mathrm{O}$ & $\begin{array}{l}\log \\
f \mathrm{H}_{2} \mathrm{O}\end{array}$ & $\begin{array}{l}\log \\
\mathrm{fO}_{2}\end{array}$ & $\Delta \mathbf{N N O}$ & $\Delta \mathrm{FeO}$ & Phases \\
\hline \multicolumn{11}{|c|}{ Run no. $l: P=4060$ bar, $T=1000^{\circ} \mathrm{C}, f H_{3}=1.97$ bar, $X_{N i}=0.168, t=112.5 \mathrm{~h}$} \\
\hline \multicolumn{11}{|c|}{ Com position Pin Dac } \\
\hline $\mathrm{C} 1 \mathrm{~A}$ & $\begin{array}{l}8.36 \\
(0.26)\end{array}$ & $\begin{array}{l}61 \\
(4)\end{array}$ & $3-6(3)$ & -7.82 & 1.00 & 3.61 & -7.84 & 2.41 & -8.4 & $\begin{array}{l}\text { Gl (100) } \\
\text { Vap }\end{array}$ \\
\hline $\mathrm{C} 2 \mathrm{~A}$ & $\begin{array}{l}6.85 \\
(0.46)\end{array}$ & $\begin{array}{l}51 \\
(4)\end{array}$ & $4-7(3)$ & -7.87 & 0.89 & 3.49 & -7.95 & 2.31 & -8.7 & Gl (100) \\
\hline $\mathrm{C} 3 \mathrm{~A}$ & $\begin{array}{l}5.52 \\
(0.08)\end{array}$ & $\begin{array}{l}44 \\
(22)\end{array}$ & $3-4(3)$ & -7.92 & 0.73 & 3.35 & -8.12 & 2.13 & -7.8 & $\begin{array}{l}\text { Gl (99); } \\
\text { Cpx (1) }\end{array}$ \\
\hline $\mathrm{C} 8 \mathrm{~A}$ & $\begin{array}{l}5.85 \\
(0.16)\end{array}$ & $\begin{array}{l}79 \\
(2)\end{array}$ & $4-10(3)$ & -7.72 & 0.77 & 3.39 & -8.08 & 2.18 & -8.9 & Gl (100) \\
\hline \multicolumn{11}{|c|}{ Run no. 2: $P=4045 \mathrm{bar}, \mathrm{T}=1000^{\circ} \mathrm{C}, \mathrm{fH}_{2}=3.95 \mathrm{bar}, \mathrm{XNi}=0.250, t=113.5 \mathrm{~h}$} \\
\hline \multicolumn{11}{|c|}{ Composition Bal2 } \\
\hline $\mathrm{C} 1 \mathrm{~B}$ & $\begin{array}{l}8.28 . \\
(0.60)\end{array}$ & $\begin{array}{l}101 \\
(2)\end{array}$ & $9-12(3)$ & -7.60 & 1.00 & 3.60 & -845 & 1.80 & -2.2 & $\begin{array}{l}\text { Gl (99); } \\
\text { Cpx (1); } \\
\text { Vap }\end{array}$ \\
\hline $\mathrm{C} 2 \mathrm{~B}$ & $\begin{array}{l}6.70 . \\
(0.52)\end{array}$ & $\begin{array}{l}87 \\
(18)\end{array}$ & $8-10(3)$ & -7.64 & 0.86 & 3.47 & -8.58 & 1.67 & -6.0 & $\begin{array}{l}\text { Gl (97); } \\
\text { Cpx (3) }\end{array}$ \\
\hline $\mathrm{C} 3 \mathrm{~B}$ & $\begin{array}{l}5.33 . \\
(0.32)\end{array}$ & $\begin{array}{l}80 \\
(12)\end{array}$ & $5-5(3)$ & -7.66 & 0.69 & 3.32 & -8.78 & 1.48 & -9.3 & $\begin{array}{l}\text { Gl (95); } \\
\text { Cpx (5) }\end{array}$ \\
\hline \multicolumn{11}{|c|}{ Composition PhMS } \\
\hline C4B & $\begin{array}{l}7.4 \\
(0.04)\end{array}$ & $\begin{array}{l}80 \\
(8)\end{array}$ & $4-8(3)$ & -7.68 & 0.94 & 3.54 & -8.51 & 1.74 & -6.4 & Gl (100) \\
\hline C5B & $\begin{array}{l}7.15 \\
(0.80)\end{array}$ & $\begin{array}{l}61 \\
(6)\end{array}$ & $5-8(3)$ & -7.80 & 0.90 & 3.52 & -8.54 & 1.71 & -7.3 & Gl (100) \\
\hline C6B & $\begin{array}{l}5.58 \\
(0.92)\end{array}$ & $\begin{array}{l}53 \\
(8)\end{array}$ & $4-7(3)$ & -7.84 & 0.72 & 3.36 & -8.74 & 1.52 & -7.1 & Gl (100) \\
\hline \multicolumn{11}{|c|}{ Run no. $10: P=4000$ bar, $T=1000^{\circ} \mathrm{C}, f H_{2}=1.20$ bar, $X_{N i}=0.145, t=95 \mathrm{~h}$} \\
\hline \multicolumn{11}{|c|}{ Composition Pin Dac } \\
\hline $\mathrm{C} 1 \mathrm{~J}$ & $\begin{array}{l}8.39 \\
(0.50)\end{array}$ & $\begin{array}{l}237 \\
(20)\end{array}$ & $\begin{array}{l}24-27 \\
(4)\end{array}$ & -7.23 & 1.00 & 3.62 & -7.64 & 2.62 & +1.7 & $\begin{array}{l}\text { Gl (99): } \\
\text { Mgt (1); }\end{array}$ \\
\hline
\end{tabular}




\begin{tabular}{|c|c|c|c|c|c|c|c|c|c|c|}
\hline Charges & $\begin{array}{l}\mathrm{H}_{2} \mathrm{O} \\
\text { glass }\end{array}$ & $\begin{array}{l}\text { Au } \\
\text { glass }\end{array}$ & $\begin{array}{l}\text { LOD }_{\min -} \\
\max (n)\end{array}$ & $\begin{array}{l}\log \\
X_{\mathrm{Au}}\end{array}$ & $a \mathrm{H}_{2} \mathrm{O}$ & $\begin{array}{l}\log \\
\mathrm{fH}_{2} \mathrm{O}\end{array}$ & $\begin{array}{l}\log \\
\mathrm{fO}_{2}\end{array}$ & $\Delta \mathbf{N N O}$ & $\Delta \mathrm{FeO}$ & Phases \\
\hline & & & & & & & & & & Vap \\
\hline $\mathrm{C} 2 \mathrm{~J}$ & $\begin{array}{l}6.32 \\
(0.22)\end{array}$ & $\begin{array}{l}198 \\
(38)\end{array}$ & $\begin{array}{l}10-14 \\
(3)\end{array}$ & -7.28 & 1.82 & 3.44 & -7.81 & 2.44 & -0.3 & $\begin{array}{l}\text { Gl (99); } \\
\text { Mgt (1); } \\
\text { Au- } \\
\text { nuggets }\end{array}$ \\
\hline \multicolumn{11}{|c|}{ Composition Bal2 } \\
\hline $\mathrm{C} 3 \mathrm{~J}$ & $\begin{array}{l}8.33 \\
(0.28)\end{array}$ & $\begin{array}{l}236 \\
(36)\end{array}$ & $\begin{array}{l}27-59 \\
(5)\end{array}$ & -7.23 & 1.00 & 3.61 & -764 & 2.62 & +3.2 & $\begin{array}{l}\text { Gl } \\
\text { (99);Mgt } \\
\text { (1);Vap }\end{array}$ \\
\hline $\mathrm{C} 4 \mathrm{~J}$ & $\begin{array}{l}6.34 \\
(0.24)\end{array}$ & $\begin{array}{l}186 \\
(30)\end{array}$ & $\begin{array}{l}24-33 \\
(4)\end{array}$ & -7.31 & 0.81 & 3.44 & -7.82 & 2.11 & +1.3 & $\begin{array}{l}\text { Gl } \\
\text { (98);Cpx } \\
\text { (2); Mgt }\end{array}$ \\
\hline \multicolumn{11}{|c|}{ Composition PhM5 } \\
\hline $\mathrm{C} 5 \mathrm{~J}$ & $\begin{array}{l}4.13 \\
(0.10)\end{array}$ & $\begin{array}{l}183 \\
(16)\end{array}$ & $9-18(3)$ & -7.28 & 0.49 & 3.16 & -8.25 & 2.00 & -2.6 & $\begin{array}{l}\text { Gl } \\
\text { (99);Mgl } \\
\text { (1);Au- } \\
\text { nuggels }\end{array}$ \\
\hline $\mathrm{C} 6 \mathrm{~J}$ & $\begin{array}{l}6.98 \\
(0.46)\end{array}$ & $\begin{array}{l}240 \\
(42)\end{array}$ & $\begin{array}{l}13-35 \\
(5)\end{array}$ & -7.20 & 0.87 & 3.51 & -7.76 & 2.50 & -1.5 & $\begin{array}{l}\text { Gl } \\
\text { (99);Mgt } \\
\text { (1);Au- } \\
\text { nuggets }\end{array}$ \\
\hline \multicolumn{11}{|c|}{ Run no. $11: P=4000$ bar, $T=1090^{\circ} \mathrm{C}, \mathrm{fH}_{2}=143.57 \mathrm{bar}, X_{C o}=0.639, t>117 \mathrm{~h}$} \\
\hline \multicolumn{11}{|c|}{ Composition Pin Dac } \\
\hline $\mathrm{C} 2 \mathrm{~K}$ & $\begin{array}{l}5.37 \\
(0.02)\end{array}$ & $\begin{array}{l}33 \\
(18)\end{array}$ & $7-34(6)$ & -8.05 & 0.71 & 3.32 & -11.88 & -1.62 & -31.8 & $\begin{array}{l}\text { Gl (99); } \\
\text { Cpx (1) }\end{array}$ \\
\hline \multicolumn{11}{|c|}{ Composition Bal2 } \\
\hline $\mathrm{C} 3 \mathrm{~K}$ & $\begin{array}{l}9.22 \\
(0.56)\end{array}$ & $\begin{array}{l}50 \\
(10)\end{array}$ & $\begin{array}{l}13-16 \\
(4)\end{array}$ & -7.91 & 1.00 & 3.66 & -11.59 & -1.33 & -19.3 & $\begin{array}{l}\text { Gl (99); } \\
\text { Cpx (1); } \\
\text { Vap }\end{array}$ \\
\hline $\mathrm{C} 4 \mathrm{~K}$ & $\begin{array}{l}7.46 \\
(0.16)\end{array}$ & $\begin{array}{l}50 \\
(32)\end{array}$ & $8-20(4)$ & -7.89 & 0.95 & 3.53 & -11.63 & -1.37 & -23.1 & $\begin{array}{l}\text { Gl (98); } \\
\text { Cpx (2) }\end{array}$ \\
\hline
\end{tabular}




\begin{tabular}{|c|c|c|c|c|c|c|c|c|c|c|}
\hline Charges & $\begin{array}{l}\mathrm{H}_{2} \mathrm{O} \\
\text { glass }\end{array}$ & $\begin{array}{l}\text { Au } \\
\text { glass }\end{array}$ & $\begin{array}{l}\text { LOD }_{\min -} \\
\max (n)\end{array}$ & $\begin{array}{l}\log \\
X_{\mathrm{Au}}\end{array}$ & $a \mathrm{H}_{2} \mathrm{O}$ & $\begin{array}{l}\log \\
f \mathrm{H}_{2} \mathrm{O}\end{array}$ & $\begin{array}{l}\log \\
\mathrm{fO}_{2}\end{array}$ & $\Delta \mathrm{NNO}$ & $\Delta \mathrm{FeO}$ & Phases \\
\hline \multicolumn{11}{|c|}{ Composition PhM5 } \\
\hline $\mathrm{C} 5 \mathrm{~K}$ & $\begin{array}{l}8.80 \\
(0.24)\end{array}$ & $\begin{array}{l}55 \\
(24)\end{array}$ & $\begin{array}{l}10-17 \\
(4)\end{array}$ & -7.86 & 1.00 & 3.63 & -11.59 & -1.33 & -21.0 & $\begin{array}{l}\text { Gl } \\
(100) ; \\
\text { Vap }\end{array}$ \\
\hline
\end{tabular}

$\mathrm{H}_{2} \mathrm{O}$ glass in $\mathrm{wt} \%( \pm 2 \sigma)$; Au glass in ppb $( \pm 2 \sigma)$. LOD, limit of detection (in ppb) for Au glass; $n$ is the number of $\mathrm{Au}$ glass analyses per charge. Note that the $\mathrm{LOD}_{\min }\left(\mathrm{LOD}_{\max }\right)$ is not necessarily relative to the lowest (highest) melt gold content measured in the charge; LOD is maily controlled by the width of the signal part used for calculations (see Fig. 2). Log $X_{\mathrm{Au}}$ : logarithm of the gold molar fraction in the experimental silicate glass. $\mathrm{X}_{\mathrm{Ni}}$ (runs 1, 2, 10) and $\mathrm{X}_{\mathrm{Co}}$ (run 11) are the average proportions of $\mathrm{Ni}$ and $\mathrm{Co}$, respectively, in solid sensor alloys (see Sections 3.2. and 3.4.1 for details). $t$ is the experimental duration in hours. $f \mathrm{H}_{2}$ are calculated from the $\mathrm{fO}_{2}$ in the sensor capsule ([Pownceby and O'Neill, 1994] and [Taylor et al., 1992]), taking $f \mathrm{H}_{2} \mathrm{O}=f^{\circ} \mathrm{H}_{2} \mathrm{O} . \Delta \mathrm{NNO}: f \mathrm{O}_{2}-f \mathrm{O}_{2}$ of the $\mathrm{NNO}$ equilibrium at the same pressure and temperature. $\triangle \mathrm{FeO}$ (in $\mathrm{wt} \%$ ): proportion of $\mathrm{Fe}$ lost during experiment $(=100 \times([\mathrm{FeO}]$ glass $)+$ crystals $-[\mathrm{FeO}]$ starting glass $) . \mathrm{Gl}$, glass; Cpx, clinopyroxine; Mgt, magnetite; Vap, vapour phase; Au-nuggets, gold micro-crystals. Avapourphase is systematically indicated for any charge at water saturation (i.e., $a \mathrm{H}_{2} \mathrm{O}=1$ ). Phase proportions (in $w t \%$ ) calculated by mass balance. 
Table 3. Summary for experimental data for sulfur bearing charges of Pin Dac composition.

\begin{tabular}{|c|c|c|c|c|c|c|c|c|c|c|c|c|c|}
\hline $\begin{array}{l}\text { Char } \\
\text { ges }\end{array}$ & $\begin{array}{l}\mathbf{H}_{2} \\
\mathbf{O} \\
\text { glas } \\
\mathbf{S}\end{array}$ & $\begin{array}{l}\text { S } \\
\text { glas } \\
\mathbf{S}\end{array}$ & $\begin{array}{l}\text { Au } \\
\text { gla } \\
\text { ss }\end{array}$ & $\begin{array}{l}\text { LOD } \\
\min -\max \\
(n)\end{array}$ & $\begin{array}{l}\log \\
X_{\mathrm{Au}}\end{array}$ & $\begin{array}{l}a \mathbf{H}_{2} \\
\mathbf{O}\end{array}$ & $\begin{array}{l}\log \\
\mathrm{fH}_{2} \\
\mathrm{O}^{\circ}\end{array}$ & $\begin{array}{l}\log \\
\mathrm{fO}_{2}\end{array}$ & $\begin{array}{l}\Delta \mathbf{N N} \\
\mathbf{O}\end{array}$ & $\begin{array}{l}\log \\
f S_{2}\end{array}$ & $\begin{array}{l}10 \\
g \\
f S \\
O_{2}\end{array}$ & $\begin{array}{l}\log \\
f H_{2} \\
S\end{array}$ & $\begin{array}{l}\text { Phase } \\
\text { s }\end{array}$ \\
\hline \multicolumn{14}{|c|}{ Run No.5: $P=4110$ bar, $T=995{ }^{\circ} \mathrm{C}, f H 2=91.38$ bar, $X C o=0.455, t=116 h$} \\
\hline $\mathrm{C} 1 \mathrm{E}$ & $\begin{array}{l}8.03 \\
(1.0 \\
4)\end{array}$ & $\begin{array}{l}957 \\
(162 \\
6)\end{array}$ & $\begin{array}{l}425 \\
3 \\
(35 \\
6)\end{array}$ & $\begin{array}{l}8-8 \\
(4)\end{array}$ & $\begin{array}{l}-5 . \\
97\end{array}$ & 0.99 & 3.57 & $\begin{array}{l}-11 \\
26\end{array}$ & $\begin{array}{l}-1.0 \\
1\end{array}$ & $\begin{array}{l}1.5 \\
0\end{array}$ & $\begin{array}{l}0.6 \\
0\end{array}$ & $\begin{array}{l}3.8 \\
1\end{array}$ & $\begin{array}{l}\text { Gl } \\
(97) ; \\
\text { Pyrrh } \\
(3) ; \\
\text { Vap }\end{array}$ \\
\hline $\mathrm{C} 2 \mathrm{E}$ & $\begin{array}{l}6.19 \\
(0.4 \\
2)\end{array}$ & $\begin{array}{l}570 \\
(188 \\
)\end{array}$ & $\begin{array}{l}168 \\
6 \\
(31 \\
2)\end{array}$ & $\begin{array}{l}6-8 \\
(4)\end{array}$ & $\begin{array}{l}-6 \\
35\end{array}$ & 0.79 & 3.42 & $\begin{array}{l}-11 \\
46\end{array}$ & $\begin{array}{l}-1.2 \\
1\end{array}$ & $\begin{array}{l}1.1 \\
5\end{array}$ & $\begin{array}{l}0.2 \\
2\end{array}$ & $\begin{array}{l}3.5 \\
7\end{array}$ & $\begin{array}{l}\text { Gl } \\
(99) ; \\
\text { Pyrrh } \\
(1) ; \\
\text { Au- } \\
\text { nuggc } \\
\text { ts; } \\
\text { Vap }\end{array}$ \\
\hline C3E & $\begin{array}{l}5.86 \\
(0.1 \\
6)\end{array}$ & $\begin{array}{l}548 \\
(116 \\
)\end{array}$ & $\begin{array}{l}120 \\
9 \\
(22 \\
8)\end{array}$ & $\begin{array}{l}6-22 \\
(6)\end{array}$ & $\begin{array}{l}-6 \\
49\end{array}$ & 0.74 & 3.38 & $\begin{array}{l}-11 \\
52\end{array}$ & $\begin{array}{l}-1.2 \\
6\end{array}$ & $\begin{array}{l}1.0 \\
0\end{array}$ & $\begin{array}{l}0.1 \\
0\end{array}$ & $\begin{array}{l}3.4 \\
8\end{array}$ & $\begin{array}{l}\text { Gl } \\
(97) ; \\
\text { Pyrrh } \\
(3) ; \\
\text { Vap }\end{array}$ \\
\hline \multicolumn{14}{|c|}{ Run No.6: $P=3950$ bar, $T=1000{ }^{\circ} \mathrm{C}, f H 2=93.68 \mathrm{bar}, \mathrm{XCo}=0.471, t=136 \mathrm{~h}$} \\
\hline $\mathrm{C} 1 \mathrm{~F}$ & $\begin{array}{l}8.03 \\
(0.9 \\
8)\end{array}$ & $\begin{array}{l}739 \\
(90)\end{array}$ & $\begin{array}{l}250 \\
6 \\
(82 \\
)\end{array}$ & $\begin{array}{l}5-6 \\
(3)\end{array}$ & $\begin{array}{l}-6 . \\
20\end{array}$ & 1.00 & 3.56 & $\begin{array}{l}-11 \\
23\end{array}$ & $\begin{array}{l}-0.9 \\
7\end{array}$ & $\begin{array}{l}2.0 \\
3\end{array}$ & $\begin{array}{l}0.9 \\
0\end{array}$ & $\begin{array}{l}4.0 \\
5\end{array}$ & $\begin{array}{l}\text { Gl } \\
(96) ; \\
\text { Pyrrh } \\
(4) ; \\
\text { Vap }\end{array}$ \\
\hline $\mathrm{C} 2 \mathrm{~F}$ & $\begin{array}{l}7.31 \\
(0.7 \\
0)\end{array}$ & $\begin{array}{l}702 \\
(128 \\
)\end{array}$ & $\begin{array}{l}214 \\
7 \\
(17 \\
0)\end{array}$ & $\begin{array}{l}7-21 \\
(3)\end{array}$ & $\begin{array}{l}-6 . \\
26\end{array}$ & 0.92 & 3.51 & $\begin{array}{l}-11 \\
30\end{array}$ & $\begin{array}{l}-1.0 \\
5\end{array}$ & $\begin{array}{l}1.8 \\
8\end{array}$ & $\begin{array}{l}0.7 \\
5\end{array}$ & $\begin{array}{l}3.9 \\
6\end{array}$ & $\begin{array}{l}\text { Gl } \\
\text { (96): } \\
\text { Pyrrh } \\
(4): \\
\text { Au- } \\
\text { nugge } \\
\text { ts; } \\
\text { Vap }\end{array}$ \\
\hline $\mathrm{C} 3 \mathrm{~F}$ & $\begin{array}{l}7.70 \\
(1.1 \\
0)\end{array}$ & $\begin{array}{l}712 \\
(96)\end{array}$ & $\begin{array}{l}208 \\
6 \\
(22\end{array}$ & $\begin{array}{l}9-41 \\
(6)\end{array}$ & $\begin{array}{c}-6 \\
27\end{array}$ & 0.97 & 3.54 & $\begin{array}{l}-11 \\
26\end{array}$ & $\begin{array}{l}-1.0 \\
0\end{array}$ & $\begin{array}{l}1.8 \\
2\end{array}$ & $\begin{array}{l}0.7 \\
7\end{array}$ & $\begin{array}{l}3.9 \\
4\end{array}$ & Gl ( \\
\hline
\end{tabular}




\begin{tabular}{|c|c|c|c|c|c|c|c|c|c|c|c|c|c|}
\hline $\begin{array}{l}\text { Char } \\
\text { ges }\end{array}$ & $\begin{array}{l}\mathbf{H}_{2} \\
\mathbf{O} \\
\text { glas } \\
\text { S }\end{array}$ & $\begin{array}{l}\text { S } \\
\text { glas } \\
\text { S }\end{array}$ & $\begin{array}{l}\text { Au } \\
\text { gla } \\
\text { ss }\end{array}$ & $\begin{array}{l}\text { LOD } \\
\min -\max \\
(n)\end{array}$ & $\begin{array}{l}\log \\
X_{\mathrm{Au}}\end{array}$ & $\begin{array}{l}a \mathbf{H}_{2} \\
\mathbf{O}\end{array}$ & $\begin{array}{l}\log \\
\mathrm{fH}_{2} \\
\mathrm{O}^{\circ}\end{array}$ & $\begin{array}{l}\log \\
f O_{2}\end{array}$ & $\begin{array}{l}\Delta \mathbf{N N} \\
\mathbf{O}\end{array}$ & $\begin{array}{l}\log \\
f S_{2}\end{array}$ & $\begin{array}{l}10 \\
\mathrm{~g} \\
\mathrm{fS} \\
\mathrm{O}_{2}\end{array}$ & $\begin{array}{l}\log \\
f \mathrm{H}_{2} \\
\mathrm{~S}\end{array}$ & $\begin{array}{l}\text { Phase } \\
\text { s }\end{array}$ \\
\hline & & & 2) & & & & & & & & & & \\
\hline
\end{tabular}

$\mathrm{H}_{2} \mathrm{O}$ glass in $\mathrm{wt} \%( \pm 2 \sigma)$; S glass in ppm $( \pm 2 \sigma)$; Au glass in ppb $( \pm 2 \sigma)$. LOD, limit of detection (in ppb) for Au glass; $n$ is the number of Au glass analyses per charge. Note that the $\mathrm{LOD}_{\text {min }}$ $\left(\mathrm{LOD}_{\max }\right)$ is not necessarily relative to the lowest (highest) melt gold content measured in the charge; LOD is maily controlled by the width of the signal part used for calculations (see Fig. 2). $\log X_{\mathrm{Au}}$ : logarithm of the gold molar fraction in the experimental silicate glass. $X_{\mathrm{Co}}$ is the average proportion of Co in solid sensor alloys (see text for details). $t$ is the experimental duration in hours. $f \mathrm{H}_{2}$ are calculated from the $f \mathrm{O}_{2}$ in the sensor capsule (Taylor et al., 1992), taking $f \mathrm{H}_{2} \mathrm{O}=f^{\circ} \mathrm{H}_{2} \mathrm{O} . \Delta \mathrm{NNO}: f \mathrm{O}_{2}-f \mathrm{O}_{2}$ of the $\mathrm{NNO}$ equilibrium at the same pressure and temperature. $\log f \mathrm{~S}_{2}$ calculated from pyrrhotite composition (Froese and Gunter, 1976); $\log$ $f \mathrm{SO}_{2}$ and $\log \mathrm{fH}_{2} \mathrm{~S}$ calculated from Ohmoto and Kerrick (1977). Gl, glass; Cpx, clinopyroxine; Mgt, magnetite; Vap, vapour phase; Au-nuggets, gold micro-crystals. Avapourphase is systematically indicated for any charge at water saturation (i.e., $a \mathrm{H}_{2} \mathrm{O}=1$ ). Phase proportions (in $\mathrm{wt} \%$ ) calculated by mass balance. the large heterogeneity of glass $\mathrm{S}$ content in charge $\mathrm{C} 1 \mathrm{E}$ is thoughto be due to a quench failure. 

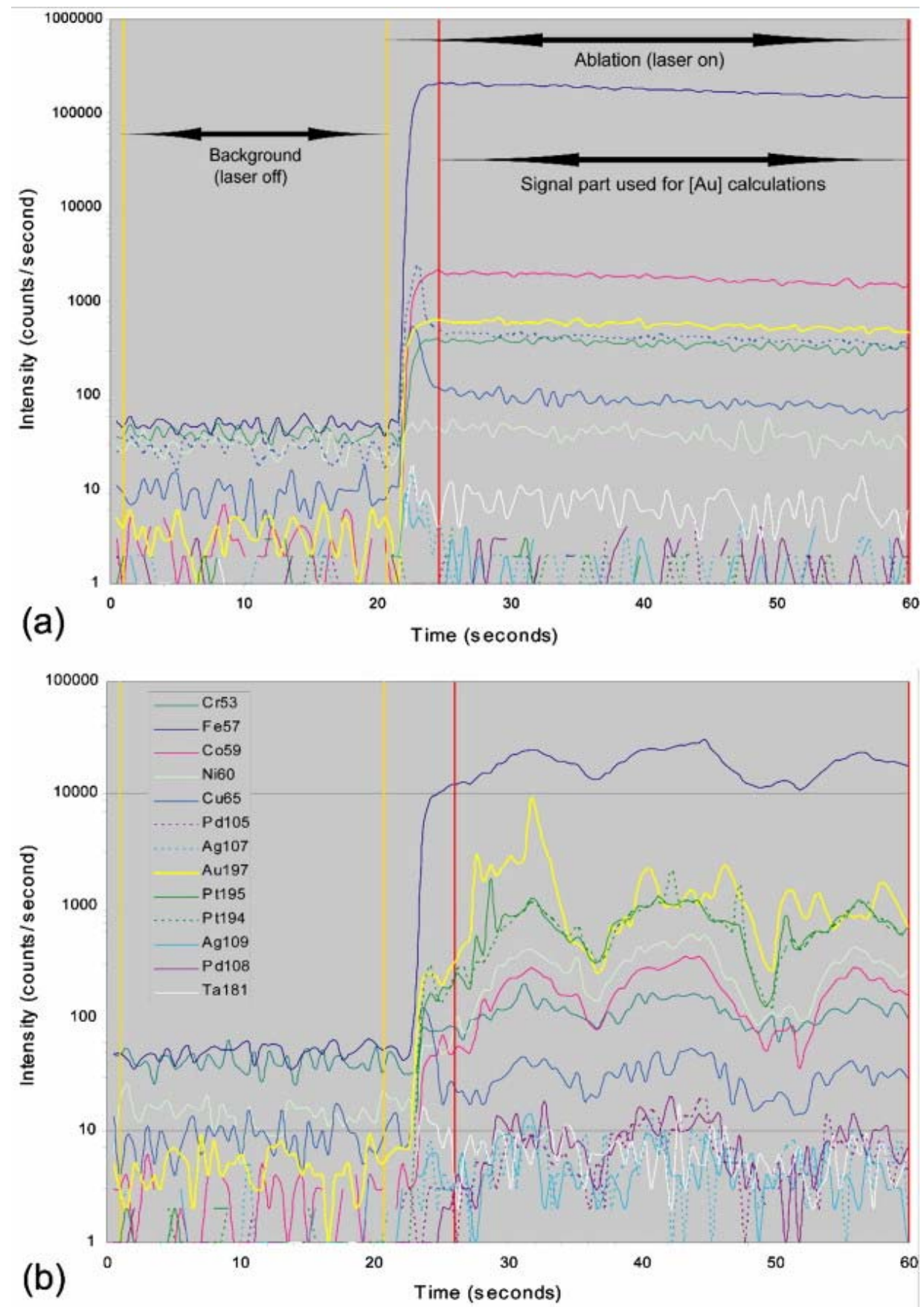

Fig. 2.

Examples of ablation signals recorded during analysis of our experimental glasses. Numbers of counts (in logarithmic scale) are plotted versus time (in seconds). The yellow vertical lines delimit the background part of the spectrum, before ablation. Metal concentrations are calculated by using a manually-defined window in the ablation signal, delimited by the red vertical lines. In (a), most of the ablation curves are well defined and roughly flat, and the metal glass concentrations are calculated by considering the whole part of the ablation signal. Same legend than in (b), which represents an example of ablation signal with metal concentration spikes most probably related to the presence of sulfide crystals in the analyzed glass (even Fe signal is correlated). In other cases, a smaller number of metals show spikes, typically $\mathrm{Au}+\mathrm{Pt}+(\mathrm{Cr}, \mathrm{Co}, \mathrm{Ni}, \mathrm{Cu})$, suggesting the presence of Au-nuggets and/or $\mathrm{Au}-\mathrm{Pt}$ extensive solid solutions equilibrated with melt. 

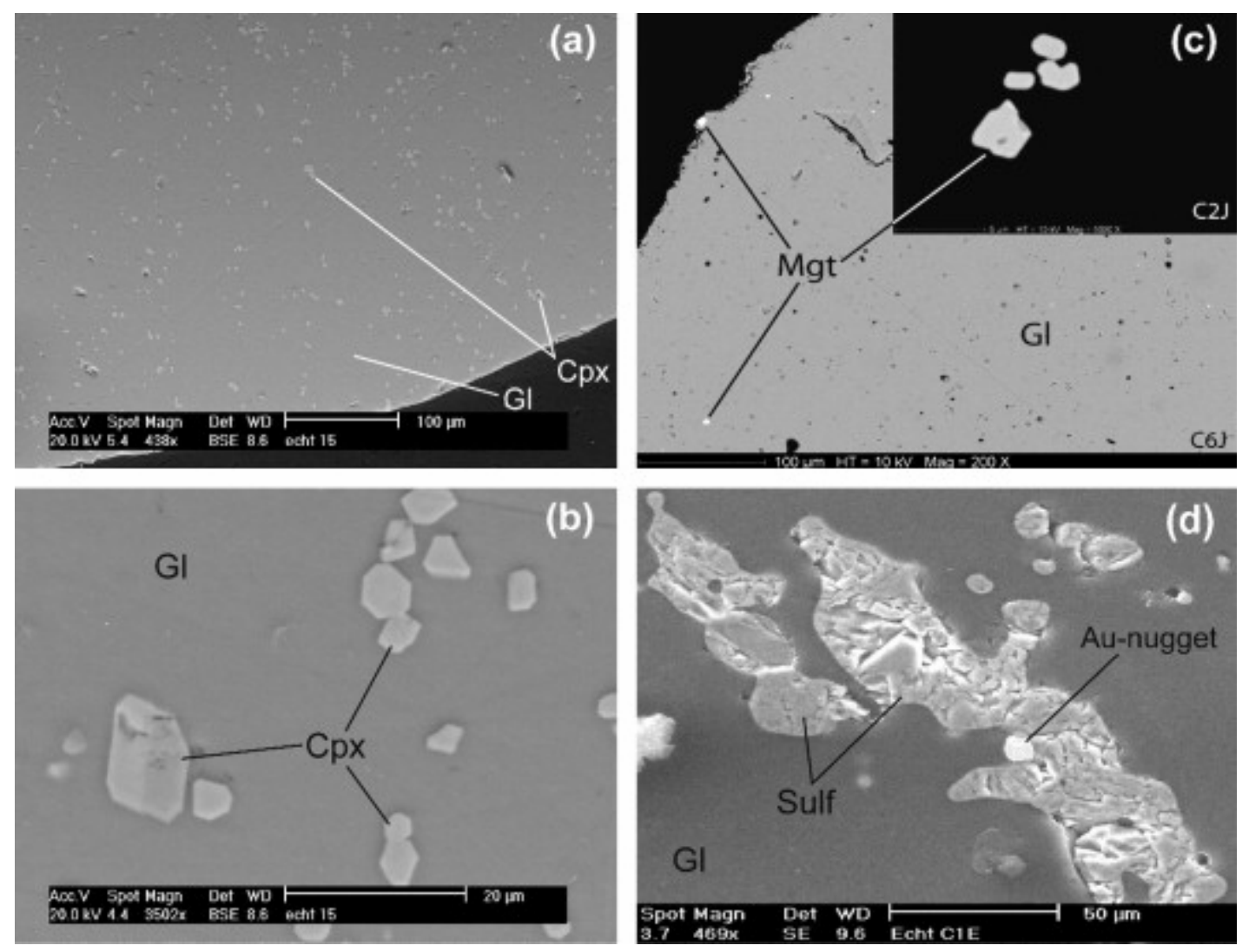

Fig. 3.

(a) SEM image (charge C3B, run no. 2) of a charge representative of the S-free experiments. Note the homogeneous distribution of clinopyroxenes in the glass. (b) Detail of (a) showing the typical size of Cpx crystals. Note also the lack of chemical zonation in Cpx, suggesting attainment of crystal/liquid equilibrium. (c) SEM images of experimental charges C6J and $\mathrm{C} 2 \mathrm{~J}$ (run no. 10) showing micro-crystals of magnetite at equilibrium with the surrounding silicate glass. (d) SEM detail of the charge C2E (run no. 5) showing a gold nugget in close spatial association with a pyrrhotite crystal. The size $(\sim 10 \mu \mathrm{m})$, the texture (i.e., spherical shape) and the location of this Au-nugget, almost enclosed by the sulfide but still in contact with the melt, suggest that the Au-nuggets are stable phases under our experimental conditions and not gold particles formed during quench. Cpx, clinopyroxene; Gl, silicate glass; Sulf, sulphide; Mgt, magnetite; Au-nugget, gold micro-crystal. 
Table 4. Concentrations of major elements (electron microprobe data) in the product glasses for both S-free and S-bearing charges.

\begin{tabular}{|c|c|c|c|c|c|c|c|c|c|}
\hline Charges & C1A & $\mathrm{C} 2 \mathrm{~A}$ & C3A & C8A & C1B & C2B & C3B & C4B & C5B \\
\hline $\mathrm{n}$ & 10 & 10 & 10 & 10 & 10 & 10 & 10 & 10 & 10 \\
\hline $\mathrm{SiO}_{2}$ & $\begin{array}{l}66.29 \\
(0.90)\end{array}$ & $\begin{array}{l}66.17 \\
(0.56)\end{array}$ & $\begin{array}{l}66.18 \\
(0.66)\end{array}$ & $\begin{array}{l}66.20 \\
(0.74)\end{array}$ & $\begin{array}{l}66.82 \\
(0.76)\end{array}$ & $\begin{array}{l}67.11 \\
(0.59)\end{array}$ & $\begin{array}{l}67.33 \\
(0.55)\end{array}$ & $\begin{array}{l}65.37 \\
(0.60)\end{array}$ & $\begin{array}{l}65.25 \\
(0.67)\end{array}$ \\
\hline $\mathrm{Al}_{2} \mathrm{O}_{3}$ & $\begin{array}{l}16.01 \\
(0.22)\end{array}$ & $\begin{array}{l}16.02 \\
(0.46)\end{array}$ & $\begin{array}{l}16.08 \\
(0.34)\end{array}$ & $\begin{array}{l}16.01 \\
(0.33)\end{array}$ & $\begin{array}{l}15.90 \\
(0.34)\end{array}$ & $\begin{array}{l}16.23 \\
(0.41)\end{array}$ & $\begin{array}{l}16.36 \\
(0.17)\end{array}$ & $\begin{array}{l}16.52 \\
(0.25)\end{array}$ & $\begin{array}{l}16.56 \\
(0.24)\end{array}$ \\
\hline $\mathrm{K}_{2} \mathrm{O}$ & $\begin{array}{l}1.62 \\
(0.21)\end{array}$ & $\begin{array}{l}1.61 \\
(0.19)\end{array}$ & $\begin{array}{l}1.59 \\
(0.25)\end{array}$ & $\begin{array}{l}1.64 \\
(0.21)\end{array}$ & $\begin{array}{l}1.82 \\
(0.23)\end{array}$ & $\begin{array}{l}1.88 \\
(0.24)\end{array}$ & $\begin{array}{l}1.92 \\
(0.10)\end{array}$ & $\begin{array}{l}0.69 \\
(0.09)\end{array}$ & $\begin{array}{l}0.67 \\
(0.15)\end{array}$ \\
\hline $\mathrm{Na}_{2} \mathrm{O}$ & $\begin{array}{l}4.63 \\
(0.37)\end{array}$ & $\begin{array}{l}4.66 \\
(0.29)\end{array}$ & $\begin{array}{l}4.82 \\
(0.24)\end{array}$ & $\begin{array}{l}4.69 \\
(0.25)\end{array}$ & $\begin{array}{l}5.07 \\
(0.22)\end{array}$ & $\begin{array}{l}5.25 \\
(0.33)\end{array}$ & $\begin{array}{l}5.45 \\
(0.26)\end{array}$ & $\begin{array}{l}4.56 \\
(0.36)\end{array}$ & $\begin{array}{l}4.61 \\
(0.31)\end{array}$ \\
\hline $\mathrm{CaO}$ & $\begin{array}{l}4.87 \\
(0.29)\end{array}$ & $\begin{array}{l}4.87 \\
(0.34)\end{array}$ & $\begin{array}{l}4.77 \\
(0.34)\end{array}$ & $\begin{array}{l}4.86 \\
(0.28)\end{array}$ & $\begin{array}{l}4.29 \\
(0.19)\end{array}$ & $\begin{array}{l}3.91 \\
(0.27)\end{array}$ & $\begin{array}{l}3.78 \\
(0.22)\end{array}$ & $\begin{array}{l}5.41 \\
(0.32)\end{array}$ & $\begin{array}{l}5.49 \\
(0.36)\end{array}$ \\
\hline $\mathrm{FeO}$ & $\begin{array}{l}3.78 \\
(0.58)\end{array}$ & $\begin{array}{l}3.77 \\
(0.44)\end{array}$ & $\begin{array}{l}3.78 \\
(0.55)\end{array}$ & $\begin{array}{l}3.76 \\
(0.46)\end{array}$ & $\begin{array}{l}3.13 \\
(0.36)\end{array}$ & $\begin{array}{l}2.96 \\
(0.52)\end{array}$ & $\begin{array}{l}2.76 \\
(0.41)\end{array}$ & $\begin{array}{l}5.17 \\
(0.37)\end{array}$ & $\begin{array}{l}5.12 \\
(0.53)\end{array}$ \\
\hline $\mathrm{MnO}$ & $\begin{array}{l}0.08 \\
(0.11)\end{array}$ & $\begin{array}{l}0.09 \\
(0.13)\end{array}$ & $\begin{array}{l}0.09 \\
(0.18)\end{array}$ & $\begin{array}{l}0.10 \\
(0.17)\end{array}$ & $\begin{array}{l}0.06 \\
(0.16)\end{array}$ & $\begin{array}{l}0.07 \\
(0.13)\end{array}$ & $\begin{array}{l}0.06 \\
(0.08)\end{array}$ & $\begin{array}{l}0.12 \\
(0.20)\end{array}$ & $\begin{array}{l}0.09 \\
(0.16)\end{array}$ \\
\hline $\mathrm{MgO}$ & $\begin{array}{l}2.20 \\
(0.07)\end{array}$ & $\begin{array}{l}2.23 \\
(0.10)\end{array}$ & $\begin{array}{l}2.13 \\
(009)\end{array}$ & $\begin{array}{l}2.18 \\
(0.14)\end{array}$ & $\begin{array}{l}2.51(0 \\
21)\end{array}$ & $\begin{array}{l}2.23 \\
(0.26)\end{array}$ & $\begin{array}{l}1.95(0 \\
18)\end{array}$ & $\begin{array}{l}1.67 \\
(0.13)\end{array}$ & $\begin{array}{l}1.69(0 \\
14)\end{array}$ \\
\hline $\mathrm{TiO}_{2}$ & $\begin{array}{l}0.52 \\
(0.13)\end{array}$ & $\begin{array}{l}0.56 \\
(0.11)\end{array}$ & $\begin{array}{l}0.52 \\
(0.10)\end{array}$ & $\begin{array}{l}0.55 \\
(0.10)\end{array}$ & $\begin{array}{l}0.34 \\
(0.09)\end{array}$ & $\begin{array}{l}0.34 \\
(0.09)\end{array}$ & $\begin{array}{l}0.37 \\
(0.13)\end{array}$ & $\begin{array}{l}0.45 \\
(0.09)\end{array}$ & $\begin{array}{l}0.48 \\
(0.13)\end{array}$ \\
\hline $\mathrm{Cr}_{2} \mathrm{O}_{3}$ & $\begin{array}{l}0.00 \\
(0.02)\end{array}$ & $\begin{array}{l}0.04 \\
(0.11)\end{array}$ & $\begin{array}{l}0.03 \\
(0.09)\end{array}$ & $\begin{array}{l}0.02 \\
(0.07)\end{array}$ & $\begin{array}{l}0.04 \\
(0.11)\end{array}$ & $\begin{array}{l}0.02 \\
(0.10)\end{array}$ & $\begin{array}{l}0.02(0 \\
09)\end{array}$ & $\begin{array}{l}0.02 \\
(0.07)\end{array}$ & $\begin{array}{l}0.04 \\
(0.09)\end{array}$ \\
\hline Total & $\begin{array}{l}89.53 \\
(0.76)\end{array}$ & $\begin{array}{l}91.48 \\
(0.77)\end{array}$ & $\begin{array}{l}93.02 \\
\left(\begin{array}{ll}0 & 86\end{array}\right)\end{array}$ & $\begin{array}{l}92.06 \\
(0.84)\end{array}$ & $\begin{array}{l}89.94 \\
(0.86)\end{array}$ & $\begin{array}{l}90.96 \\
(0.96)\end{array}$ & $\begin{array}{l}92.34 \\
(0.74)\end{array}$ & $\begin{array}{l}90.21 \\
(0.85)\end{array}$ & $\begin{array}{l}91.30 \\
(0.81)\end{array}$ \\
\hline Charge & C6B & $\mathrm{C} 1 \mathrm{~J}$ & $\mathrm{C} 2 \mathrm{~J}$ & $\mathrm{C} 3 \mathrm{~J}$ & $\mathrm{C} 4 \mathrm{~J}$ & $\mathrm{C} 5 \mathrm{~J}$ & C6J & $\mathrm{C} 2 \mathrm{~K}$ & $\mathrm{C} 3 \mathrm{~K}$ \\
\hline$n$ & 10 & 13 & 11 & 11 & 11 & 11 & 11 & 13 & 11 \\
\hline $\mathrm{SiO}_{2}$ & $\begin{array}{l}65.39 \\
(0.76)\end{array}$ & $\begin{array}{l}65.62 \\
(1.26)\end{array}$ & $\begin{array}{l}65.67 \\
(0.96)\end{array}$ & $\begin{array}{l}66.39 \\
(1.13)\end{array}$ & $\begin{array}{l}66.53 \\
(0.93)\end{array}$ & $\begin{array}{l}65.13 \\
(2.92)\end{array}$ & $\begin{array}{l}65.14 \\
(0.67)\end{array}$ & $\begin{array}{l}66.19 \\
(1.72)\end{array}$ & $\begin{array}{l}66.85 \\
(0.96)\end{array}$ \\
\hline $\mathrm{Al}_{2} \mathrm{O}_{3}$ & $\begin{array}{l}16.43 \\
(0.49)\end{array}$ & $\begin{array}{l}16.51 \\
(0.39)\end{array}$ & $\begin{array}{l}16.37 \\
(0.30)\end{array}$ & $\begin{array}{l}16.22 \\
(0.35)\end{array}$ & $\begin{array}{l}16.46 \\
(0.33)\end{array}$ & $\begin{array}{l}17.21 \\
(291)\end{array}$ & $\begin{array}{l}17.08 \\
(0.42)\end{array}$ & $\begin{array}{l}16.06 \\
(2.19)\end{array}$ & $\begin{array}{l}1610 \\
(0.60)\end{array}$ \\
\hline $\mathrm{K}_{2} \mathrm{O}$ & $\begin{array}{l}0.68 \\
(0.10)\end{array}$ & $\begin{array}{l}1.61 \\
(0.18)\end{array}$ & $\begin{array}{l}1.61 \\
(0.13)\end{array}$ & $\begin{array}{l}1.95 \\
(0.13)\end{array}$ & $\begin{array}{l}1.93 \\
(0.17)\end{array}$ & $\begin{array}{l}0.68 \\
(0.17)\end{array}$ & $\begin{array}{l}0.65 \\
(0.11)\end{array}$ & $\begin{array}{l}1.63 \\
(0.31)\end{array}$ & $\begin{array}{l}1.99 \\
(0.17)\end{array}$ \\
\hline $\mathrm{Na}_{2} \mathrm{O}$ & 4.62 & 4.35 & 4.53 & 4.91 & 5.12 & 4.47 & 4.35 & 4.77 & 4.S7 \\
\hline
\end{tabular}




\begin{tabular}{|c|c|c|c|c|c|c|c|c|c|}
\hline Charges & C1A & $\mathrm{C} 2 \mathrm{~A}$ & C3A & C8A & C1B & $\mathrm{C} 2 \mathrm{~B}$ & C3B & C4B & C5B \\
\hline & (018) & $(0.16)$ & $(0.22)$ & $(0.32)$ & $(0.23)$ & $(0.27)$ & $(0.20)$ & $(0.58)$ & $(0.27)$ \\
\hline $\mathrm{CaO}$ & $\begin{array}{l}5.45 \\
(0.38)\end{array}$ & $\begin{array}{l}4.91 \\
(0.37)\end{array}$ & $\begin{array}{l}4.86 \\
(0.23)\end{array}$ & $\begin{array}{l}4.33 \\
(0.21)\end{array}$ & $\begin{array}{l}4.13 \\
(0.21)\end{array}$ & $\begin{array}{l}5.49 \\
(1.59)\end{array}$ & $\begin{array}{l}5.47(0 \\
32)\end{array}$ & $\begin{array}{l}5.29 \\
(2.86)\end{array}$ & $\begin{array}{l}4.54 \\
(0.25)\end{array}$ \\
\hline $\mathrm{FeO}$ & $\begin{array}{l}5.14 \\
(0.74)\end{array}$ & $\begin{array}{l}3.91 \\
(0.43)\end{array}$ & $\begin{array}{l}3.84 \\
(0.28)\end{array}$ & $\begin{array}{l}2.98 \\
(0.30)\end{array}$ & $\begin{array}{l}2.88 \\
(0.36)\end{array}$ & $\begin{array}{l}4.68 \\
(0.99)\end{array}$ & $\begin{array}{l}4.91 \\
(0.27)\end{array}$ & $\begin{array}{l}2.69 \\
(0.84)\end{array}$ & $\begin{array}{l}2.33 \\
(0.26)\end{array}$ \\
\hline $\mathrm{MnO}$ & $\begin{array}{l}0.06 \\
(0.11)\end{array}$ & $\begin{array}{l}0.08 \\
(0.15)\end{array}$ & $\begin{array}{l}0.10 \\
(0.13)\end{array}$ & $\begin{array}{l}0.04 \\
(0.09)\end{array}$ & $\begin{array}{l}0.07 \\
(0.12)\end{array}$ & $\begin{array}{l}0.08 \\
(0.14)\end{array}$ & $\begin{array}{l}0.04 \\
(0.09)\end{array}$ & $\begin{array}{l}0.14 \\
(0.19)\end{array}$ & $\begin{array}{l}0.09 \\
(0.11)\end{array}$ \\
\hline $\mathrm{MgO}$ & $\begin{array}{l}168 \\
(0.14)\end{array}$ & $\begin{array}{l}2.46 \\
(0.18)\end{array}$ & $\begin{array}{l}2.45 \\
(0.18)\end{array}$ & $\begin{array}{l}2.84 \\
(0.19)\end{array}$ & $\begin{array}{l}2.51 \\
(0.15)\end{array}$ & $\begin{array}{l}1.84 \\
(0.35)\end{array}$ & $\begin{array}{l}1.85 \\
(0.22)\end{array}$ & $\begin{array}{l}2.70 \\
(2.66)\end{array}$ & $\begin{array}{l}2.85 \\
(0.19)\end{array}$ \\
\hline $\mathrm{TiO}_{2}$ & $\begin{array}{l}0.51 \\
(0.13)\end{array}$ & $\begin{array}{l}0.50 \\
(0.13)\end{array}$ & $\begin{array}{l}0.54 \\
(0.11)\end{array}$ & $\begin{array}{l}0.32 \\
(0.11)\end{array}$ & $\begin{array}{l}0.34 \\
(0.13)\end{array}$ & $\begin{array}{l}0.41 \\
(0.16)\end{array}$ & $\begin{array}{l}0.49 \\
(0.14)\end{array}$ & $\begin{array}{l}0.52 \\
(0.20)\end{array}$ & $\begin{array}{l}0.34 \\
(0.15)\end{array}$ \\
\hline $\mathrm{Cr}_{2} \mathrm{O}_{3}$ & $\begin{array}{l}0.04 \\
(0.12)\end{array}$ & $\begin{array}{l}0.04 \\
(0.11)\end{array}$ & $\begin{array}{l}0.02 \\
(0.08)\end{array}$ & $\begin{array}{l}0.02 \\
(0.06)\end{array}$ & $\begin{array}{l}0.04 \\
(0.12)\end{array}$ & $\begin{array}{l}0.00 \\
(0.02)\end{array}$ & $\begin{array}{l}0.03 \\
(0.08)\end{array}$ & $\begin{array}{l}0.01 \\
(0.04)\end{array}$ & $\begin{array}{l}0.03 \\
(0.08)\end{array}$ \\
\hline Total & $\begin{array}{l}92.87 \\
(1.02)\end{array}$ & $\begin{array}{l}90.11 \\
(1.36)\end{array}$ & $\begin{array}{l}91.86 \\
(1.42)\end{array}$ & $\begin{array}{l}90.52 \\
(1.20)\end{array}$ & $\begin{array}{l}92.15 \\
(1.08)\end{array}$ & $\begin{array}{l}94.21 \\
(1.40)\end{array}$ & $\begin{array}{l}91.32 \\
(1.04)\end{array}$ & $\begin{array}{l}92.57 \\
(2.46)\end{array}$ & $\begin{array}{l}88.70 \\
(0.92)\end{array}$ \\
\hline Charge & $\mathrm{C} 4 \mathrm{~K}$ & $\mathrm{C} 5 \mathrm{~K}$ & C6K & $\mathrm{C} 1 \mathrm{E}$ & $\mathrm{C} 2 \mathrm{E}$ & $\mathrm{C} 3 \mathrm{E}$ & $\mathrm{C} 1 \mathrm{~F}$ & $\mathrm{C} 2 \mathrm{~F}$ & $\mathrm{C} 3 \mathrm{~F}$ \\
\hline$n$ & 10 & 10 & 10 & 12 & 12 & 11 & 10 & 10 & 10 \\
\hline $\mathrm{SiO}_{2}$ & $\begin{array}{l}67.18 \\
(0.90)\end{array}$ & $\begin{array}{l}65.68 \\
(1.28)\end{array}$ & $\begin{array}{l}66.01 \\
(1.08)\end{array}$ & $\begin{array}{l}68.31 \\
(2.09)\end{array}$ & $\begin{array}{l}66.40 \\
(0.78)\end{array}$ & $\begin{array}{l}66.91 \\
(0.96)\end{array}$ & $\begin{array}{l}68.42 \\
(0.89)\end{array}$ & $\begin{array}{l}68.25 \\
(0.71)\end{array}$ & $\begin{array}{l}68.28 \\
(1.32)\end{array}$ \\
\hline $\mathrm{SiO}_{2}$ & $\begin{array}{l}16.41 \\
(0.32)\end{array}$ & $\begin{array}{l}17.06 \\
(0.36)\end{array}$ & $\begin{array}{l}16.78 \\
(0.40)\end{array}$ & $\begin{array}{l}16.78 \\
(0.92)\end{array}$ & $\begin{array}{l}16.36 \\
(0.48)\end{array}$ & $\begin{array}{l}16.64 \\
(054)\end{array}$ & $\begin{array}{l}16.76 \\
(0.35)\end{array}$ & $\begin{array}{l}16.84 \\
(0.54)\end{array}$ & $\begin{array}{l}1687 \\
(0.36)\end{array}$ \\
\hline $\mathrm{Al}_{2} \mathrm{O}_{3}$ & $\begin{array}{l}1.99 \\
(0.16)\end{array}$ & $\begin{array}{l}0.70 \\
(0.11)\end{array}$ & $\begin{array}{l}0.73 \\
(0.10)\end{array}$ & $\begin{array}{l}1.65 \\
(0.19)\end{array}$ & $\begin{array}{l}1.54 \\
(0.24)\end{array}$ & $\begin{array}{l}1.66 \\
(0.12)\end{array}$ & $\begin{array}{l}1.62 \\
(0.16)\end{array}$ & $\begin{array}{l}1.63 \\
(0.19)\end{array}$ & $\begin{array}{l}1.63 \\
(0.22)\end{array}$ \\
\hline $\mathrm{K}_{2} \mathrm{O}$ & $\begin{array}{l}5.15 \\
(0.29)\end{array}$ & $\begin{array}{l}4.34 \\
(0.29)\end{array}$ & $\begin{array}{l}4.39 \\
(0.21)\end{array}$ & $\begin{array}{l}4.38 \\
(0.44)\end{array}$ & $\begin{array}{l}4.50(0 \\
35)\end{array}$ & $\begin{array}{l}4.58 \\
(0.18)\end{array}$ & $\begin{array}{l}3.98(0 \\
31)\end{array}$ & $\begin{array}{l}4.02 \\
(0.22)\end{array}$ & $\begin{array}{l}4.17(0 \\
29)\end{array}$ \\
\hline $\mathrm{Na}_{2} \mathrm{O}$ & $\begin{array}{l}4.20 \\
(0-30)\end{array}$ & $\begin{array}{l}5.66 \\
(0.25)\end{array}$ & $\begin{array}{l}5.63 \\
(0.43)\end{array}$ & $\begin{array}{l}5.51 \\
(0.89)\end{array}$ & $\begin{array}{l}5.43(0 \\
34)\end{array}$ & $\begin{array}{l}5.16 \\
(0.34)\end{array}$ & $\begin{array}{l}5.12 \\
(0.48)\end{array}$ & $\begin{array}{l}5.13 \\
(0.24)\end{array}$ & $\begin{array}{l}5.09(0 \\
35)\end{array}$ \\
\hline $\mathrm{CaO}$ & $\begin{array}{l}2.18 \\
(0.42)\end{array}$ & $\begin{array}{l}4.16 \\
(0.56)\end{array}$ & $\begin{array}{l}3.97 \\
(0.64)\end{array}$ & $\begin{array}{l}1.38 \\
(0.81)\end{array}$ & $\begin{array}{l}3.10 \\
(0.76)\end{array}$ & $\begin{array}{l}2.07 \\
(0.27)\end{array}$ & $\begin{array}{l}0.82(0 \\
21)\end{array}$ & $\begin{array}{l}0.82 \\
(0.19)\end{array}$ & $\begin{array}{l}0.75 \\
(0.36)\end{array}$ \\
\hline $\mathrm{FeO}$ & $\begin{array}{l}0.02 \\
(0.07)\end{array}$ & $\begin{array}{l}0.05 \\
(0.14)\end{array}$ & $\begin{array}{l}0.09 \\
(0.15)\end{array}$ & $\begin{array}{l}0.13 \\
(0.12)\end{array}$ & $\begin{array}{l}0.08 \\
(0.15)\end{array}$ & $\begin{array}{l}0.14 \\
(0.24)\end{array}$ & $\begin{array}{l}0.11 \\
(0.17)\end{array}$ & $\begin{array}{l}0.12 \\
(0.14)\end{array}$ & $\begin{array}{l}0.14 \\
(0.13)\end{array}$ \\
\hline $\mathrm{MnO}$ & $\begin{array}{l}2.53 \\
(0.21)\end{array}$ & $\begin{array}{l}1.87 \\
(0.13)\end{array}$ & $\begin{array}{l}1.88 \\
(0.15)\end{array}$ & $\begin{array}{l}1.31 \\
(1.16)\end{array}$ & $\begin{array}{l}2.01 \\
(0.48)\end{array}$ & $\begin{array}{l}2.30 \\
(0.32)\end{array}$ & $\begin{array}{l}2.57 \\
(0.25)\end{array}$ & $\begin{array}{l}2.59 \\
(0.17)\end{array}$ & $\begin{array}{l}2.49 \\
(0.28)\end{array}$ \\
\hline $\mathrm{TiO}_{2}$ & 0.33 & 0.47 & 0.51 & 0.56 & $0.54(0$ & 0.51 & $0.57(0$ & 0.55 & 0.52 \\
\hline
\end{tabular}




\begin{tabular}{|l|l|l|l|l|l|l|l|l|l|}
\hline Charges & C1A & C2A & C3A & C8A & C1B & C2B & C3B & C4B & C5B \\
\hline & $(012)$ & $(0.14)$ & $($ Oil) & $(0.12)$ & $14)$ & $(0.13)$ & $13)$ & $(0.13)$ & $(0.17)$ \\
\hline $\mathrm{Cr}_{2} \mathrm{O}_{3}$ & $\begin{array}{l}0.01 \\
(0.03)\end{array}$ & $\begin{array}{l}0.01 \\
(0.04)\end{array}$ & $\begin{array}{l}0.02 \\
(0.08)\end{array}$ & $\begin{array}{l}0.01 \\
(0.02)\end{array}$ & $\begin{array}{l}0.04 \\
(0.10)\end{array}$ & $\begin{array}{l}0.03 \\
(0.07)\end{array}$ & $\begin{array}{l}0.03 \\
(0.10)\end{array}$ & $\begin{array}{l}0.04 \\
(0.12)\end{array}$ & $\begin{array}{l}0.04 \\
(0.07)\end{array}$ \\
\hline Total & $\begin{array}{l}89.92 \\
(1.26)\end{array}$ & $\begin{array}{l}88.49 \\
(1.50)\end{array}$ & $\begin{array}{l}89.81 \\
(0.90)\end{array}$ & $\begin{array}{l}88.66 \\
(1.66)\end{array}$ & $\begin{array}{l}90.14 \\
(1.12)\end{array}$ & $\begin{array}{l}90.88 \\
(1.22)\end{array}$ & $\begin{array}{l}90.80 \\
(1.24)\end{array}$ & $\begin{array}{l}91.03 \\
(1.32)\end{array}$ & $\begin{array}{l}91.82 \\
(1.90)\end{array}$ \\
\hline
\end{tabular}

Oxides and totals are in $\mathrm{wt} \%$, with uncertainties presented as twice the standard error of the mean $( \pm 2 \sigma)$ for the replicate measurements. Each probe datum represents the average of the $n$ spot analyses performed in different areas of the corresponding experimental glass. For each charge, concentrations of oxides were normalized to $100 \mathrm{wt} \%$ (i.e., anhydrous) and adjusted to minimize the effect of migration of the alkalis $(\mathrm{Na}, \mathrm{K})$ (see text). Totals are presented before normalization; they are thus relative to the hydrous glasses.

Table 5. Concentrations of major elements (electron microprobe data) in the experimental clinopyroxenes and magnetites for both S-free and S-bearing charges.

\begin{tabular}{|c|c|c|c|c|c|c|c|c|c|c|}
\hline $\begin{array}{l}\text { Charg } \\
\text { e }\end{array}$ & C3A & C1B & C2B & C3B & $\mathbf{C 4 J}$ & $\mathrm{C} 2 \mathrm{~K}$ & C3K & C4K & $\mathrm{C3F}$ & \multirow{2}{*}{$\begin{array}{l}\text { C6J } \\
\begin{array}{l}\text { Magnetite } \\
\text { s }\end{array}\end{array}$} \\
\hline Phases & \multicolumn{9}{|c|}{ Clinopyroxenes } & \\
\hline$n$ & 12 & 14 & 13 & 9 & 25 & 28 & 1 & 13 & 1 & 5 \\
\hline $\mathrm{SiO}_{2}$ & $\begin{array}{l}51.95 \\
(0.99 \\
)\end{array}$ & $\begin{array}{l}54.28 \\
(0.92 \\
)\end{array}$ & $\begin{array}{l}53.79 \\
(0.79 \\
)\end{array}$ & $\begin{array}{l}52.84 \\
(0.96 \\
)\end{array}$ & $\begin{array}{l}51.63 \\
(1.10)\end{array}$ & $\begin{array}{l}53.57 \\
(0.97 \\
)\end{array}$ & 53.51 & $\begin{array}{l}52.67 \\
(0.57 \\
)\end{array}$ & $\begin{array}{l}52.9 \\
4\end{array}$ & $0.14(0.04)$ \\
\hline $\mathrm{Al}_{2} \mathrm{O}_{3}$ & $\begin{array}{l}2.65 \\
(0.76 \\
)\end{array}$ & $\begin{array}{l}1.15 \\
(0.33\end{array}$ & $\begin{array}{l}1.40 \\
(0.51 \\
)\end{array}$ & $\begin{array}{l}2.20 \\
(0.88 \\
)\end{array}$ & $\begin{array}{l}2.53 \\
(0.62)\end{array}$ & $\begin{array}{l}2.88 \\
(1.36 \\
)\end{array}$ & 1.66 & $\begin{array}{l}1.60 \\
(0.22\end{array}$ & 1.08 & $3.76(0.10)$ \\
\hline $\mathrm{K}_{2} \mathrm{O}$ & $\begin{array}{l}0.03 \\
(0.02 \\
)\end{array}$ & $\begin{array}{l}0.04 \\
(0.04 \\
)\end{array}$ & $\begin{array}{l}0.05 \\
(0.04 \\
)\end{array}$ & $\begin{array}{l}0.03 \\
(0.03 \\
)\end{array}$ & $\begin{array}{l}0.04 \\
(0.03)\end{array}$ & $\begin{array}{l}0.14 \\
(0.15 \\
)\end{array}$ & 0.03 & $\begin{array}{l}0.08 \\
(0.05 \\
)\end{array}$ & 0.00 & $0.02(0.02)$ \\
\hline $\mathrm{Na}_{2} \mathrm{O}$ & $\begin{array}{l}0.39 \\
(0.10 \\
)\end{array}$ & $\begin{array}{l}0.36 \\
(0.09 \\
)\end{array}$ & $\begin{array}{l}0.40 \\
(0.12 \\
)\end{array}$ & $\begin{array}{l}0.48 \\
(0.15 \\
)\end{array}$ & $\begin{array}{l}0.54 \\
(0.11)\end{array}$ & $\begin{array}{l}0.48 \\
(0.26 \\
)\end{array}$ & 0.39 & $\begin{array}{l}0.41 \\
(0.07 \\
)\end{array}$ & 0.21 & $0.01(0.03)$ \\
\hline $\mathrm{CaO}$ & $\begin{array}{l}20.15 \\
(0.80 \\
)\end{array}$ & $\begin{array}{l}21.19 \\
(0.56 \\
)\end{array}$ & $\begin{array}{l}20.42 \\
(0.56 \\
)\end{array}$ & $\begin{array}{l}19.45 \\
(0.71 \\
)\end{array}$ & $\begin{array}{l}20.28 \\
(0.65)\end{array}$ & $\begin{array}{l}19.30 \\
(1.13 \\
)\end{array}$ & 21.38 & $\begin{array}{l}20.21 \\
(0.51 \\
)\end{array}$ & $\begin{array}{l}22.5 \\
7\end{array}$ & $0.11(0.06)$ \\
\hline $\mathrm{FeO}$ & $\begin{array}{l}7.00 \\
(0.51\end{array}$ & $\begin{array}{l}3.90 \\
(0.30\end{array}$ & $\begin{array}{l}4.82 \\
(0.45\end{array}$ & $\begin{array}{l}5.82 \\
(0.52\end{array}$ & $\begin{array}{l}4.47 \\
(0.56)\end{array}$ & $\begin{array}{l}5.37 \\
(0.68\end{array}$ & 3.22 & $\begin{array}{l}4.08 \\
(0.30\end{array}$ & 1.14 & $\begin{array}{l}84.05 \\
(0.79)\end{array}$ \\
\hline
\end{tabular}




\begin{tabular}{|c|c|c|c|c|c|c|c|c|c|c|}
\hline $\begin{array}{l}\text { Charg } \\
\text { e }\end{array}$ & C3A & C1B & C2B & C3B & C4J & $\mathrm{C} 2 \mathrm{~K}$ & C3K & C4K & $\mathrm{C} 3 \mathrm{~F}$ & \multirow{3}{*}{$\begin{array}{l}\text { C6J } \\
\begin{array}{l}\text { Magnetite } \\
\text { s }\end{array}\end{array}$} \\
\hline \multirow[t]{2}{*}{ Phases } & \multicolumn{9}{|c|}{ Clinopyroxenes } & \\
\hline & ) & ) & ) & ) & & ) & & ) & & \\
\hline $\mathrm{MnO}$ & $\begin{array}{l}0.31 \\
(0.12 \\
)\end{array}$ & $\begin{array}{l}0.12 \\
(0.08 \\
)\end{array}$ & $\begin{array}{l}0.13 \\
(0.10 \\
)\end{array}$ & $\begin{array}{l}0.17 \\
(0.10 \\
)\end{array}$ & $\begin{array}{l}0.15(0.08 \\
)\end{array}$ & $\begin{array}{l}0.25 \\
(0.11 \\
)\end{array}$ & 0.09 & $\begin{array}{l}0.13 \\
(0.07 \\
)\end{array}$ & 0.13 & $0.13(0.09)$ \\
\hline $\mathrm{MgO}$ & $\begin{array}{l}15.54 \\
(0.95 \\
)\end{array}$ & $\begin{array}{l}16.84 \\
(0.33 \\
)\end{array}$ & $\begin{array}{l}16.93 \\
(0.65 \\
)\end{array}$ & $\begin{array}{l}16.88 \\
(1.07 \\
)\end{array}$ & $\begin{array}{l}18.32 \\
(0.94)\end{array}$ & $\begin{array}{l}17.01 \\
(1.30 \\
)\end{array}$ & 18.02 & $\begin{array}{l}18.25 \\
(0.40 \\
)\end{array}$ & $\begin{array}{l}21.0 \\
1\end{array}$ & $2.81(0.09)$ \\
\hline $\mathrm{TiO}_{2}$ & $\begin{array}{l}0.33 \\
(0.09 \\
)\end{array}$ & $\begin{array}{l}0.13 \\
(0.05 \\
)\end{array}$ & $\begin{array}{l}0.18 \\
(0.06 \\
)\end{array}$ & $\begin{array}{l}0.26 \\
(0.10 \\
)\end{array}$ & $\begin{array}{l}0.22 \\
(0.07)\end{array}$ & $\begin{array}{l}0.32 \\
(0.08 \\
)\end{array}$ & 0.32 & $\begin{array}{l}0.16 \\
(0.05 \\
)\end{array}$ & 0.24 & $1.68(0.05)$ \\
\hline $\mathrm{Cr}_{2} \mathrm{O}_{3}$ & $\begin{array}{l}0.31 \\
(0.22 \\
)\end{array}$ & $\begin{array}{l}0.85 \\
(0.25 \\
)\end{array}$ & $\begin{array}{l}0.76 \\
(0.22 \\
)\end{array}$ & $\begin{array}{l}0.55 \\
(0.22 \\
)\end{array}$ & $\begin{array}{l}0.88 \\
(0.31)\end{array}$ & $\begin{array}{l}0.26 \\
(0.11 \\
)\end{array}$ & 1.40 & $\begin{array}{l}0.99 \\
(0.11 \\
)\end{array}$ & & $0.48(0.17)$ \\
\hline Total & $\begin{array}{l}98.66 \\
(0.78 \\
)\end{array}$ & $\begin{array}{l}98.86 \\
(0.71 \\
)\end{array}$ & $\begin{array}{l}98.87 \\
(0.69 \\
)\end{array}$ & $\begin{array}{l}98.69 \\
(0.42 \\
)\end{array}$ & $\begin{array}{l}99.05 \\
(0.61)\end{array}$ & $\begin{array}{l}99.59 \\
(0.69 \\
)\end{array}$ & $\begin{array}{l}100.0 \\
0\end{array}$ & $\begin{array}{l}98.58 \\
(0.41 \\
)\end{array}$ & $\begin{array}{l}99.3 \\
2\end{array}$ & $\begin{array}{l}93.20 \\
(0.76)\end{array}$ \\
\hline Wo\% & 42.44 & 44.37 & 42.68 & 40.85 & 41.07 & 40.75 & 43.60 & 41.34 & $\begin{array}{l}42.7 \\
4\end{array}$ & \\
\hline En\% & 45.54 & 49.06 & 49.24 & 49.33 & 51.62 & 49.98 & 51.13 & 51.94 & $\begin{array}{l}55.3 \\
8\end{array}$ & - \\
\hline $\mathrm{Fs} \%$ & 12.02 & 6.57 & 8.08 & 9.82 & 7.31 & 9.27 & 5.27 & 6.72 & 1.87 & - \\
\hline $\mathrm{Mg \#}$ & 79.83 & 88.50 & 86.23 & 83.79 & 87.96 & 84.95 & 90.89 & 88.86 & $\begin{array}{l}97.0 \\
6\end{array}$ & - \\
\hline
\end{tabular}

Oxides and totals are in $\mathrm{wt} \%$, with uncertainties presented as twice the standard error of the mean $( \pm 2 \sigma)$ for the replicate measurements. Each probe datum represents the average of the $n$ spot analyses performed in different crystals of the corresponding experimental mineral phase (except for charges $\mathrm{C} 3 \mathrm{~K}$ and $\mathrm{C} 3 \mathrm{~F}$ where only one crystal was large enough to br analysed).

For each charge, the proportions of pure wollastonite (Wo), enstatite (En) and ferrosillite (Fs) were calculated from the structural formula of the average clinopyroxene (considering $\mathrm{FeO}=\mathrm{FeO}$ total $)$, together with the corresponding $\mathrm{Mg} \#(=100 \times[\mathrm{Mg}] /([\mathrm{Mg}]+[\mathrm{Fe}]))$. Among charges containing magnetites (run no. 10; see text), only C6J displayed crystals large enough to be analysed. 
Table 6. Compositions of pyrrhotites S-bearing charges and estimates of $f \mathrm{~S}_{2}$.

\begin{tabular}{|l|l|l|l|l|}
\hline Charge & C2E & C1F & C2F & C3F \\
\hline$n$ & 5 & 5 & 5 & 5 \\
\hline $\mathrm{Fe}$ & $59.67(0.29)$ & $59.65(0.51)$ & $60.29(0.48)$ & $60.18(0.35)$ \\
\hline $\mathrm{S}$ & $39.37(0.26)$ & $40.72(0.60)$ & $40.90(0.38)$ & $40.73(0.21)$ \\
\hline $\mathrm{O}$ & $0.04(0.05)$ & $0.13(0.18)$ & $0.03(0.05)$ & $0.05(0.07)$ \\
\hline Total & $99.09(0.37)$ & $100.50(0.87)$ & $101.22(0.62)$ & $100.96(0.27)$ \\
\hline $\mathrm{NFeS}$ & 0.931 & 0.914 & 0.917 & 0.918 \\
\hline $\mathrm{XFeS}$ & 0.870 & 0.841 & 0.846 & 0.848 \\
\hline $\log f \mathrm{~S}_{2}$ & 1.15 & 2.03 & 1.88 & 1.82 \\
\hline
\end{tabular}

Concentrations of $\mathrm{Fe}, \mathrm{S}$ and $\mathrm{O}$ are in $\mathrm{wt} \%$, with uncertainties presented as once the standard error of the mean $( \pm \sigma)$ for the replicate measurements. Each probe datum represents the average of the $n$ spot analyses performed in different crystals of pyrrhotites. In the run no. 5 , only the charge $\mathrm{C} 2 \mathrm{E}$ displayed crystals large enough to be analyzed. Molar fractions of $\mathrm{FeS}$ in $\mathrm{FeS}_{\mathrm{S}} \mathrm{S}_{2}$ and FeS-S systems, respectively, NFeS and $\mathrm{XFeS}$, as well as the method of $f \mathrm{~S}_{2}$ from XFeS, are taken from Froese and Gunter (1976). 


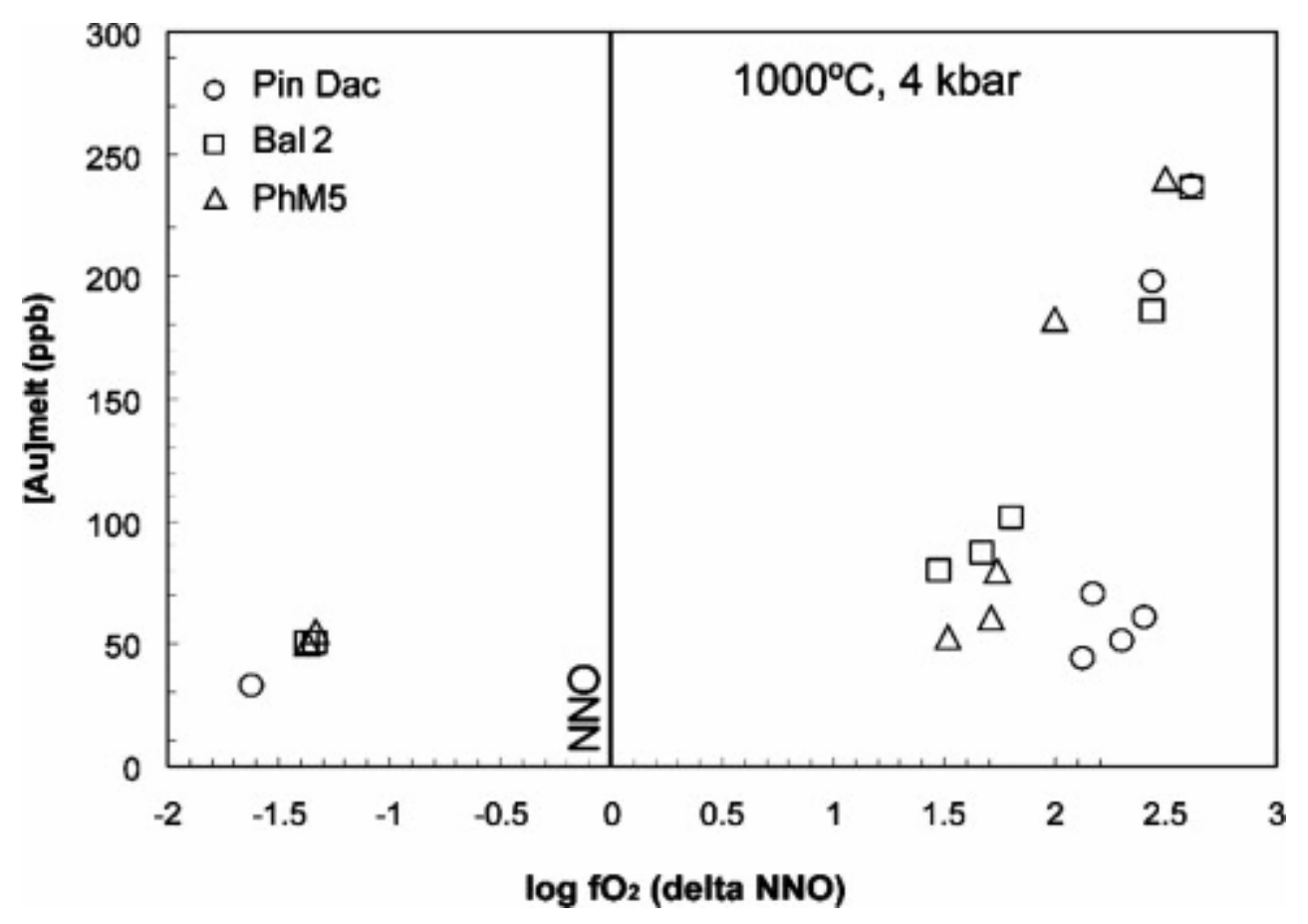

Fig. 4.

Concentration of gold in experimental glasses as a function of $f \mathrm{O}_{2}$ at $1000{ }^{\circ} \mathrm{C}$ and $4 \mathrm{kbar}$ for the S-free PhM5, Bal2 and Pin Dac compositions. Au concentrations expressed in ppb. The NNO buffer is shown for reference. 


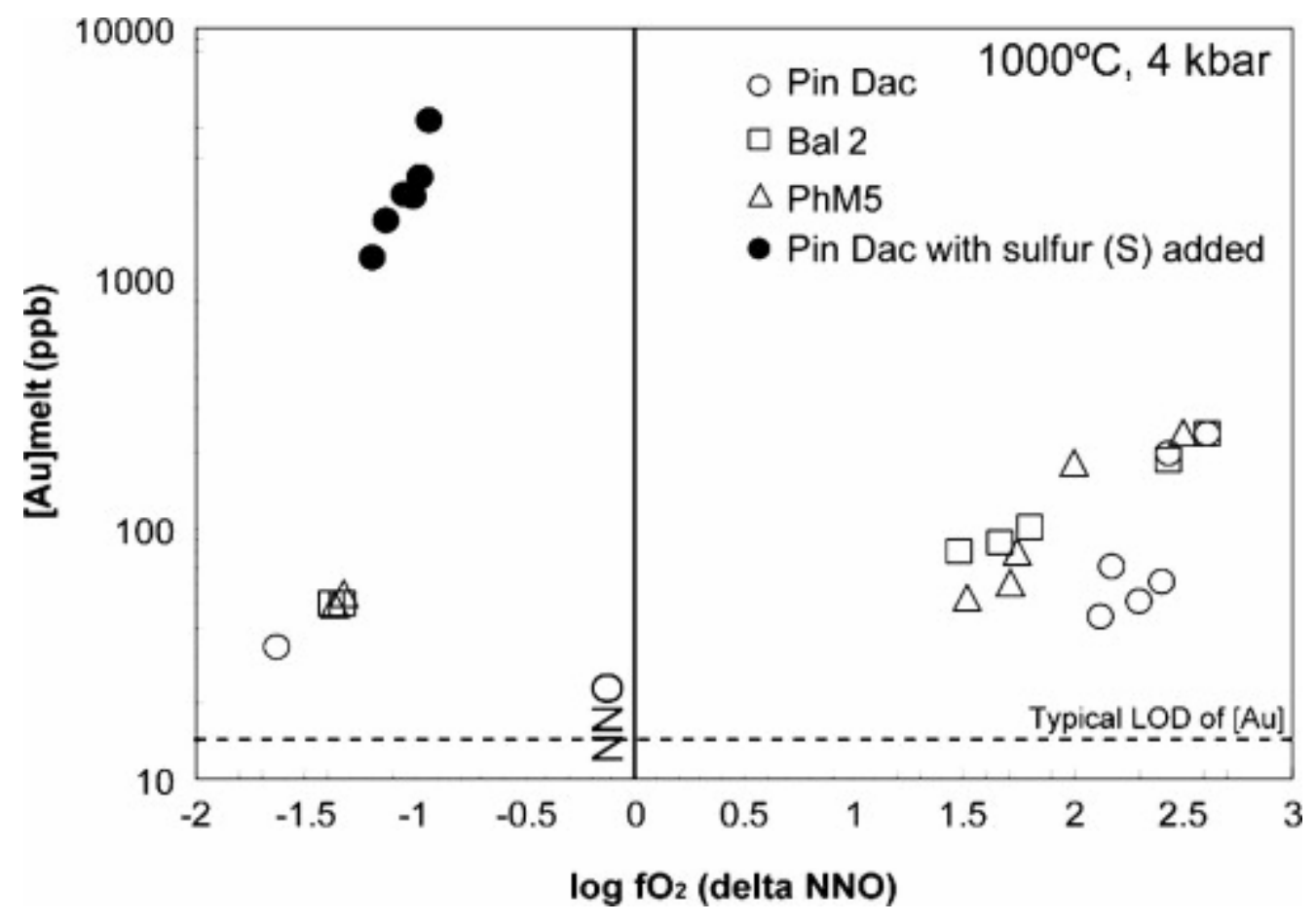

Fig. 5.

Concentration of gold in experimental glasses as a function of $f \mathrm{O}_{2}$ at $1000{ }^{\circ} \mathrm{C}$ and $4 \mathrm{kbar}$ for the S-bearing Pin Dac composition (filled symbols), and comparison with gold concentrations for the S-free PhM5, Bal2 and Pin Dac compositions (open symbols). Au concentrations expressed in ppb. The NNO buffer and the typical limit of detection for gold are indicated. 


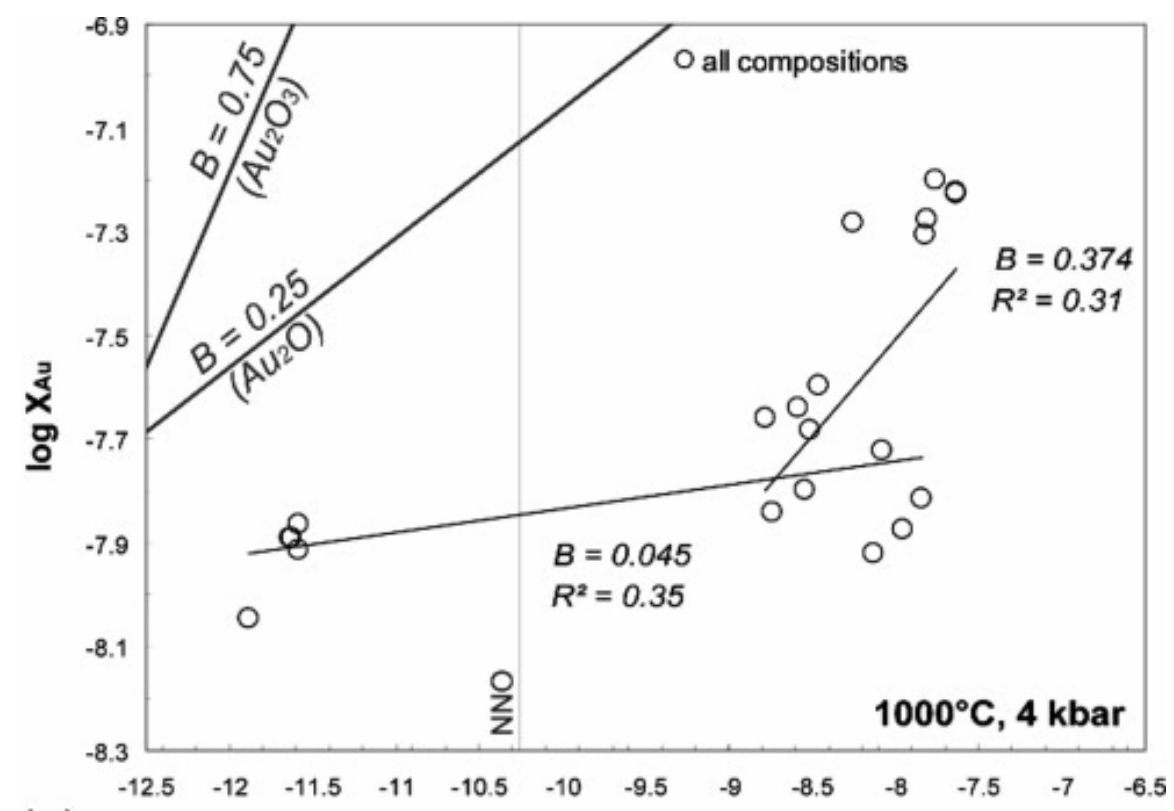

(a)

$\log \mathrm{fO}_{2}$

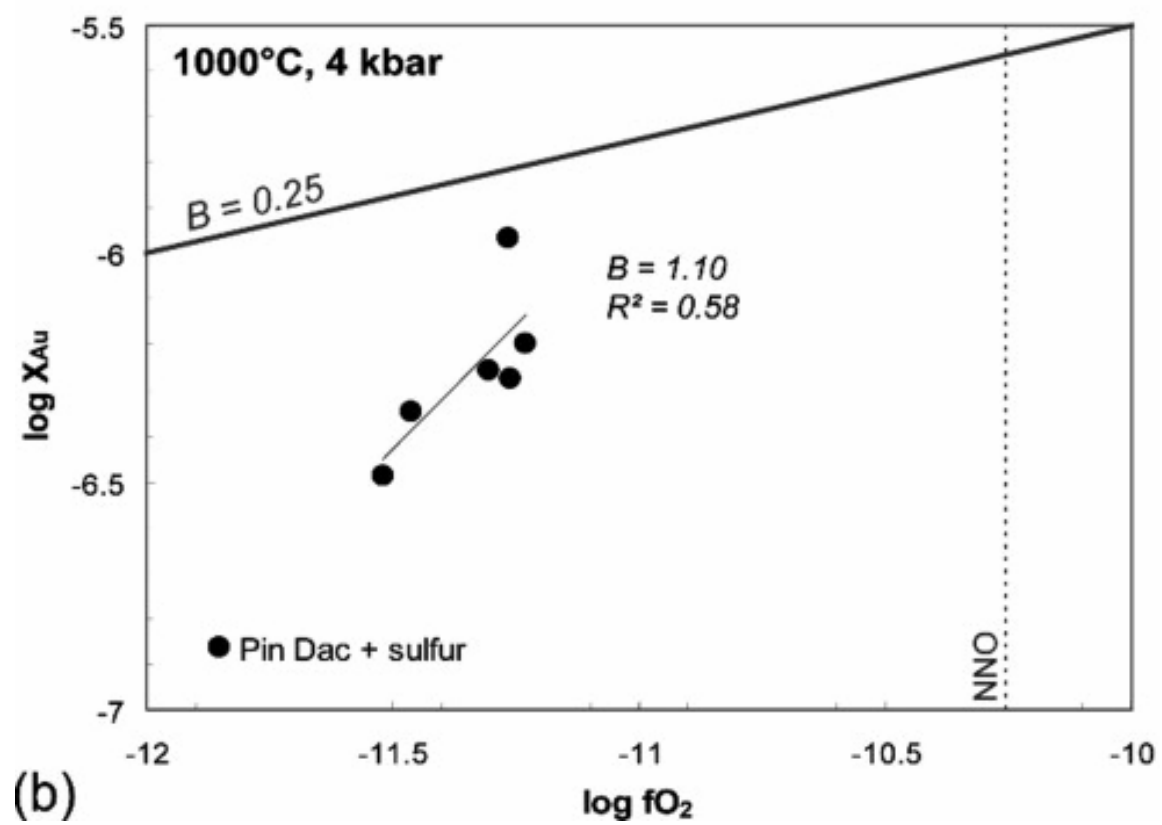

Fig. 6.

Concentration of gold in experimental glasses as a function of $f \mathrm{O}_{2}$ at $1000{ }^{\circ} \mathrm{C}$ and $4 \mathrm{kbar}$ for (a) S-free charges of the PhM5, Bal2 and Pin Dac compositions and (b) S-bearing charges of the Pin Dac composition. The NNO buffer is shown for reference on both diagrams. Au concentrations are expressed in mole fractions. The lines drawn in (a) and (b) are linear fits to the variations of $\mathrm{Au}$ concentration with $f \mathrm{O}_{2}$, based on Eq. (6). $\mathrm{B}$ is the slope of the regression line hence, from Eq. (6), $\mathrm{B}=\mathrm{x} / 4 . R^{2}$ is the coefficient of regression of the data. In (a), the linear regressions are calculated for all compositions taken together. The data were fitted by dividing the $f \mathrm{O}_{2}$ range into two parts: $\mathrm{NNO}-1.4$ to $\mathrm{NNO}+1.8(B=0.045)$ and NNO+1.5 to $\mathrm{NNO}+2.6(B=0.374)$. The lines of slope $1 / 4(B=0.25, x=1)$ and $3 / 4(B=0.75, x=3)$ are shown for reference, to indicate gold dissolution mechanism controlled by species $\mathrm{Au}_{2} \mathrm{O}$ (Borisov and Palme, 1996) and $\mathrm{Au}_{2} \mathrm{O}_{3}$. In (b), the linear regression is shown for reference, since $f \mathrm{~S}_{2}$ varies along with $f \mathrm{O}_{2}$ for the plotted charges so that the changes in Au solubility are not controlled only by $f \mathrm{O}_{2}$. 


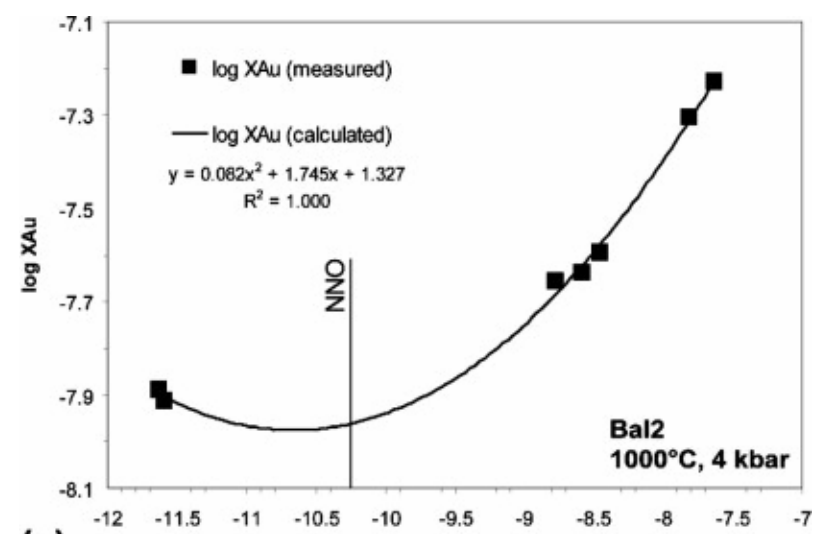

(a)

$\log \mathrm{fO}_{2}$

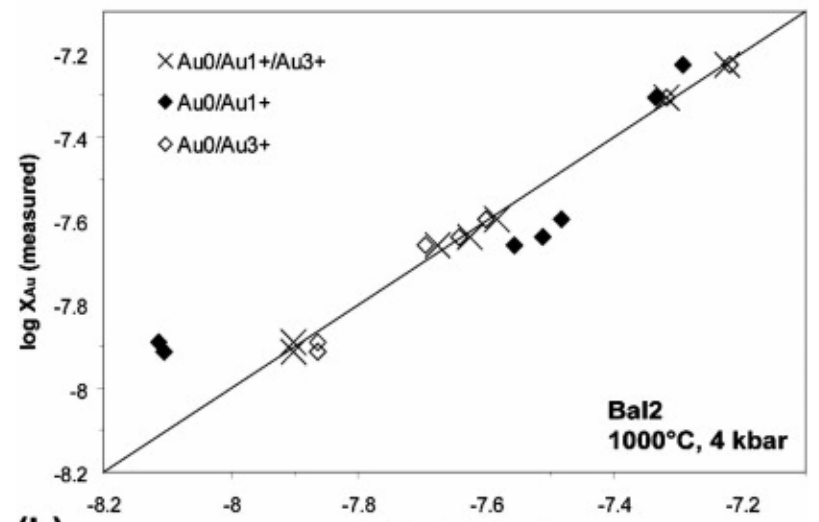

(b)

$\log X_{\text {Au }}$ (calculated)

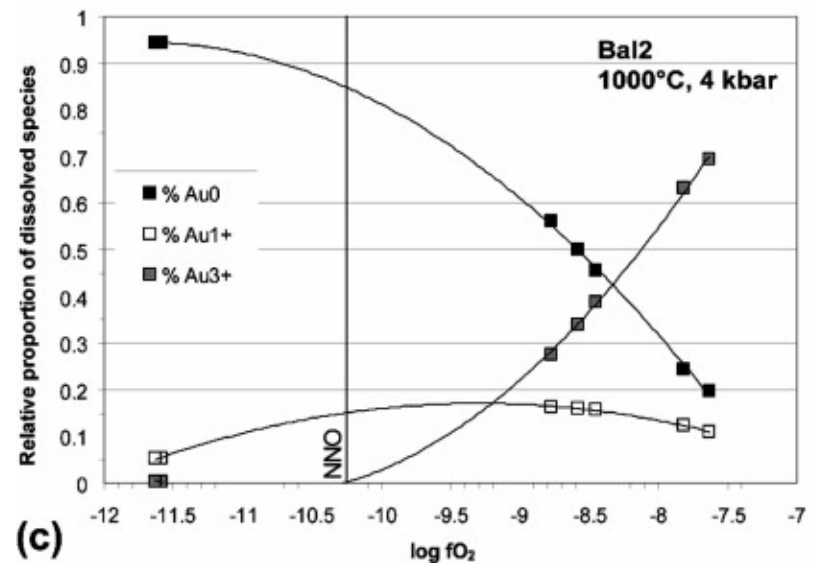

Fig. 7.

Results of the Au solubility model for Bal 2 melt composition at $1000{ }^{\circ} \mathrm{C}, 4$ kbar. (a) Dependence of $\mathrm{Au}$ solubility with $\mathrm{fO}_{2}$. The NNO buffer is shown for reference. The model here considers a combination of $\mathrm{Au}^{0}, \mathrm{Au}^{1+}$ and $\mathrm{Au}^{3+}$ gold species. See text for more details. Note the close agreement between model and experimental data, and the presence of a $\mathrm{Au}$ solubility minimum near NNO. (b) Comparison between calculated and measured $\mathrm{Au}$ concentrations in melt using different models with multiple gold species. The best agreement is found for the three species model; various two species models yield less satisfactory results. (c) Change of the relative proportions of the different Au species with $f \mathrm{O}_{2}$. The model considered here is the three species model. Notice the symmetrical evolution of the proportions of the $\mathrm{Au}^{0}$ and $\mathrm{Au}^{3+}$ gold species, and the small variation in the proportion of $\mathrm{Au}^{1+}$ species across the entire $\mathrm{fO}_{2}$ range. 


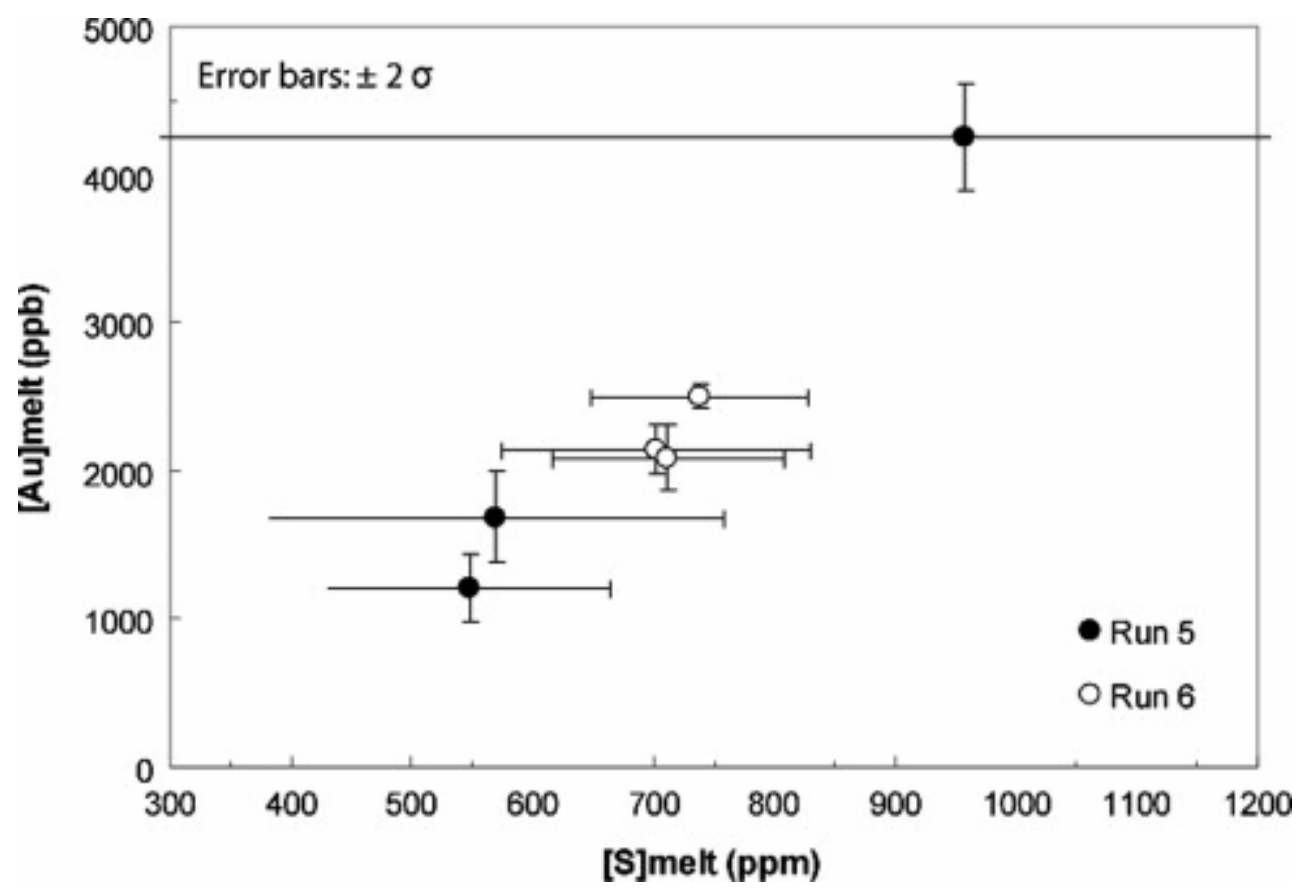

Fig. 8.

Concentration of gold (in ppb) in S-bearing Pin Dac experimental glasses as a function of melt sulfur content (in ppm) at $1000{ }^{\circ} \mathrm{C}$ and $4 \mathrm{kbar}$. Error bars stand for twice the standard error of the mean $( \pm 2 \sigma$; see Table 3$)$. 